\title{
تصور مقترح لإدارة الأندية الرياضية بنظام الخصخصة الجزئية بمحافظة أسوان
}

* أ. دـ/عادل محمد عبد المنعم مكي

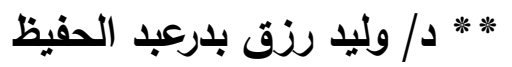

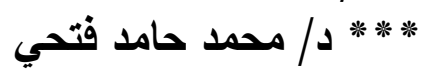

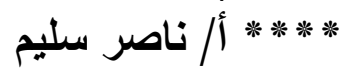

المقدمة ومشكلة البحث :

يعيش العـالم في السنوات الأخيرة عصـرا جديدا يحفل بالعديد من المتغيرات والتحديات

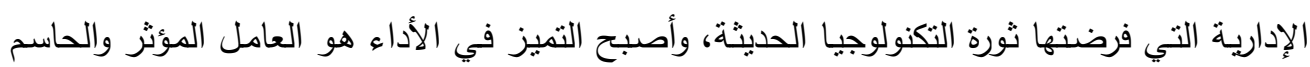

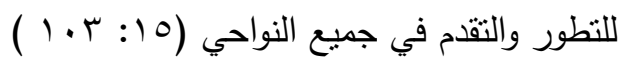
وكان من الطبيعي أن تظهر آليات ومفاهيم جديدة في عالمي الم الإدارة تبرز أهميـة المتغير كعامل رئيسي ومؤثر لتحقيق الاستخدام الأمثل للموارد البشرية والمادية

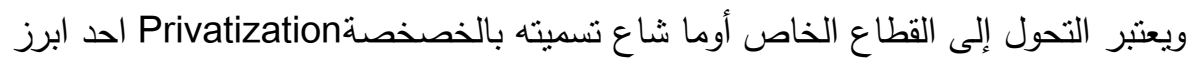

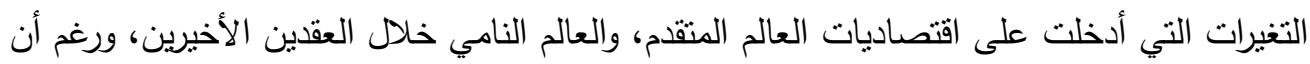

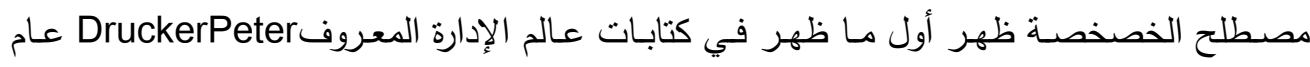
1971، إإلا انه اكتسب أهيته بعدما قامت حكومـة المحافظين في بريطانيا بقيادة مارجريت تاتتـر

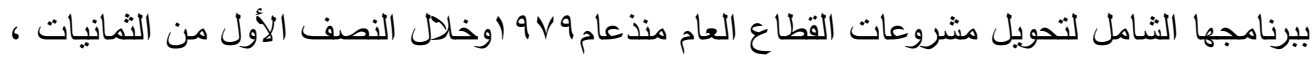

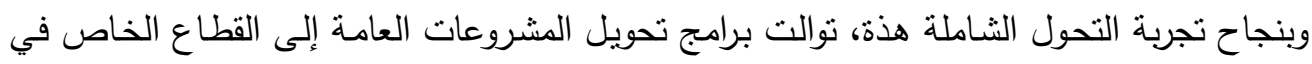

$$
\text { مختلف الدول .(10: } 90 \text { ) }
$$

وخلال العامين الأخيرين اتخذ عدد من البلاد العربية إجراءات تحويل مشروعات عامة إلى إهى

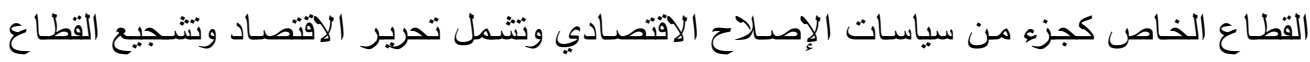

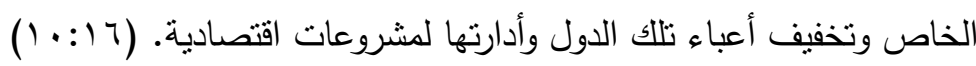

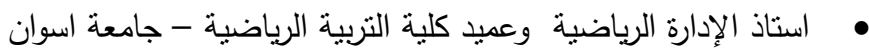

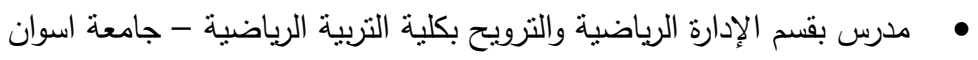
• • • • • • • • مدير عام مدرس بع 
ورغم الجدل الذي إثارته هذه السياسات خلال الثمانينات،إلا أن التجارب المتلاحقة لنطبيقها

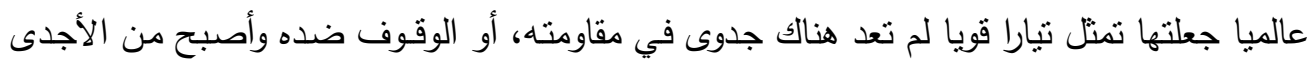

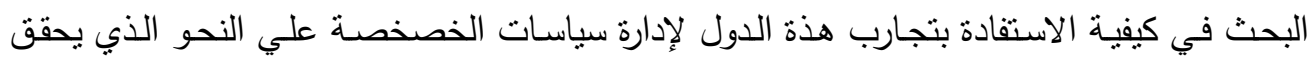

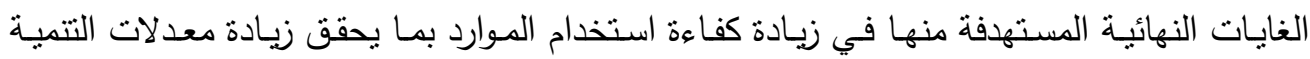

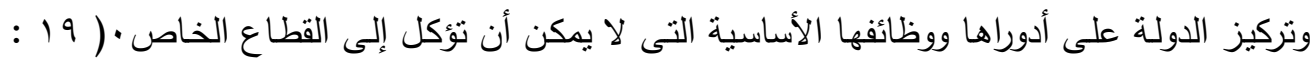

ولجأت مصر إلى الخصخصـة كجزء من سياسـة قوميـة متكاملـة تهدف إلى إصـلاح

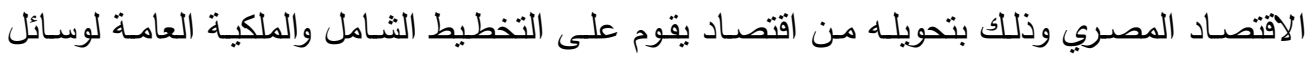

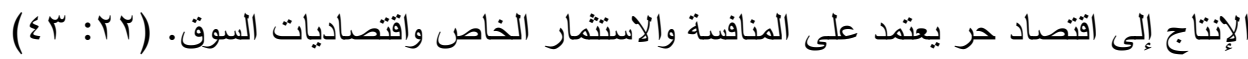

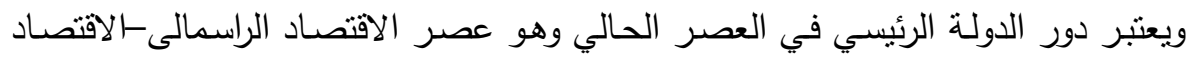

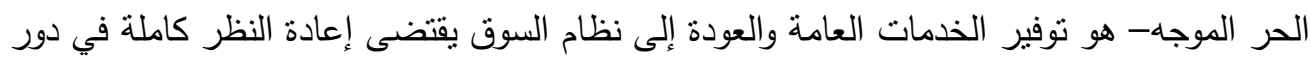

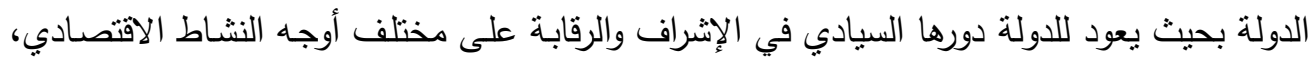

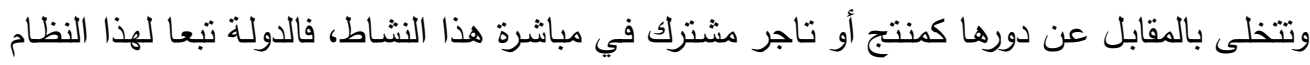
ليست طرفا في ممارسـة النشاط الاقتصادي بقدر ما هي الحكم الذي يضع قواعد وشروط مباشرة

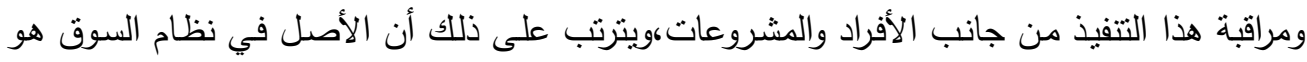

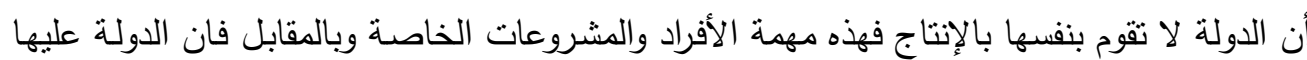

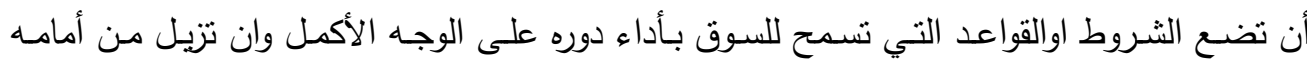

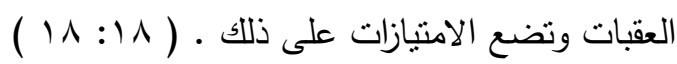

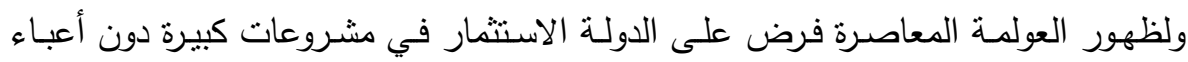

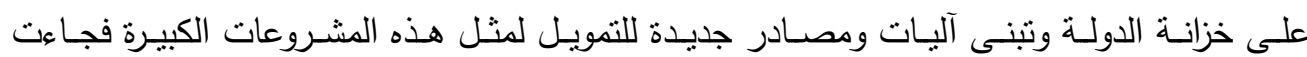

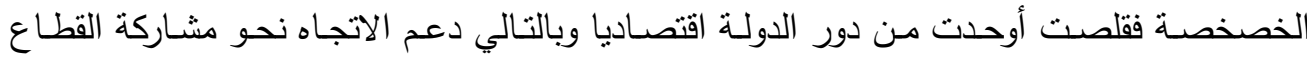

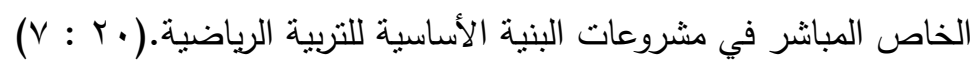

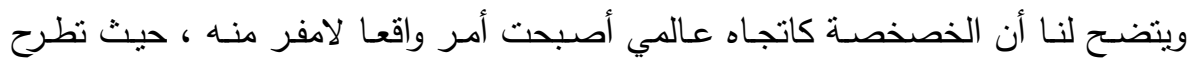

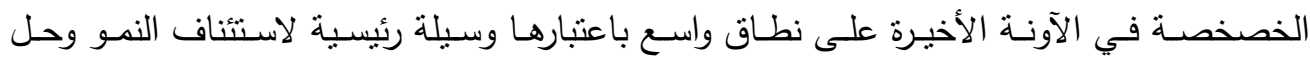

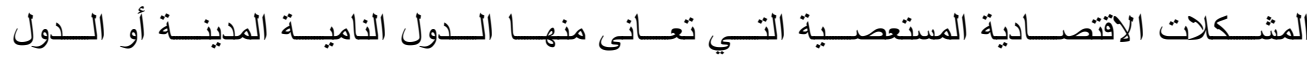

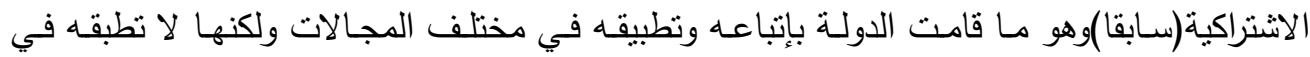

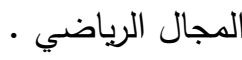


فقد كانت ومازالت الدولة هي الركيزة الأساسية بالرغم من المشروعات الاستثمارية التي

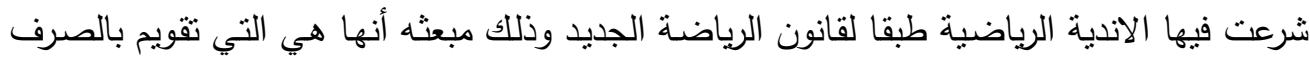

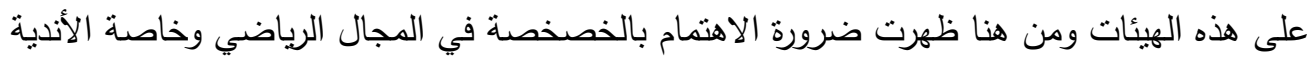

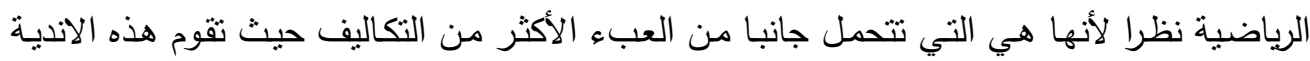

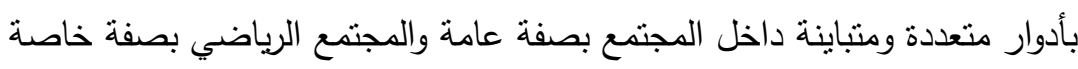

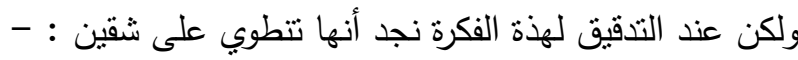

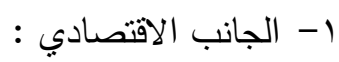

أي الفوائد الاقتصادية التي ستعود على هذه الاندية من خلال تطبيق الخصخصة وكذلك الفوائد الني ستعود على الدولة من خفض الموازنات المرتبطة بهذا الجانب وكذلك الفوائد التي ستعود التئل

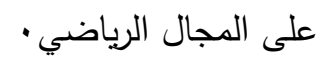

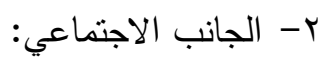

هـي أن الدولـة في الأصـل أقامت هذه الانديـة لتقوم بوظيفيـة اجتماعيـة موازيـة للوظيفـة

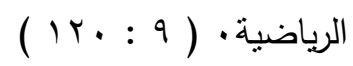

حيث تعتبر الانديـة الرياضية مراكز إثـعاع تستهدف نشـر واستيعاب مختلف الأنشطة

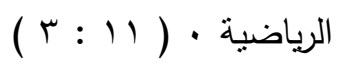

وتأتى الخصخصـة في مصر بغرض إفساح المجال أمام الدور التنموي للقطاع الخاص

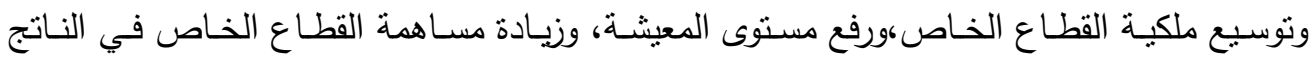

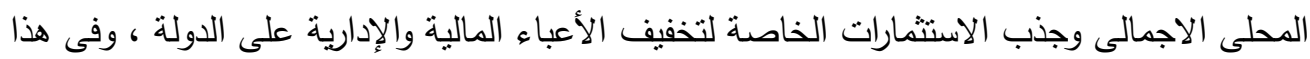

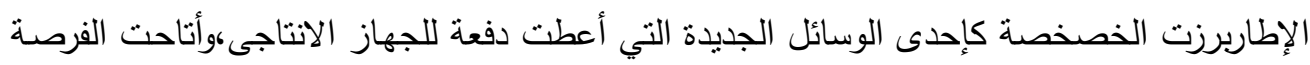

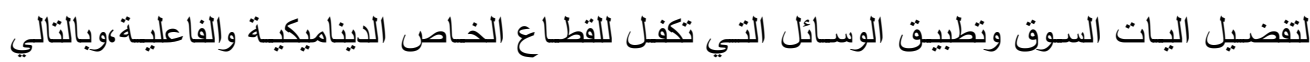
أصبحت الخصخصة أحدى أدوات السياسة الاقتصادية في معظم دول العالم وان اختلفت في دراجات

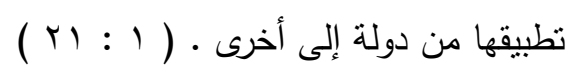

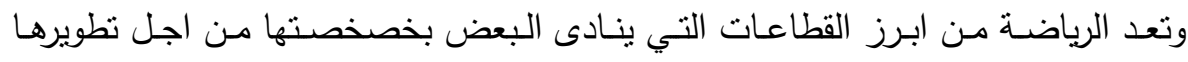

$$
\text { والاستفادة من مكاسبها،وخاصة أنها قطاع مربح اقتصاديا بالفعل. (09: 1 ) ) }
$$

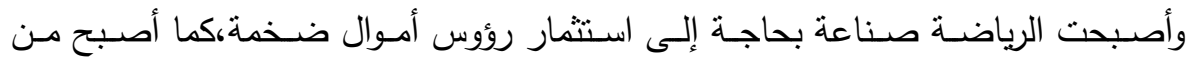
المتعزر على الصحافة الرياضية تغطية فعاليات الحياة الرياضية بمعزل عن أساسها المادي وبنيتها رونها 
التحنية،وفى بعض الأنظمة تحولت الرياضـة إلى تجارة،وبتعبير أدق أصبح للرياضة جانبها التجاري

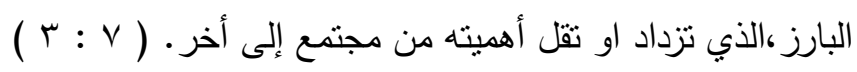

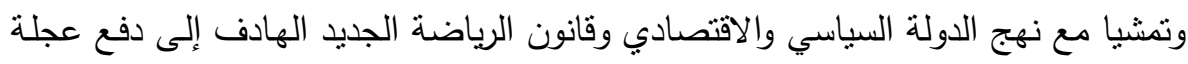

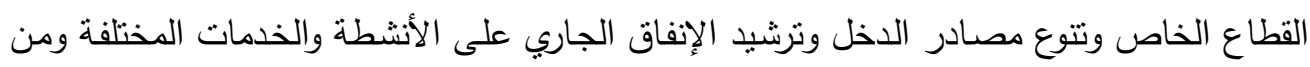

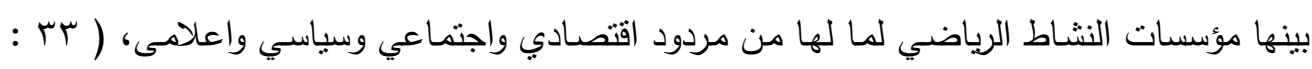

ويؤكد كل من مصطفى حسين باهى، محمد متولي عفيفي أن المنظمات التي تهنت

بالأنشطة الرياضية تحتاج جميعها إلى مصدرين أساسين في العملية الإدارية هما المصادر البشرية

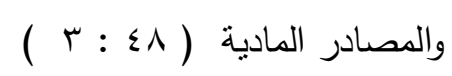

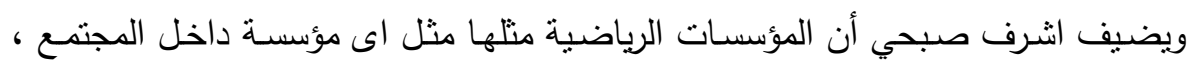

وذلك من حيث الهيكلة والبناء فالمؤسسة الرياضية لا تختلف عن المؤسسات الأخرى •( ^ : . ب )

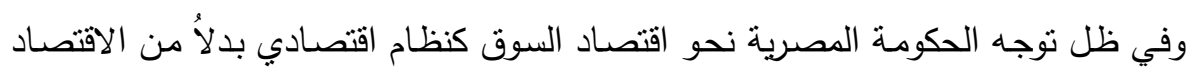

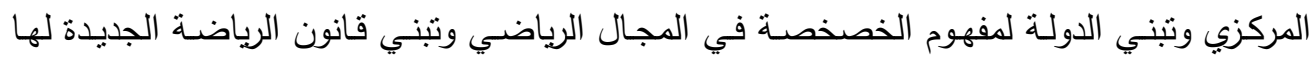

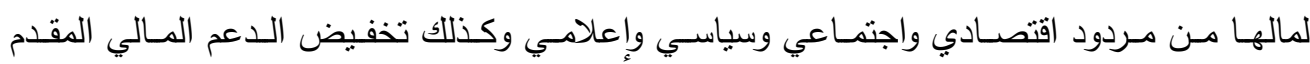

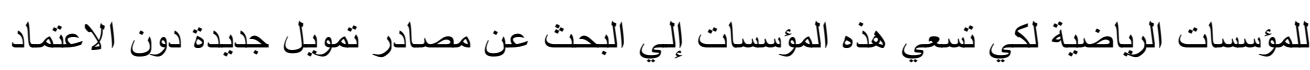

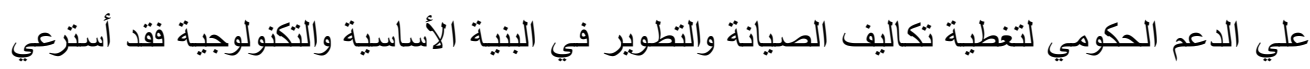

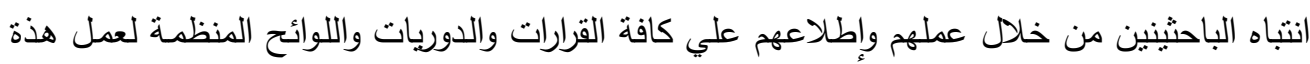

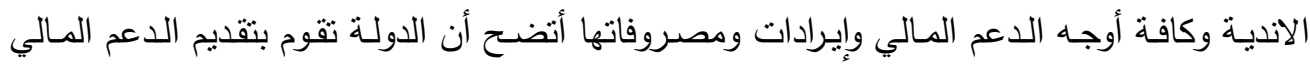

$$
\begin{aligned}
& \text { السنوي لهذه المؤسسات الهات الهات } \\
& \text { هاف البحث }
\end{aligned}
$$

يهدف البحث إلى وضع تصور مقترح لإدارة الأندية الرياضية بنظام الخصخصـة الجزئية

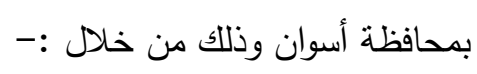

ا. التعرف على الوضع الحالي لإدارة الاندية الرياضية بمحافظة أسوان

r. وضع تصور مقترح لإدارة الاندية الرياضية بنظام الخصخصة الجزئية بمحافظة أسوان

\section{تساؤلات البحث}

1. ما الوضع الحالي لإدارة الاندية الرياضية بمحافظة أسوان ؟

r. ما التصور المقترح لإدارة الاندية الرياضية بنظام الخصخصة الجزئية بمحافظة أسوان؟ 


\section{المصطلحات الواردة في البحث}

الأندية الرياضية

النادي هو "هيئة أهلية تثبت لها الثخصية الاعتبارية بمجرد شهر نظامها علي وفق احكام

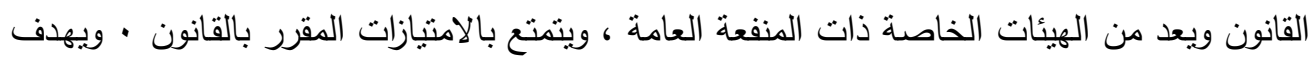
الي تكوين الثخصية المتكاملة للأعضاء من النواحي الوطنية والرياضية والثقافية والاجتماعية وغيرها عن طريق ممارسة الرياضة وتتمية ملكاتهم المختلفة " .

الخصخصة الجزئية

وهي خصخصة الإدارة دون الأصول وتتكون من عدة طرق وهي :- الجصنة

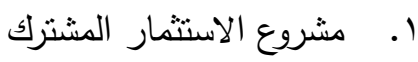

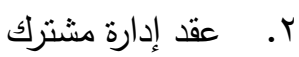

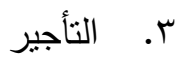

ع. أسلوب البناء والتملك والتشغيل ونقل الملكية BOOT

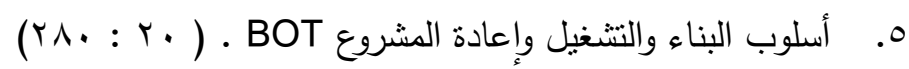

الاراسات السابقة

الدراسات العربية

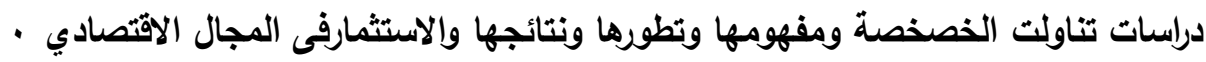

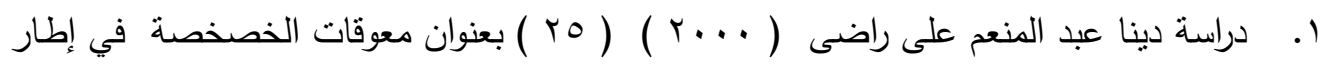

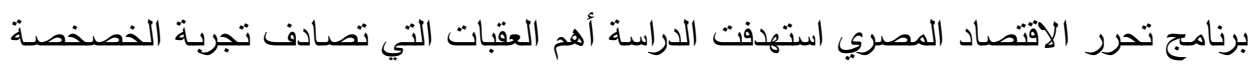

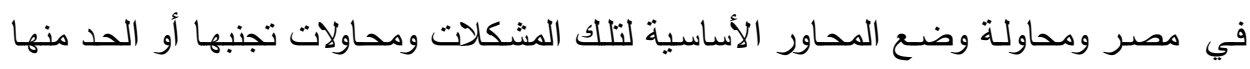
وكيف واجهت التجربة المصرية هذة العقبات واستخدمت الباحثينة المنهج الاسئقرائى والتاريخي

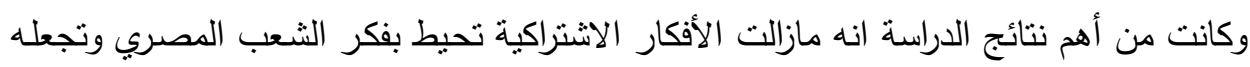

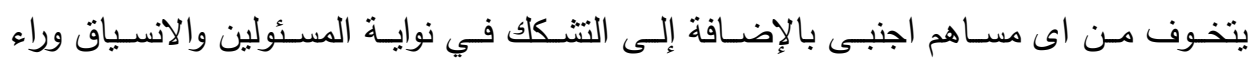
الثائعات وضعف الخبرة والثقافة الاقتصادية .

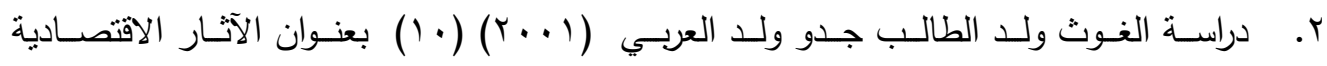

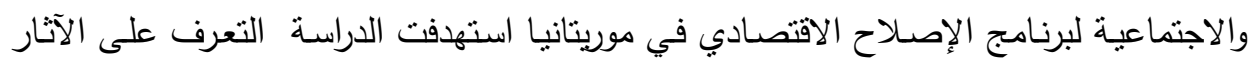

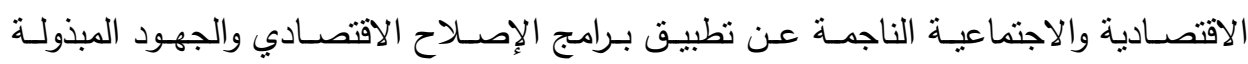

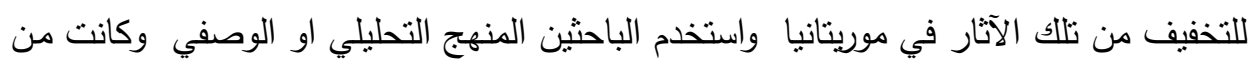




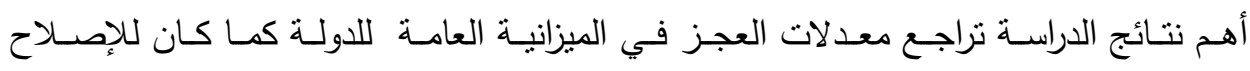
الاقتصادي ثأثثر مباشر على حياه السكان وخاصة المناطق المحدودة والمنوسطة الدخل .

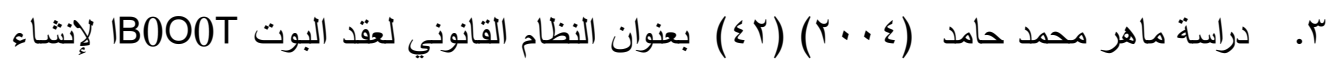
والتملك والتتغيل ونقل الملكية وكان هدف الدراسة إتباع منهج تاصيلى وتحليلي لتحليل المسائل التي يثيرها التعاقد بنظام البوت B0O0T وردها إلى القواعد التي تحكمها في القانون الخاص

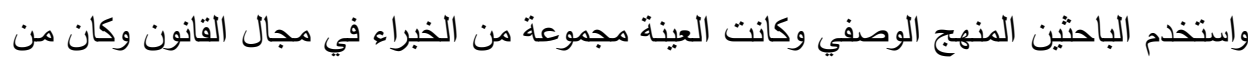
نتائج الدراسة وضع بعض القواعد التي تحكم العقد بنظام البوت . دراسات تناولت الخصخصة في قطاعات مختلفة .

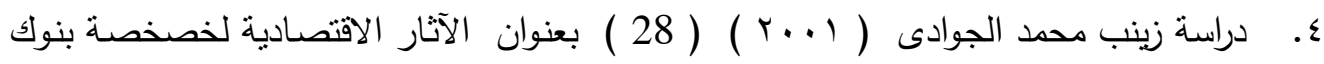

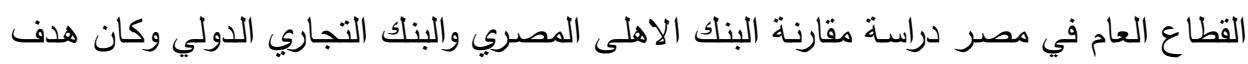
الدراسة معرفة اثر عملية الخصخصة على كفاءة العمل المصرفي في مصر في ظل المنافسة

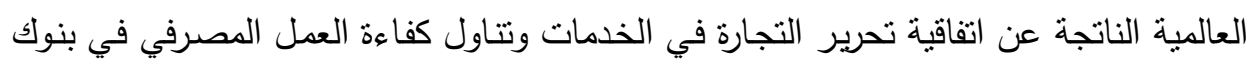

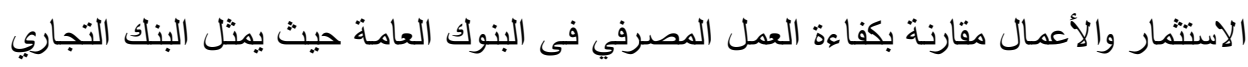

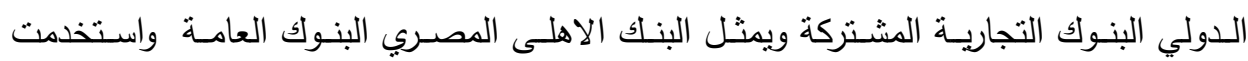

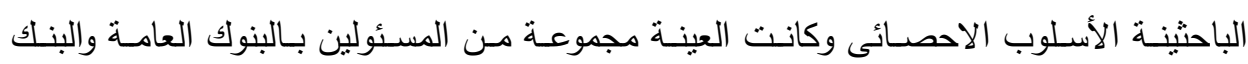

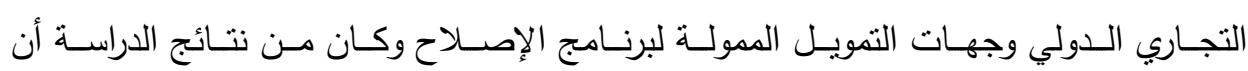

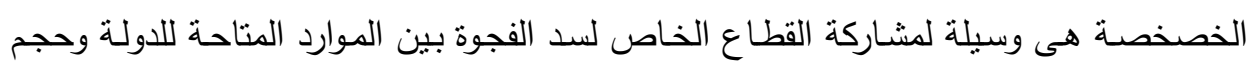
الاستثمارات المطلوبة لتحقيق التتمية المستهدفة وانخفاض مؤثرات ربحية القطاع العام التجارية

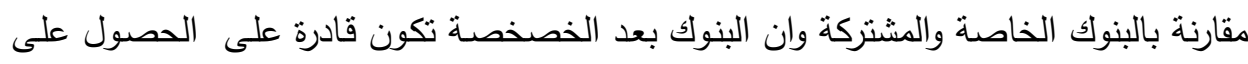

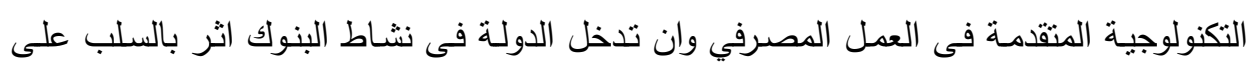
- المنافسة بينها

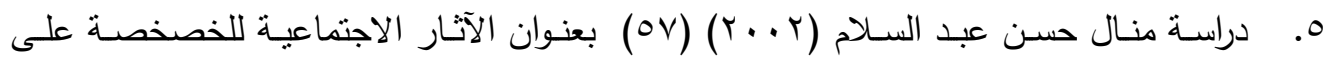

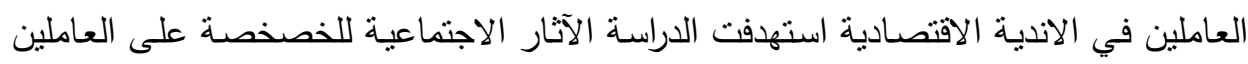

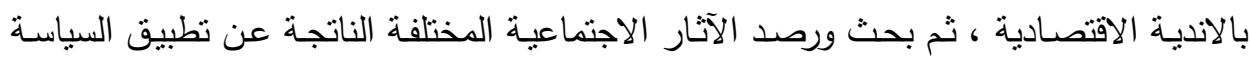
الاقتصادية الجديدة المعروفة باسم " الخصخصة " والتي ينادى العالم كله بنطبيقها ألان، وكذلك

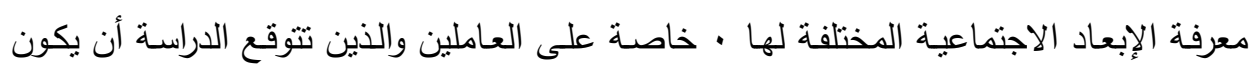


تأثيرهم بها اثد من غيرهم من الجماعات الأخرى لأنهم يدخلون في عداد الجماعات الضعيفة

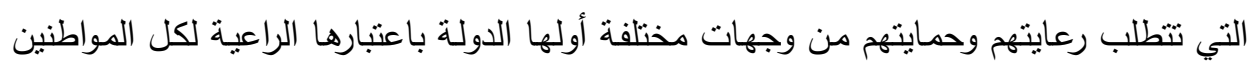

وبخاصة هولاء العمال باعتبارهم عصب العملية الإنتاجية .

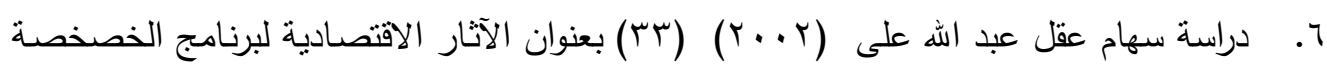

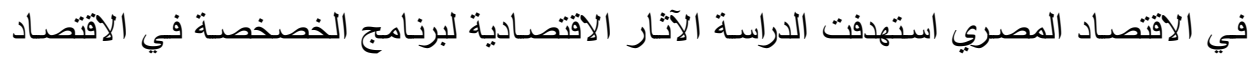

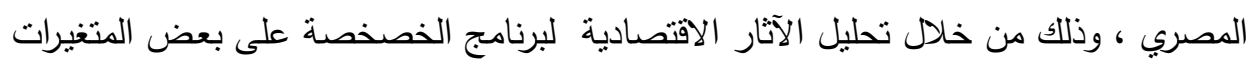

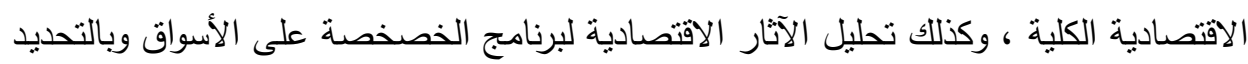

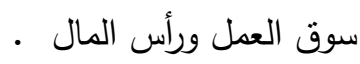
دراسات تناولت الخصخصة في المجال الرياضي

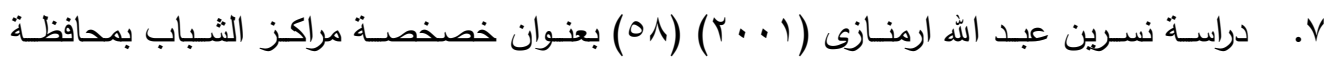
الإسكندرية إستراتيجية مقترحة استهدفت الدراسة خصخصة مراكز الثباب بمحافظة الإسكندرية

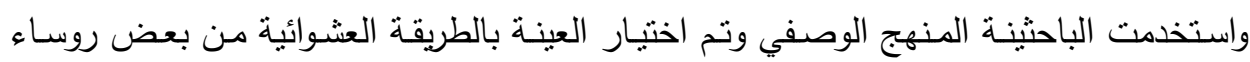

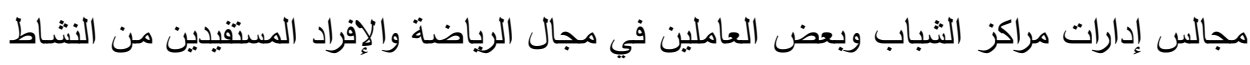

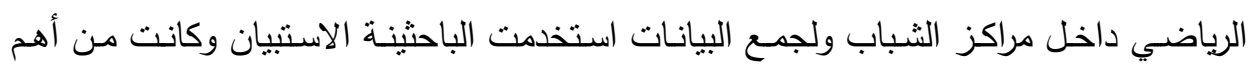
نتائج الدراسة أن هناك قصور فى العمليات الإدارية ومساهمة رجال الإعمال في ملكية مراكز

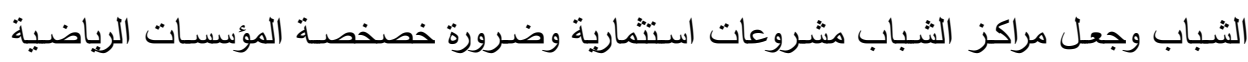

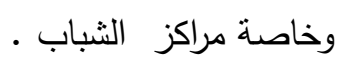

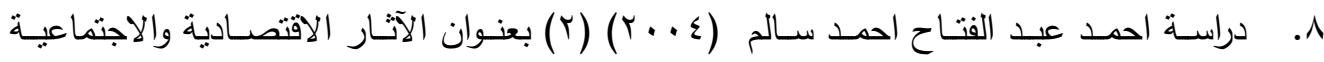

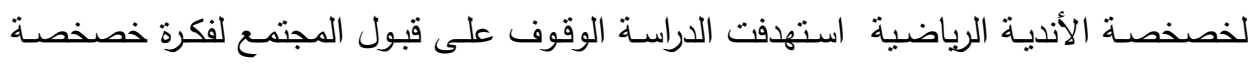

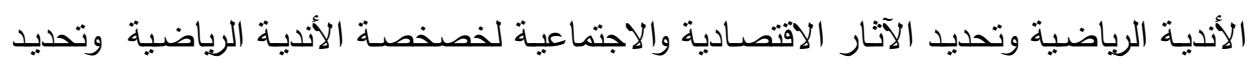

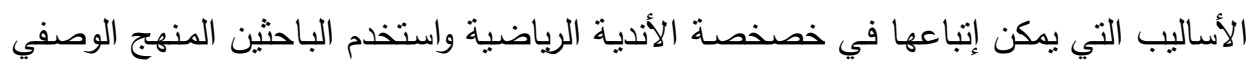

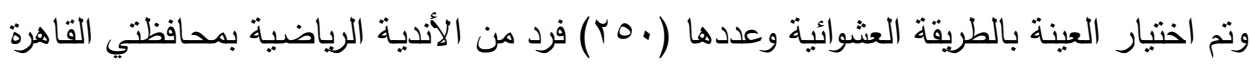

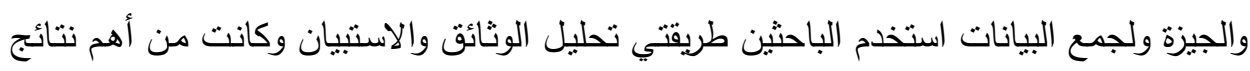
الدراسة الموافقة على خصخصة الأندية الرياضية والتعرف على الآثار الاقتصادية والاجتماعية

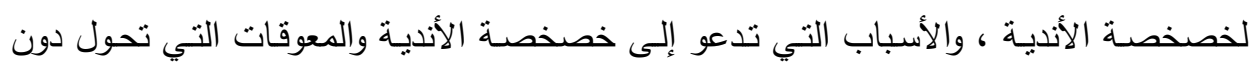
تطبيق فكرة الخصخصة لهذه الأندية . 


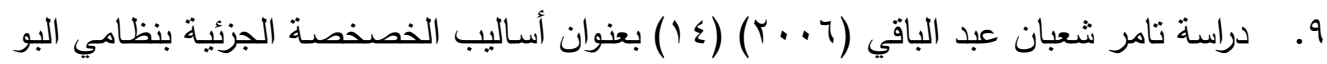

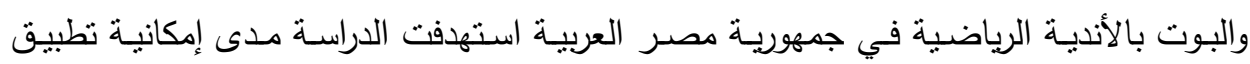

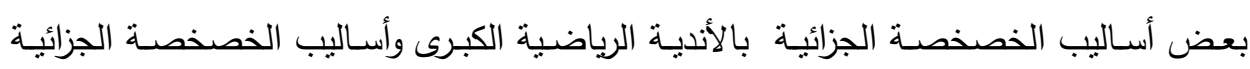

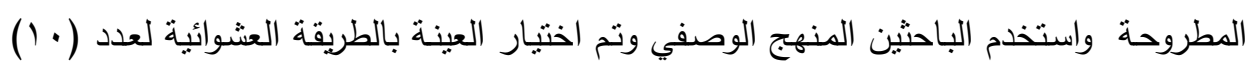

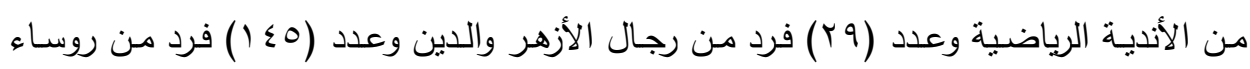
الأندية والأعضاء ولجمع البيانات استخدم الباحثين طريقتي المقابلة والاستبيان وكانت من أهم الهم

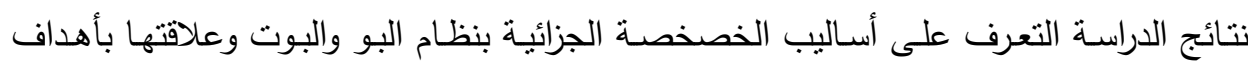

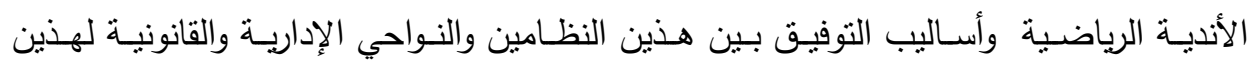

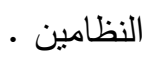

\section{الاراسات الأجنبية}

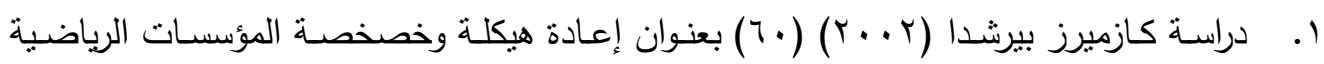

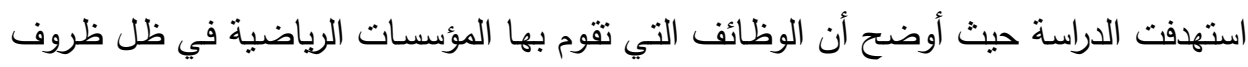
اقتصاد السوق الحر ، أصبحت أكثر صعوبة ونتجت هذة الصعوبة عن زيادة المنافسة في مجال

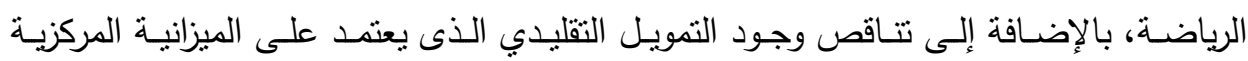

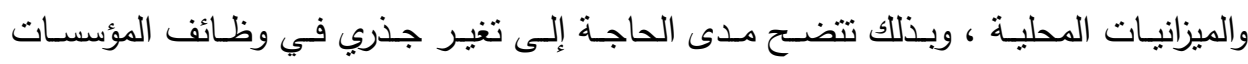

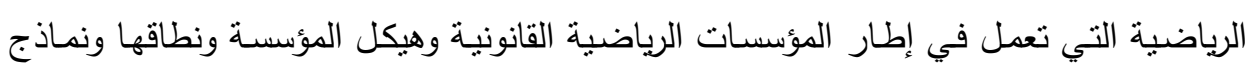

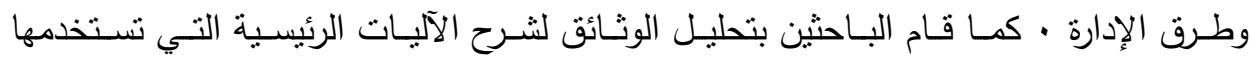

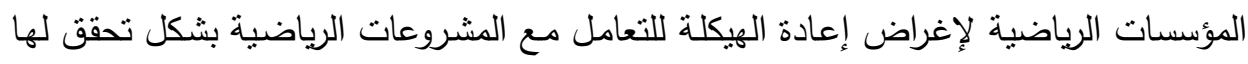

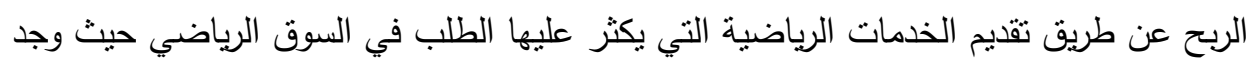

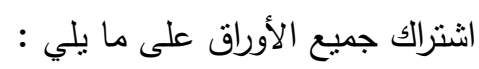

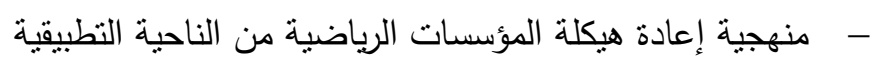
- - الإثكال القانونية لنقل الملكية فى المؤسسات الرياضية

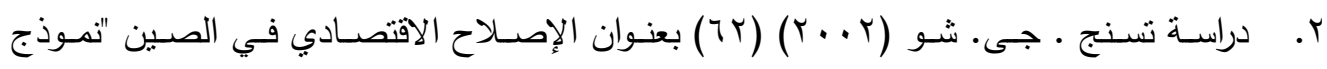

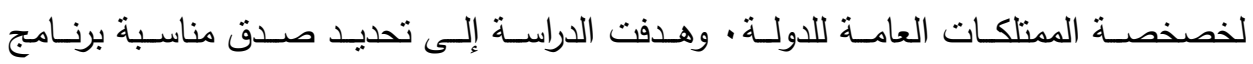
الخصخصة كبديل لامتلاك الدول للمشاريع · وتركز أهداف هذة الدراسة على اختبار ظاهرة الخصخصـة كظاهرة عالميـة، اختبار دور الحالـة الراهنـة للمؤسسـات الاقتصـادية ، تقييم البيئة 
الاقتصـادية ، السياسية ، الاجتماعيـة للصين لدراسـة إمكانيـة خصخصـة المؤسسـات ، تطوير

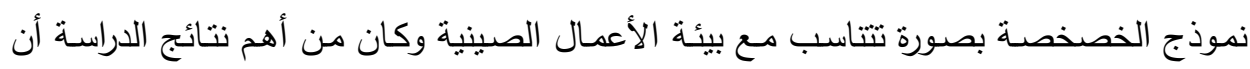
تركز الصين على الدور المتزايد للقطاع الخاص مع ضرورة انشأ عاصمة جديدة وضرورة تحديد

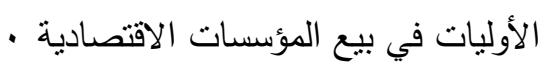

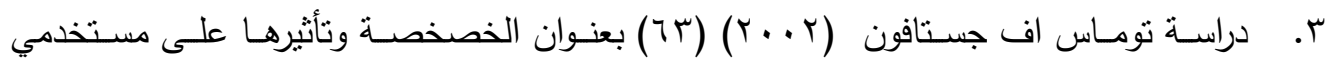
ملاعب الجولف ، وذلك بهدف التعرف على تأثثرات خصخصـة ملعب الجولف العامـة على بلى مستخدمي تلك الملاعب على مدار فصول السنة الأربعة واستخدمت الدراسة المنهج الوصفي

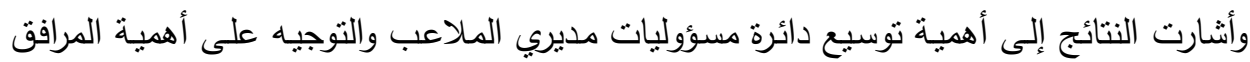

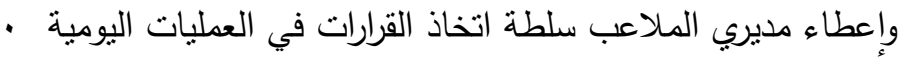

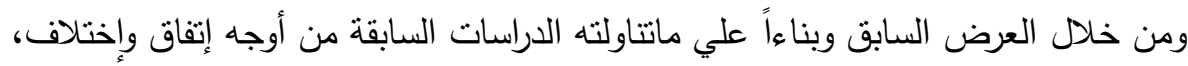
فقد إستفاد الباحثان من الدراسات السابقة في التالي:

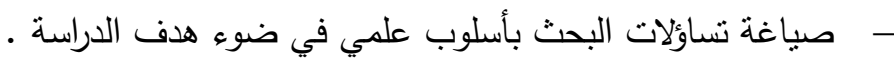

- - إختيار الإستنيان كأداة لجمع البيانات ، واستخدام الأسلوب والمعاملات الإحصائية المناسبة . - - الإستفادة من نتائج وتوصيات الدراسات السابقة في تقديم التوصيات والإقتراحات .

\section{منهج البحث}

قام الباحثينين باستخدام الدنهج الوصفي " الدراسات المسحية وذلك لمناسبته لطبيعة البحث

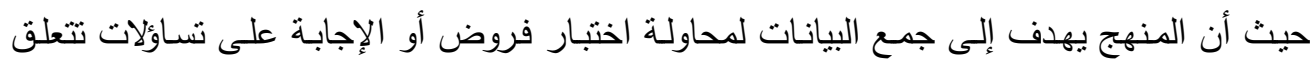

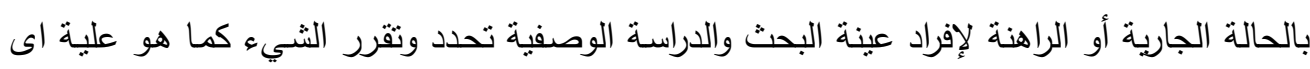
تصف ما هو كائن ولا يقف البحث الوصفي عند حد تجميع البيانات وتبوبيها وجدولتها ایى مجرد التوصل إلى الحقائق والحصول عليها ولكن يتضمن قدرا من التفسير لهذه البيانات .

\section{مجتمع وعينة البحث}

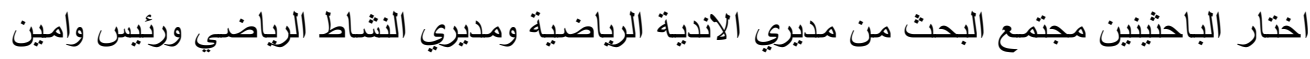

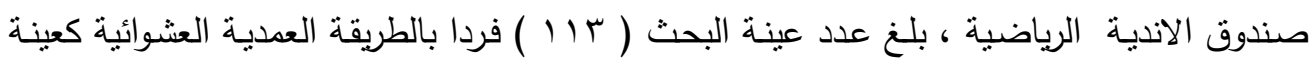

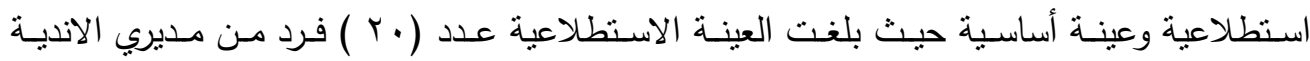

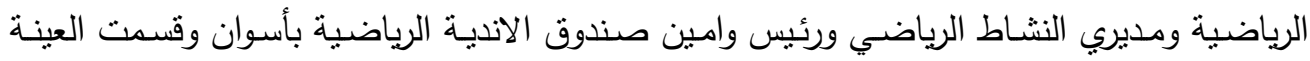

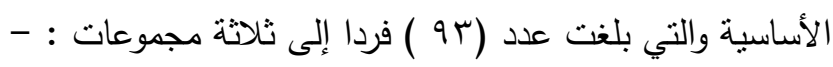


المجموعة الأولى : مديري الأندية الرياضية ومديرى النشاط الرياضى وعددهم ( بr ) فردا

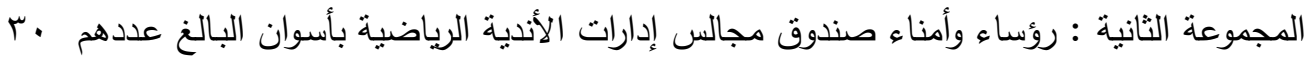

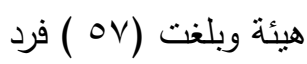

المجموعة الثالثة :خبراء الاستثمار وبرامج الخصخصة ودراسات الجدوى وعددهم (• ( ) ) أفراد ثانيا : مجتمع وعينة الوضع الراهن

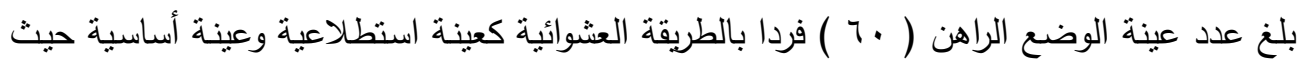

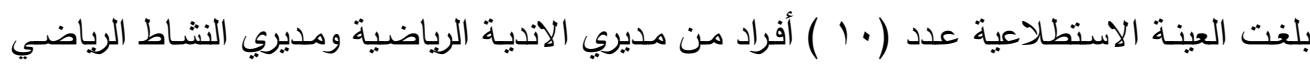
ورئيس وامين صندوق الاندية الرياضية بأسوان

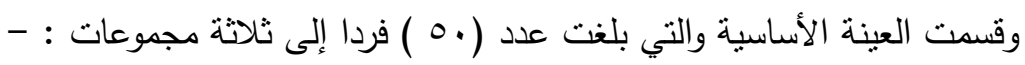

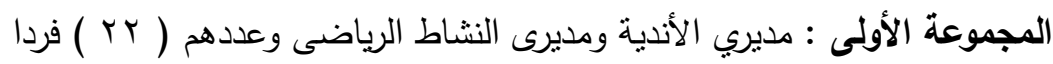

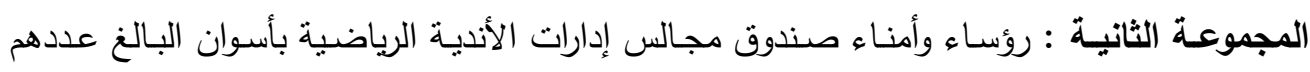
• ( Tr) المجموعة الثالثة :خبراء الاستثمار وبرامج الخصخصة ودراسات الجدوى وعددهم (0) أفراد جدول (r) مجتمع وعينة البحث

\begin{tabular}{|c|c|c|c|c|}
\hline \multicolumn{2}{|c|}{ مجتمع وعينة الدراسة } & \multicolumn{2}{|c|}{ مجتمع وعينة الوضع الراهن } & \multirow{2}{*}{ 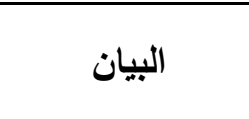 } \\
\hline النسبة المئوية & العينة & النسبة المئوية & العينة & \\
\hline \%१V.V. & r. & $\% 17.7 \mathrm{~V}$ & 1. & العينة الاستطلاعية \\
\hline$\%$ ॥.५.r. & $9 \pi$ & \% Аr.r & 0. & العينة الأساسية \\
\hline$\%$ & $11 \pi$ & $\% \quad 1 \ldots$ & 7. & المجموع \\
\hline
\end{tabular}




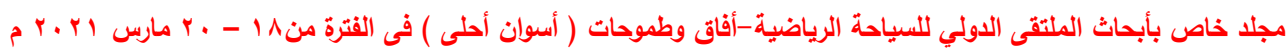

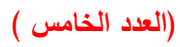

\section{جدول ( r ) \\ توصيف العينة}

\begin{tabular}{|c|c|c|c|c|c|c|c|c|}
\hline المئوية & الأساسية & المئوية & الاستطلاعية & المئوية & الأسياسية & النئبة & الاستطلاعية & \multirow{2}{*}{ البيان } \\
\hline & & & & & & الأساسية & الراهن & \\
\hline$\%$ \%Y.qT & ד Y & $\% 70$ & $1 \pi$ & $\% \varepsilon \varepsilon$ & Tr & $\%$ \%. & $r$ & الرالرياضدية \\
\hline $71 . \mathrm{rq}^{-}$ & v & $\%$ ० & v & $\% \leqslant 7$ & $r$ & $\%$. & v & رأرأد روأداء \\
\hline $1 . .10$ & 1. & - & - & $\% 1$. & 0 & - & - & والخبراء في \\
\hline$\% 1 \ldots$ & q & 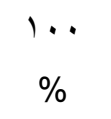 & $r$. & $\begin{array}{l}1 . \\
\%\end{array}$ & 0 . & $\begin{array}{l}1 \ldots \\
\%\end{array}$ & 1. & المجموع \\
\hline
\end{tabular}

استعان الباحثينين في استيفاء بيانات الدراسة بالاستيات كأداة لجمع البيانات .

$$
\begin{aligned}
& \text { أولا : استبيان الوضع الراهن : }
\end{aligned}
$$

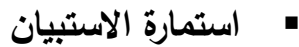

قام الباحثينين بتصميم استمارة استنيان عن الوضع الراهن لإدارة الأنديـة الرياضية بهدف

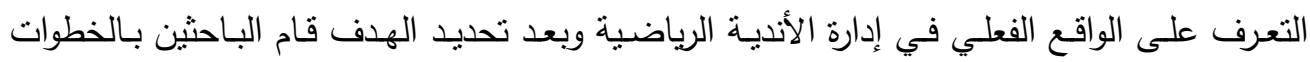




\section{1- تحديد المحاور الرئيسية للاستبيان :}

قام الباحثينين بـالاطلاع على المراجع العلميـة وكذا الدوريات والقرارات الصـادرة من وزارة

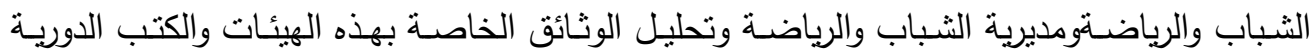
المعدلة له وذللك للتعرف على أسلوب إدارة الأندية الرياضية بالإضافة إلى اللوائح المالية الخاصة بها

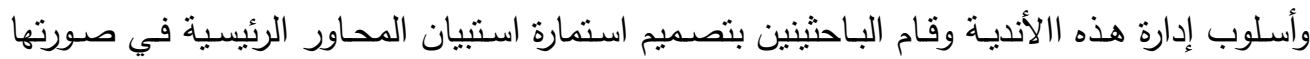

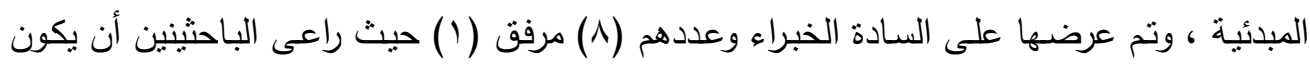

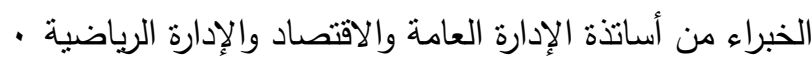

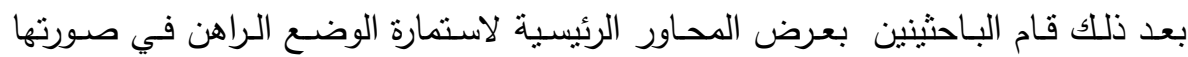

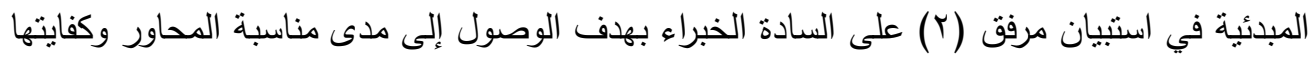

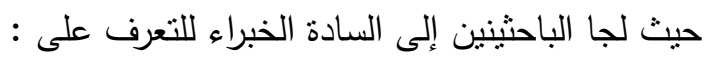

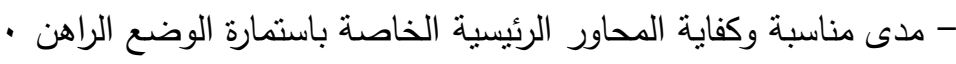

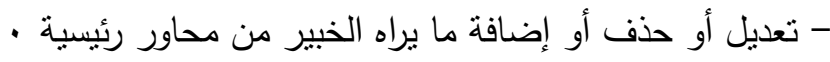
وبعد عرض الاستمارة على السـادة الخبراء ، قام الباحتينين بحساب النسبة المئويـة لأراء

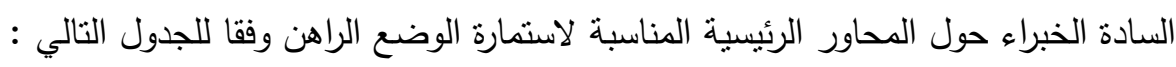
جدول (rr)

الأهمية النسبية لاتفاق الخبراء حول محاور استمارة استبيان

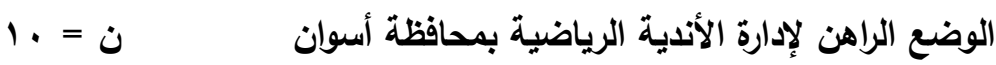

\begin{tabular}{|c|c|c|c|}
\hline الأهمية النسبية & اتفاق أراء الخبراء & المحاور & م \\
\hline$\% 1 \ldots$ & $\wedge$ & الأهداف & 1 \\
\hline$\% \vee 0$ & 7 & التخطيط & r \\
\hline$\% \vee 0$ & 7 & التتظيم & r \\
\hline$\% \wedge \vee . \diamond$ & v & الإمكانيات & $\varepsilon$ \\
\hline$\% 1 \ldots$ & $\wedge$ & القيادة & 0 \\
\hline$\% \vee 0$ & 7 & الرقابة & 7 \\
\hline
\end{tabular}

يتضـح من الجدول (rr) أن النسبة المئويـة لأراء السـادة الخبراء حـول الدحاور الرئيسية

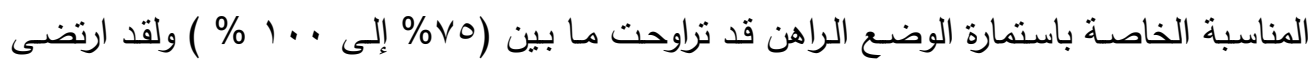

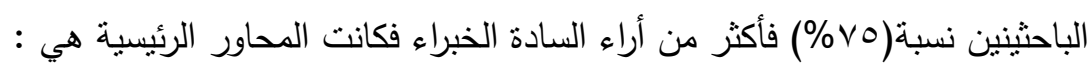


المحور الأول : الأهداف ، المحور الثاني : التخطيط ، المحور الثالث : التتظيم

الدحور الرابع : الإمكانيات ، الدحور الخامس : القيادة ، المحور السادس : الرقابة

r- ب إعداد عبارات الاستبيان :

في ضوء نتائج اطلاع الباحثنين على قانون الرياضة والمراجع والدوريات والقرارات

الصادرة من وزارة الثباب والرياضة ومديرية الثباب والرياضة وتحليل الوثائق الخاصة والكتب الدورية المعدلة له وذلك للتعرف على اللوائح المالية الخاصة بها وأسلوب إدارة هذه الاندية ونتائج أراء الخبراء

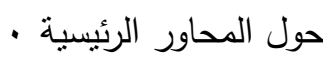

ثم قام الباحثينين بصياغة مجموعة من العبارات التي يمكن أن تتدرج تحت كل

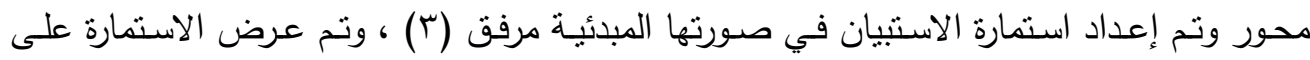

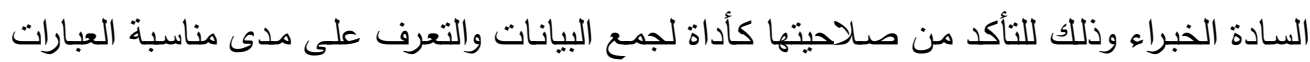

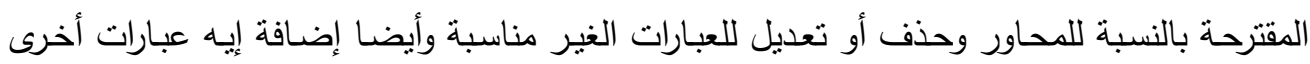

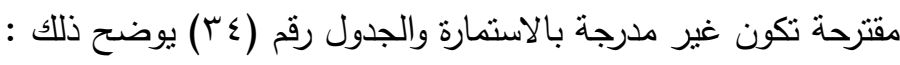

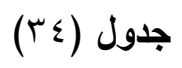

النسبة المئوية لاتفاق السادة الخبراء حول عبارات محاور استبيان الوضع الراهن

\begin{tabular}{|c|c|c|c|c|c|c|}
\hline الرقابة & القيادة & الإمكانيات & التنظيم & التخطيط & الأهداف & العبارها \\
\hline$v^{\prime}$. & 9. & 80 & $V$. & 70 & $V$. & 1 \\
\hline $1 \ldots$ & $1 \ldots$ & $1 \ldots$ & 90 & $1 \ldots$ & 9. & $r$ \\
\hline 70 & 90 & $1 \ldots$ & $1 \ldots$ & 9. & $1 \ldots$ & $r$ \\
\hline $1 \ldots$ & $1 \ldots$ & $\Lambda$. & 90 & $1 \ldots$ & $1 \ldots$ & $\varepsilon$ \\
\hline $1 \ldots$ & $V$. & 0. & 90 & 60 & 0. & 0 \\
\hline$\Lambda$. & $1 \ldots$ & 80 & $1 \ldots$ & $V$. & $1 \ldots$ & 7 \\
\hline 9. & $1 \ldots$ & 7. & $1 \ldots$ & $1 \ldots$ & $\Lambda$. & V \\
\hline 9. & $V$. & $\Lambda$. & $1 \ldots$ & $\wedge$. & A. & $\Lambda$ \\
\hline $1 \ldots$ & $1 \ldots$ & 9. & $V$. & $1 \ldots$ & 90 & 9 \\
\hline$\wedge$. & $v$. & 90 & $1 \cdots$ & $V$. & A. & 1. \\
\hline$V$. & $V$. & $1 \ldots$ & $V$. & $1 \ldots$ & 9. & 11 \\
\hline$\wedge$. & $\Lambda$. & 1. & $1 \ldots$ & $V$. & 90 & Ir \\
\hline$v$. & $\Lambda$. & 90 & 9. & $\Lambda$. & $V$. & 14 \\
\hline
\end{tabular}




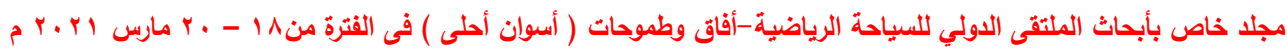

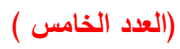

\begin{tabular}{|c|c|c|c|c|c|c|}
\hline$V$. & $1 \ldots$ & 60 & 50 & $1 \ldots$ & $V$. & $1 \varepsilon$ \\
\hline$\Lambda$. & $1 \ldots$ & 0. & 90 & $1 \ldots$ & $\Lambda$ & 10 \\
\hline 0. & 90 & $1 \ldots$ & $1 \ldots$ & $\Lambda$. & $V$. & 17 \\
\hline \multirow[t]{6}{*}{7.} & 7. & 60 & $V \cdot$ & & & IV \\
\hline & & 9. & $\Lambda$ & & & 11 \\
\hline & & $\mathrm{V}$. & $V \cdot$ & & & 19 \\
\hline & & $1 \ldots$ & 9. & & & $r$. \\
\hline & & 90 & $1 \ldots$ & & & YI \\
\hline & & $V$. & $V$. & & & Yr \\
\hline
\end{tabular}

يتضـح من الجدول (؟ب) أن النسبة المئوبـة لأراء الخبراء حول مناسبة العبارات المقترحة لمحاور الاستبيان تراوحت ما بين ( •0\% إلى . . (\%) وفى ضوء ذلك ارتضى الباحثين نسبة موافقة

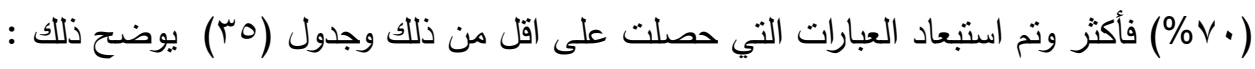

$$
\text { جدول (ro) }
$$

عدد عبارات الاستبيان قبل ويعد العرض على الخبراء

\begin{tabular}{|c|c|c|c|c|}
\hline العرض على الخبراء & عدد العبارات بعد & عدد العبارات قبل العرض على الخبراء & المحاور & s \\
\hline 10 & & 17 & الأهداف & 1 \\
\hline 10 & & 17 & التخطبط & $r$ \\
\hline YI & & TY & التتظيم & $\Gamma$ \\
\hline iv & & rr & الإمكانيات & $\varepsilon$ \\
\hline 17 & & 18 & القيادة & 0 \\
\hline 10 & & IV & الرقابة & 7 \\
\hline 11 & & 11. & \multicolumn{2}{|c|}{ الاجمالى } \\
\hline
\end{tabular}

وقام الباحثُن باستطلاع أراء الخبراء حول مدى كفاية عبارات كل محور من محاور

الاسنتيان

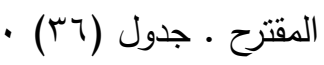


جدول (rT)

النسبة المئوية لأراء الخبراء في مدى كفاية عبارات محاور الاستبيان

\begin{tabular}{|c|c|c|c|}
\hline غير كفاية & كفاية & عبارات المحاور & م \\
\hline- & $\%$ & الأهداف & 1 \\
\hline- & $\% 1 \ldots$ & التخطيط & $r$ \\
\hline- & $\% 1 \ldots$ & التنظيم & $r$ \\
\hline- & $\% 1 \ldots$ & الإمكانيات & $\varepsilon$ \\
\hline- & $\% 1 \ldots$ & القيادة & 0 \\
\hline- & $\% 1 \ldots$ & الرقابة & 7 \\
\hline
\end{tabular}

يتضـح مـن الجـول ( ب ) أن النسـبة المئويـة لأراء الخبـراء حـول مـدى كفايـة عبـارات

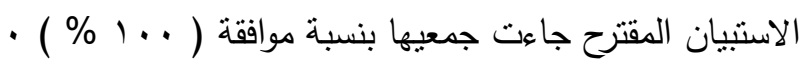

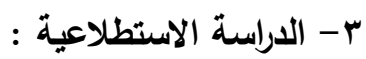

قام الباحثينين بإجراء دراسـة استطلاعية على عينـة قوامها ( • ( ) إفراد مـ خـارج العينـة

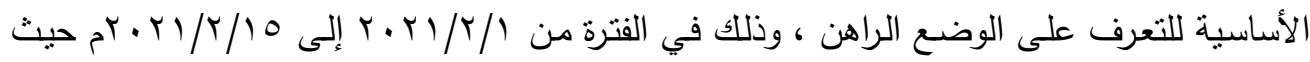
استهدفت الدراسة الاسنطلاعية التعرف على :

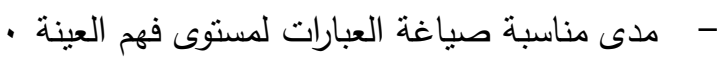

- التأكد من عدم وجود اى عبارات يصعب فهمها -

-

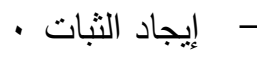

ولقد أظهرت نتائج الدراسة الاستطلاعية أن الاستبيان جاء مناسبا من حيث الصياغة واللغة

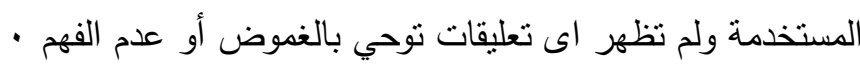

؛ - المعاملات العلمية لاستمارة الاستبيان :

1- صدق الاستبيان :

استخدم الباحثنين صدق الاتساق الداخلي لحساب معامل الصدق للاستبيان وذلك بهدف

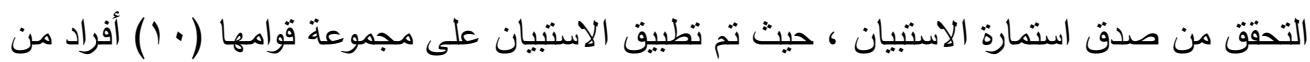

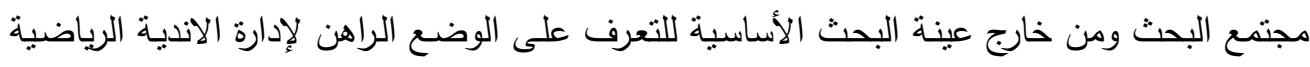

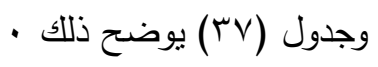




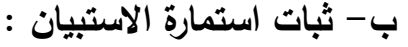

استخدم الباحثينين طريق الاختبار وإعادة تطبيقه لحساب معامل الثبات لاستمارة الاستبيان

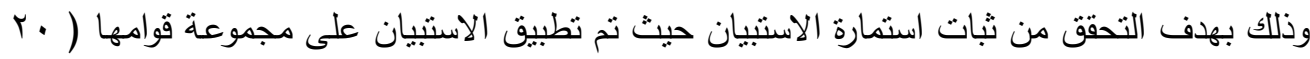

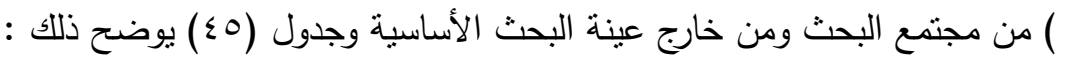

\section{جدول(0)}

معاملات الارتباط بين التطبيق الأول والثاني

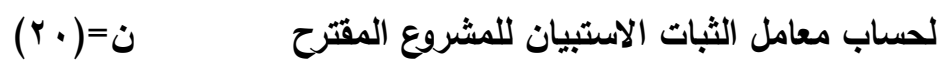

\begin{tabular}{|c|c|c|c|c|c|}
\hline \multirow{2}{*}{ الارتباط } & \multicolumn{2}{|c|}{ التطبيق الثاني } & \multicolumn{2}{|c|}{ التطبيق الأول } & \multirow{2}{*}{ 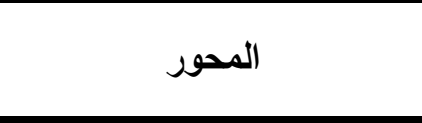 } \\
\hline & $\varepsilon$ & س س & $\varepsilon$ & س & \\
\hline. .10 &. $.7 \mathrm{~V}$ & T.10 &..$V Y$ & r.Vq & أساليب الخصخصة الجزئية \\
\hline..$\wedge V$ &..$\leqslant \Gamma$ & r.7 &. $.7 r$ & T.TE & الجوانب القانونية والإدارية \\
\hline..$V V$ &. .74 & T.TV &. $.7 \mathrm{~V}$ & Y.AI & أساليب التسويق \\
\hline .94 &. .00 & Y.VY &..$\leqslant \wedge$ & Y.07 & التخطيط لإدارة الاندية الرياضية \\
\hline. .90 & T & T.Yo & $.0 \leqslant$ & r.IV & أساليب المنابعة والتقويم \\
\hline $.9 \pi$ &.$\cdot v 1$ & T.VY &. .11 & Y.77 & الفائدة الاقتصادية والاجتماعية \\
\hline
\end{tabular}

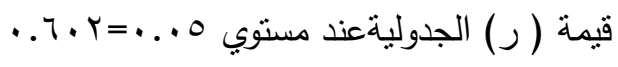

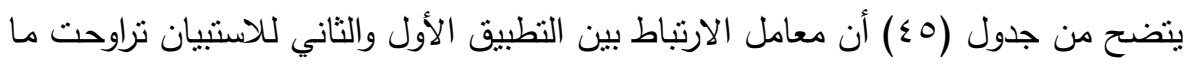

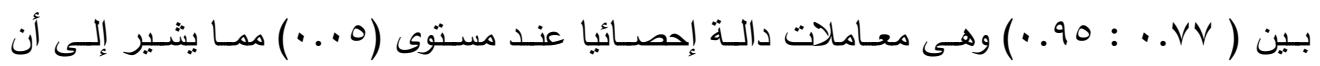

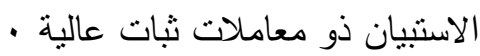
ه- تطبيق استبيان ( الارسة الأساسية ) :

قـام البـاحثينين بنطبيق الاستيبان لاستمارة إدارة الانديـة الرياضية بنظسام الخصخصــة

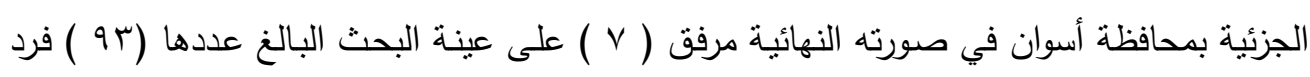

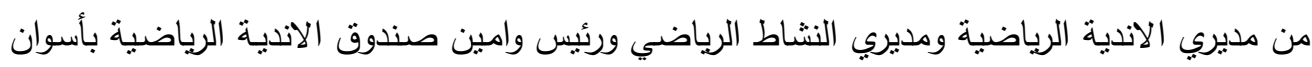

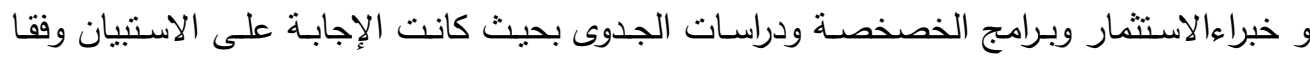
لميزان تقدير ثلاثي ( نعم - إلى حد ما - لا ) ) بناء على رأى الخبراء وتم تجميع البيانات وجدولتهات الإنها

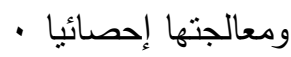

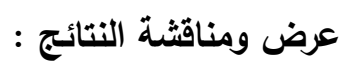
عرض ومناقثة نتائج الوضع الراهن لإدارة الاندية الرياضية بمحافظة أسوان 


\section{جدول (צ ؛ )}

الارجة المقدرة والنسبة المئوية لأراء عينة البحث في

المحور الأول : الأهداف الاف ل

\begin{tabular}{|c|c|c|c|c|c|c|}
\hline 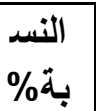 & المقرة - المة & لا & إلى حلا & نعم & 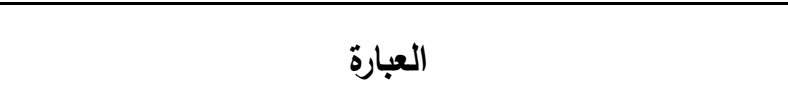 & م \\
\hline $\begin{array}{c}48 . \\
8\end{array}$ & 122 & rV & 1. & r & توجد أهداف محددة لإدارة الاندية الرياضية & 1 \\
\hline $\begin{array}{c}67 . \\
2\end{array}$ & 168 & 10 & 11 & $r \varepsilon$ & تتفق أهداف إدارة الاندية الرياضية بمحافظة أسوان مع القعاف & 2 \\
\hline $\begin{array}{c}46 . \\
4\end{array}$ & 116 & rq & 9 & ir & أهداف إدارة الاندية الرياضية واضحة ومعروفة للعاملين & 3 \\
\hline $\begin{array}{c}39 . \\
2\end{array}$ & 98 & $r \varepsilon$ & $\wedge$ & $\wedge$ & توجد سياسات مكتوبة ومحددة في ضوء الأهداف & 4 \\
\hline $\begin{array}{c}35 . \\
2\end{array}$ & 88 & ro & 11 & $\varepsilon$ & تتناسب أهداف إدارة الاندية مع الإمكانيات المادية المتاحة & 5 \\
\hline $\begin{array}{c}50 . \\
4\end{array}$ & 126 & ry & 1. & $1 \varepsilon$ & تتتاسب أهداف إدارة الاندية مع الإمكانيات البشرية المتاحة & 6 \\
\hline $\begin{array}{c}36 . \\
8\end{array}$ & 92 & rq & 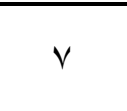 & v & أهداف إدارة الاندية الرياضية واقعية وقابلة للتحقيق & 7 \\
\hline 40 & 100 & ro & 0 & 1. & يتم تعديل الأهداف الموضوعة من قبل الإدارة فى ضوء ما & 8 \\
\hline $\begin{array}{c}78 . \\
4\end{array}$ & 196 & 1. & 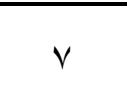 & r & توجد عقبات تحول دون التخطيط للأهداف الموضوعة & 9 \\
\hline $\begin{array}{c}48 . \\
8\end{array}$ & 122 & $r \wedge$ & $\wedge$ & $1 \varepsilon$ & أهداف إدارة الاندية الرياضية بأسوان تتفق مع متغيرات & 10 \\
\hline 44 & 110 & rt & 7 & ir & تتوافر خطة واضحة لاحتياجات العمل لتحقيق أهداف أدارة & 11 \\
\hline $\begin{array}{c}69 . \\
6\end{array}$ & 174 & $\varepsilon$ & r. & 17 & أهداف إدارة الاندية الرياضية يمكن قياس مدى تحقيقها & 12 \\
\hline $\begin{array}{c}36 . \\
8\end{array}$ & 92 & $r v$ & 0 & $\wedge$ & توجد معايير توضح مدى تحقيق الأهداف الخاصة بإدارة & 13 \\
\hline 52 & 130 & 17 & ru & 7 & يقتتع مديري الاندية الرياضية والعاملين بأهداف إدارة هذة & 14 \\
\hline
\end{tabular}




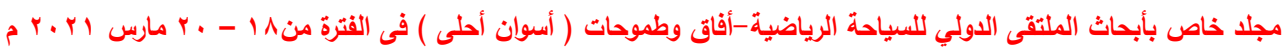

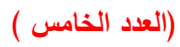

\begin{tabular}{|c|c|c|c|c|c|c|}
\hline 52 & 130 & $1 \varepsilon$ & Tr & $\varepsilon$ & يتم تحقيق أهداف إدارة الاندية الرياضية من خلال الخطط & 7 \\
\hline $\begin{array}{l}\leqslant q . \\
v 1\end{array}$ & 1864 & & & & & \\
\hline
\end{tabular}

$$
\text { يتضح من جدول ( } 1 \text { ؛ ) ما يلي : }
$$

- أن النسـبة المئويـة لأراء عينـة التعـرف على الوضـع الـراهن في أسـلوب إدارة الانديـة الرياضية في محور (الأهداف) ، قد تراوحت ما بين (35.2\% : الارة

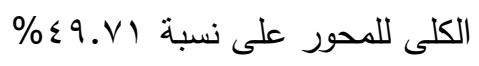

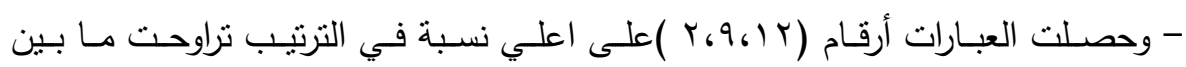

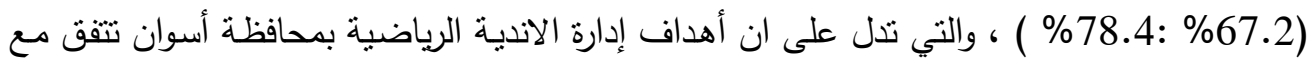

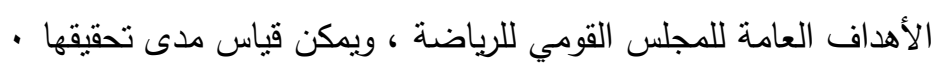

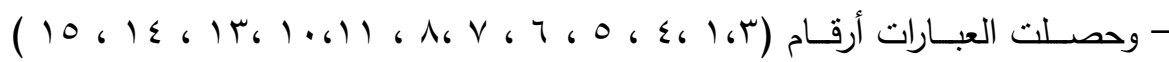

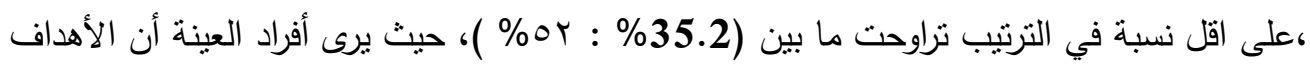

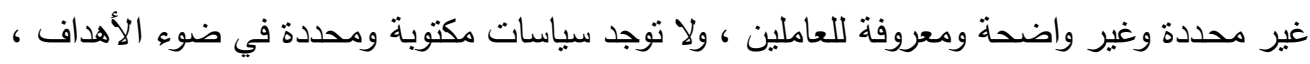

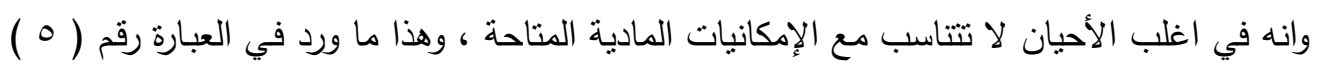

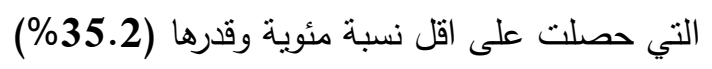

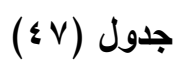

\begin{tabular}{|c|c|c|c|c|c|c|}
\hline النسبة\%\% & الدرجة المقدرة & y & إلى حـا & نعم & العبارة & p \\
\hline 47.2 & 118 & rA & 1. & Ir & توضع خطط إدارة الاندية الرياضية قبل & 1 \\
\hline 49.6 & 124 & ru & 17 & $\wedge$ & تتتاسب الخطط الموضوعة مع أهداف & 2 \\
\hline 52.8 & 132 & r & זr & $\varepsilon$ & يتم تتفيذ الخطط الموضوعة من خلال & 3 \\
\hline 67.2 & 168 & 0 & $r_{1}$ & $1 \varepsilon$ & يراعى مواعيد توقف الأنشطة الرياضية & 4 \\
\hline
\end{tabular}

\section{الارجة المقدرة والنسبة المئوية لأراء عينة البحث في}

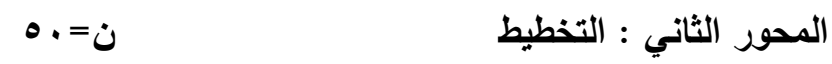




\begin{tabular}{|c|c|c|c|c|c|c|}
\hline 36.8 & 92 & ru & V & V & نوجد خطط لإدارة الاندية الرياضية & 5 \\
\hline 72.8 & 182 & 11 & IT & TV & الخطط الموضوعة يمكن تتفيذها فى الإمكانيات المتاحة & 6 \\
\hline 44 & 110 & $r$. & 1. & 1. & وبين خطط تمبيق بين خطط إدارة الاندية & 7 \\
\hline 61.6 & 154 & 9 & $r$. & 11 & يتم التتسيق بين خطط إدارة الاندية إدارة الاندية المركزية & 8 \\
\hline 45.6 & 114 & rV & $1 \varepsilon$ & 9 & تنساعد خطط وبرامج إدارة الاندية & 9 \\
\hline 40.8 & 102 & rT & 1. & $\wedge$ & تحقيق رغبات غطط إلدارة الاندية الرياضية الرياتية & 10 \\
\hline 32.8 & 82 & $\varepsilon$ & $\varepsilon$ & 7 & يوجد تخطيط لتوفير الأدوات الرياضية & 11 \\
\hline 38.4 & 96 & re & $r$ & 1. & يوجد تخطيط لزيادة عدد هذه الاندية & 12 \\
\hline 43.2 & 108 & rA & 10 & V & يوجد تخطيط لرفع كافة هذه الاندية & 13 \\
\hline 39.2 & 98 & $r$ & $1 \varepsilon$ & 0 & يوجد تخطيط لتطوير مستوى الخدمة & 14 \\
\hline 53.6 & 134 & 10 & YA & $v$ & توجد خطط تدريبية كافية لتدريب & 10 \\
\hline$\Sigma \Lambda . r \vee$ & 1814 & & & & & \\
\hline
\end{tabular}

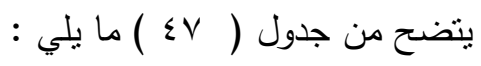

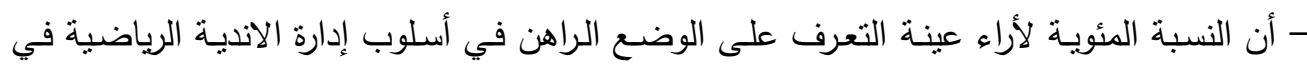

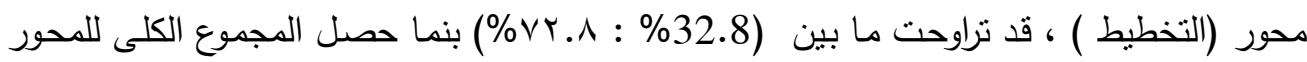

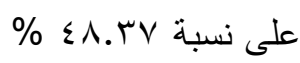

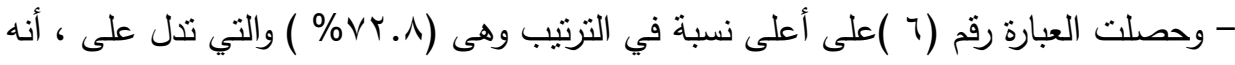
يمكن تتفيذ الخطط الموضوعة في حدود الإمكانيات المتاحة .

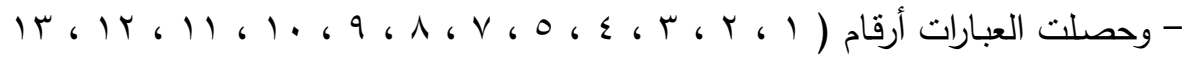

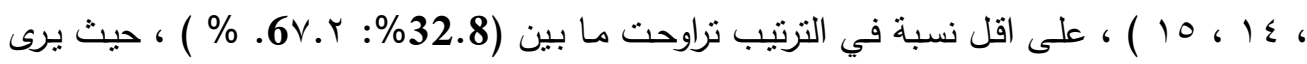
أفراد العينة انه لا توضع خطط إدارة الانديـة الرياضية قبل التتفيذ بوقت كافي ، وانه لا يتم تتفيذ 
الخطط الموضـوعة من خـلال خطوات مرحليـة ، بالإضـافة إلى انه لا توجد خطط لإدارة الانديـة الرياضية طويلة المدى من r إلى 0 سنوات ، ولا يوجد تتسيق بين خطط إدارة الاندية وبين خطط

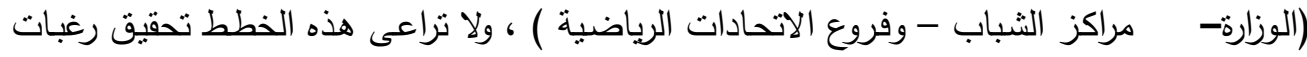

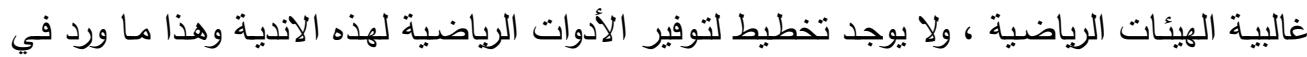
العبارة رقم ( 11 ) التي حصلت على اقل نسبة مئوية وقدرها (32.8\% ) ، ولا يوجد تخطيط لزيادة

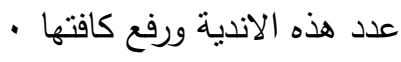

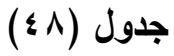

الارجة المقدرة والنسبة المئوية لأراء عينة البحث في

المحور الثالث : التنظيم

$$
0 .=\dot{0}
$$

\begin{tabular}{|c|c|c|c|c|c|c|}
\hline النسبة\%\% & المقرجة & $\gamma$ & 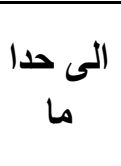 & نعم & 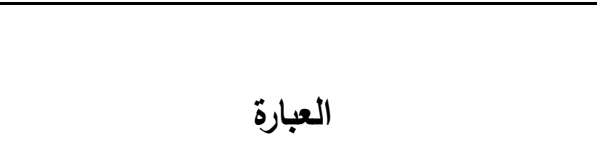 & p \\
\hline 75.2 & 188 & 1. & 11 & rq & يوجد هيكل تتظيمي لإدارة الاندية الرياضية & 1 \\
\hline 43.2 & 108 & r. & 11 & 9 & توجد عدالة في توزيع العمل على العاملين & 2 \\
\hline 87.2 & 218 & r & 1. & rv & الهيكل التتظيمي الموجود يحتاج الى تعديل & 3 \\
\hline 52.8 & 132 & Tr & سץ & $\varepsilon$ & يتطابق الهيكل التظيمي مع التقسيم الفعلي & 4 \\
\hline 42.4 & 106 & rT & $\wedge$ & 1. & عدم وضوح الهيكل التظظيمي بادارة الاندية & 5 \\
\hline 40.8 & 102 & rr & $\Lambda$ & 9 & 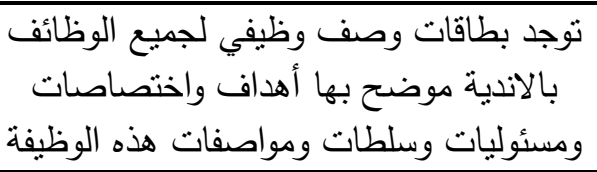 & 6 \\
\hline 72.8 & 182 & 11 & ir & rV & يوجد دليل مكتوب يحدد اختصاصات إدارة & 7 \\
\hline 56 & 140 & 10 & ro & 1. & ينم مراجعة التنظيم وتتظيم العمل بشكل & 8 \\
\hline 59.2 & 148 & Tr & ro & Ir & التوصيف الوظيفي داخل إدارة الاندية واضح & 9 \\
\hline
\end{tabular}




\begin{tabular}{|c|c|c|c|c|c|c|}
\hline 47.2 & 118 & $r \wedge$ & 1. & ir & يتسم التتظيم الحالي بالمرونة الكافية & 10 \\
\hline 44.8 & 112 & rq & 11 & 1. & ينم تطوير الهيكل التنظيمي لإدارة الاندية & 11 \\
\hline 80 & 200 & $\wedge$ & 9 & 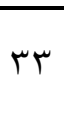 & هناك إجراءات محددة لتنفيذ الأعمال الإدارية & 12 \\
\hline 80.8 & 202 & $\wedge$ & $\wedge$ & $r \varepsilon$ & عدم تعاون العاملين في إدارة الاندية يؤدى & 13 \\
\hline 44 & 110 & r. & 1. & 1. & يوجد بالهيكل التتظيمي جميع الوظائف التي & 14 \\
\hline 70.4 & 176 & ir & ז & ro & توجد لائحة تتظيمية تحدد العلاقة بين مدير & 10 \\
\hline 71.2 & 178 & 11 & $1 \leq$ & ro & توجد لائحة تتظيمية تحدد العمل بهذه الاندية & 17 \\
\hline 60 & 150 & 1. & $r$. & 1. & يتم الاستعانة بعمالة فنية من خارج الادارة & iv \\
\hline 42.4 & 106 & r & 7 & 11 & يتم تطبيق أساليب الإدارة الحديثة في إدارة & 11 \\
\hline 32 & 80 & ro & 10 & . & الرياضية علي المستوي الداخلي والخارة لتسويق الاندية & 19 \\
\hline 62.4 & 156 & 0 & rv & $\wedge$ & يوجد بإدارة الاندية الرياضية عمالة فنية & \\
\hline 27.2 & 68 & $\varepsilon 1$ & 9 & . & توجد بإدارة الاندية إدارة متخصصة في & $r_{1}$ \\
\hline 56.76 & $\begin{array}{c}298 \\
0\end{array}$ & & & & & \\
\hline
\end{tabular}

$$
\text { يتضح من جدول ( ؛ ؛ ) ما يلي : }
$$

- أن النسبة المئويـة لأراء عينـة التعـرف على الوضـع الـراهن في أسـلوب إدارة الانديـة

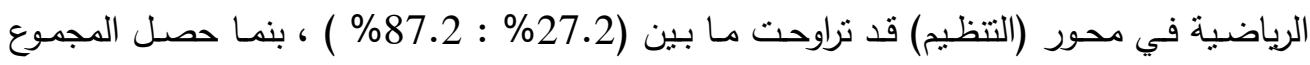

$$
\text { الكلى للمحور على نسبة 56.76\% }
$$

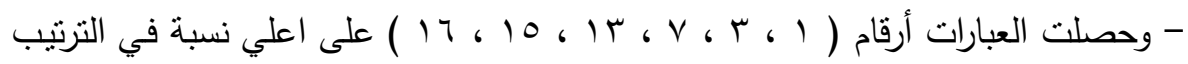

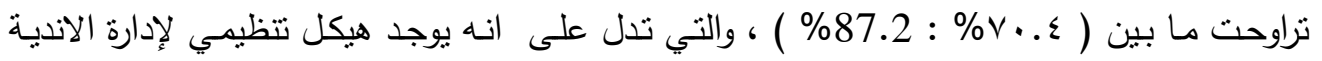

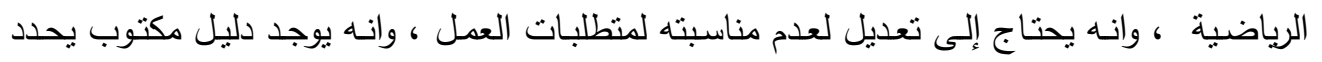


اختصاصات إدارة الاندية ، وان هناك بالفعل إجراءات محددة لتتفيذ الأعمال الإدارية بإدارة الاندية ،

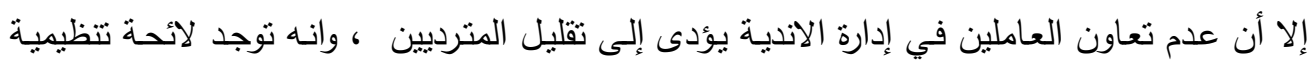

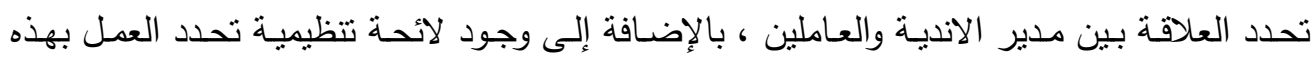
· الاندية

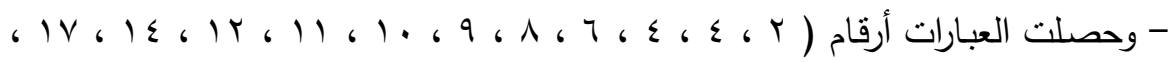

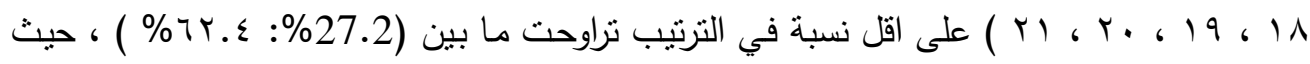

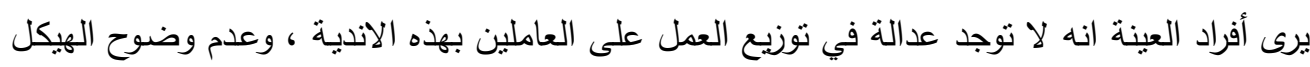

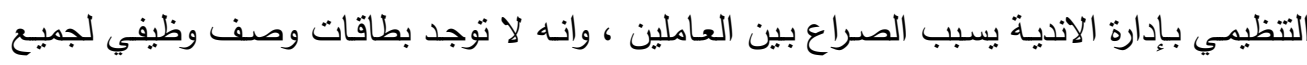

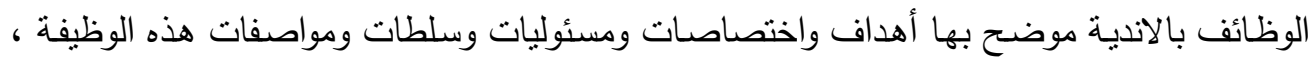
وان التنظيم الحالي لا يتسم بالمرونة الكافية ، وانه لا يتم التطوير في الهيكل التنظيمي لإدارة الاندية

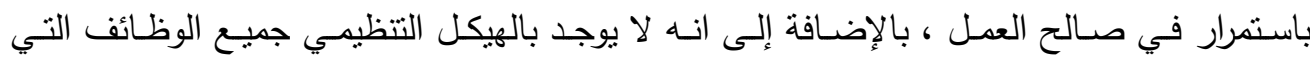

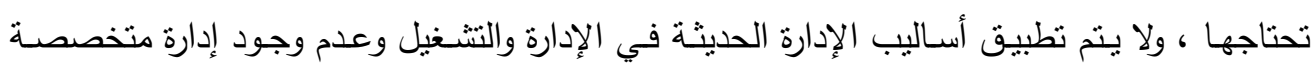

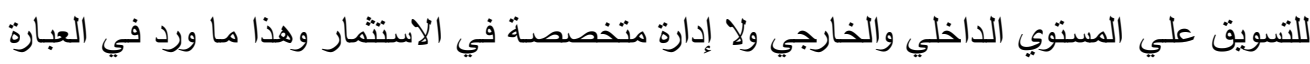
رقم ( r ) التي حصلت على اقل نسبة مئوية وقدرها (27.2\% ) • 


\section{جدول (9 ؛ )}

الارجة المقدرة والنسبة المئوية لأراء عينة البحث في

المحور الرابع :الإمكانيات

$$
0 .=\dot{0}
$$

\begin{tabular}{|c|c|c|c|c|c|c|}
\hline النسبةة & المقرجة & $\gamma$ & 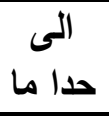 & نعم & العبارة & م \\
\hline 44.8 & 112 & $r q$ & 11 & 1. & 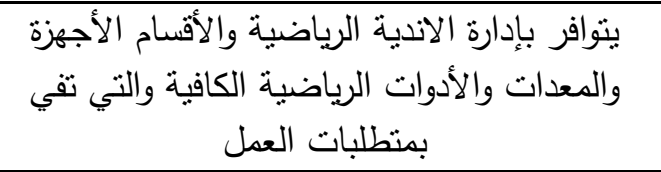 & 1 \\
\hline 35.2 & 88 & rr & $1 V$ & 1 & يتوافر بادارة الاندية الرياضية والأقسام الأجهزة & 2 \\
\hline 46.4 & 116 & $r q$ & 9 & 14 & الملاعب والصرالات عدد كافي بإدارة الاندية الرياضية من العاتلات وحمامات & 3 \\
\hline 52.8 & 132 & ro & 9 & 17 & تتتاسب الأدوات الرياضية الموجودة مع كم المترديين على الاندية الرياضية & 4 \\
\hline 76.8 & 192 & $\wedge$ & & rq & يوجد نقص فى عمالة الخدمات لمعاونة العاملين & 5 \\
\hline 57.6 & 144 & r & $r V$ & 1. & تهنم القيادة العليا بتوفير الإمكانيات اللازمة & 6 \\
\hline 40 & 100 & rr & 11 & V & 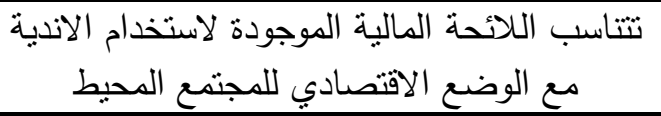 & 7 \\
\hline 37.6 & 94 & rv & $\varepsilon$ & 9 & 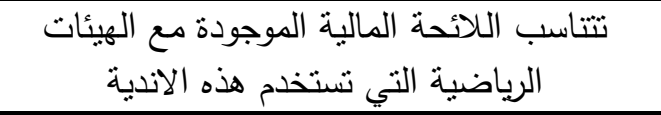 & 8 \\
\hline 39.2 & 98 & rs & $\Lambda$ & $\Lambda$ & 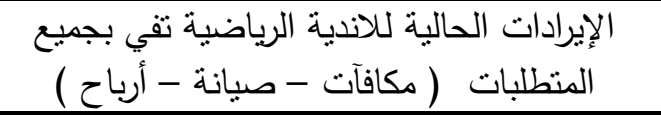 & 9 \\
\hline 42.4 & 106 & سT & 7 & 11 & الرياضية ت تفي بالغرض الأليب المالية المتبعة حالياً للاندية وضعت من أجلها & 10 \\
\hline 62.4 & 156 & 11 & ro & $1 \leq$ & بنود وفقرات اللائحة المالية المتبعة حالياً قابلة & 11 \\
\hline 52 & 130 & rV & 7 & IV & توجد لائحة تتظيمية تحدد نوزيع الميزانية على الاندية & 12 \\
\hline 92 & 230 & • & 1. & $\varepsilon$ & يتم الحاجة الى الدعم الحكومي لمواجهة منطلبات & 13 \\
\hline
\end{tabular}




\begin{tabular}{|c|c|c|c|c|c|c|}
\hline & & & & & 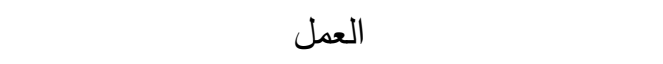 & \\
\hline 32 & 80 & ro & 10 & . & توزع أرباح في نهاية العام المالي على العاملين & 14 \\
\hline 69.6 & 174 & r & it & ro & توجد حوافز شهريا للعاملين بالاندية تعتمد على ما & 10 \\
\hline 60.8 & 152 & $\wedge$ & r & 9 & عدد العاملين بإدارة الاندية كافي ومناسب لتقديم & 17 \\
\hline 36.8 & 92 & ro & 9 & 7 & يتم صقل العاملين بالإدارات الفنية بالدورات & IV \\
\hline 51.67 & 2196 & & & & & \\
\hline
\end{tabular}

بتضح من جدول(9 ؛ ) ما يلي :

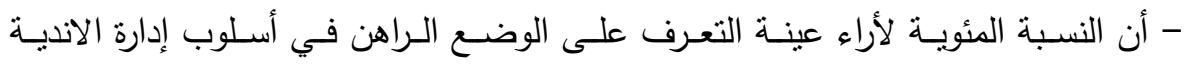

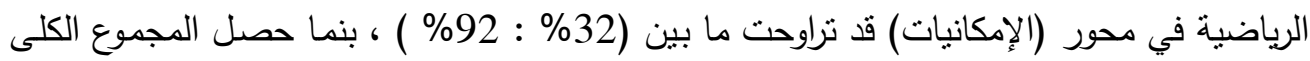

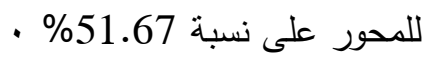

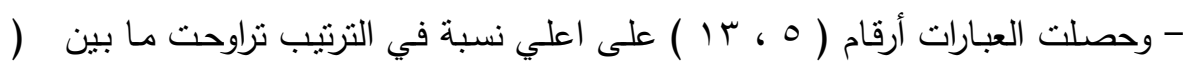
• . .

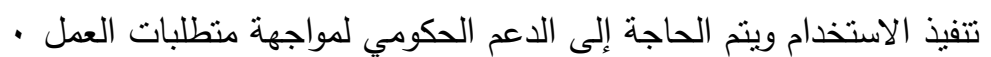

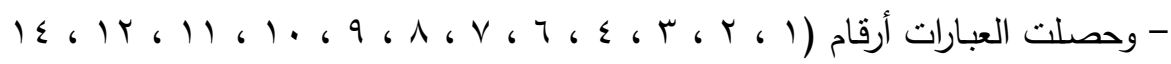

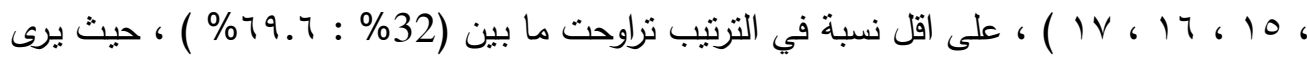
أفراد العينة انه لا يتوافر بإدارة الاندية الرياضية والأقسام الأجهزة والمعدات والأدوات الرياضية الكافية

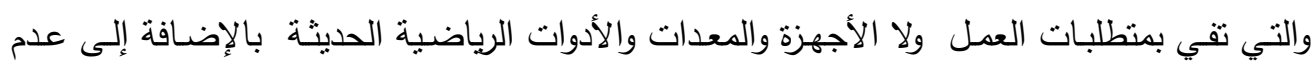

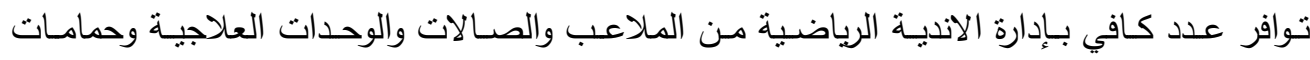
السباحة ، وعدم تتاسب الأدوات الرياضية الموجودة مع كم المترديين على الاندية الرياضية ، فضلا

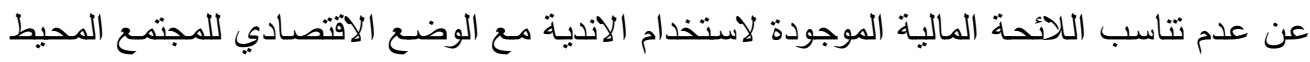

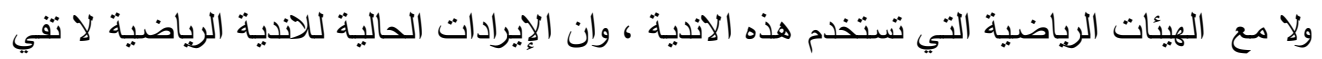

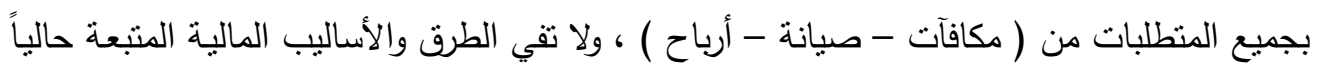

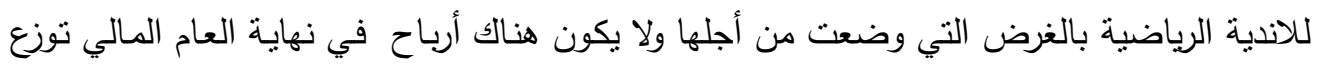

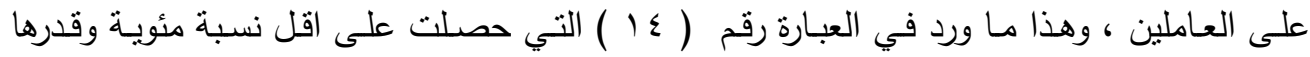

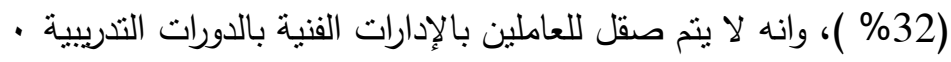




\section{جدول (•)}

الارجة المقدرة والنسبة المئوية لأراء عينة البحث في

المحور الخامس: القيادة

$$
0 .=\dot{0}
$$

\begin{tabular}{|c|c|c|c|c|c|c|}
\hline النسبة\% & المقرة - الارجة & $\gamma$ & الى حدا ما & نعم & العبارة & \\
\hline 50.4 & 126 & 11 & Y & 1 & يتوافر لقيادات إدارة الاندية الرياضية & 1 \\
\hline 59.2 & 148 & 11 & rq & 1. & تتصف قالمهارات الإنسانية في التعل بالندية الرياضية مع & 2 \\
\hline 69.6 & 174 & $r$ & MT & 10 & تتصف قيادات العمل بالاندية الرياضية & 3 \\
\hline 48 & 120 & TV & 11 & Ir & تتوازن مسئوليات قادة العمل بالاندية & 4 \\
\hline 78.4 & 196 & 7 & 10 & rq & 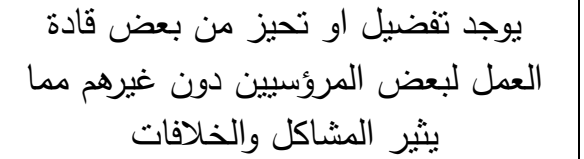 & 5 \\
\hline 57.6 & 144 & 1. & זr & V & يتوافر لمديري الاندية سلطات كافية لتتفيذ & 6 \\
\hline 69.6 & 174 & 10 & $\wedge$ & TV & يتم اختيار مديري الاندية طبقا للأققدية & 7 \\
\hline 54.4 & 136 & Ir & זr & 0 & تتظر الإدارة العليا لمديري الاندية بها نظرة & 8 \\
\hline 72.8 & 182 & ir & 1 . & rA & الرياضية يدعو إلىى الثعور بعدم الرضل الاديا & 9 \\
\hline 68 & 170 & 10 & 1. & ro & يوجد تحيز من قيادات الإدارة العليا لبعض الإندية & 10 \\
\hline 52 & 130 & YY & 17 & Ir & 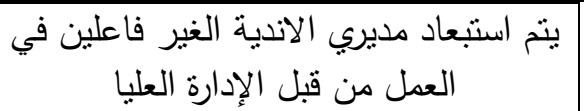 & 11 \\
\hline
\end{tabular}




\begin{tabular}{|c|c|c|c|c|c|c|}
\hline 77.6 & 194 & 11 & 7 & سז & يوجد إنراف مبانشر من القيادة العليا على المديرين & 12 \\
\hline 71.2 & 178 & $1 \pi$ & 1. & $T V$ & تهنم الإدارة العليا بمتابعة التشغيل وتتفيذ & 13 \\
\hline 81.6 & 204 & $\varepsilon$ & 10 & r & 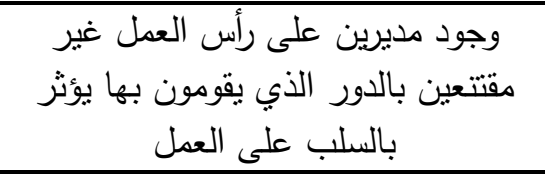 & 14 \\
\hline 50.4 & 126 & ro & IT & $1 \pi$ & مستوى تأهيل مديري الاندية بسمح لهم & 10 \\
\hline 64.8 & 162 & $\wedge$ & YA & $1 \leq$ & يتنت عقد الدورات التنريبية الفترية لمواكبة & 17 \\
\hline$\{\wedge . \wedge \varepsilon$ & 2564 & & & & & \\
\hline
\end{tabular}

$$
\text { يتضح من جدول ( .0 ) ما يلي : }
$$

- أن النسـبة المئويـة لأراء عينـة التعـرف على كلى الوضـع الـراهن في أسـلوب إدارة الانديـة

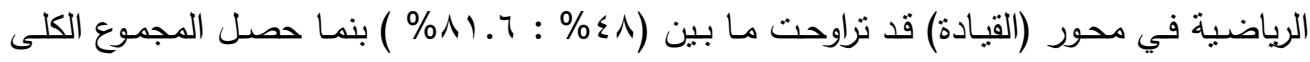

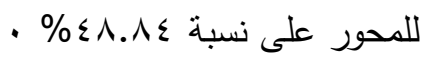

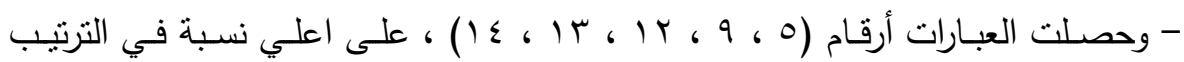

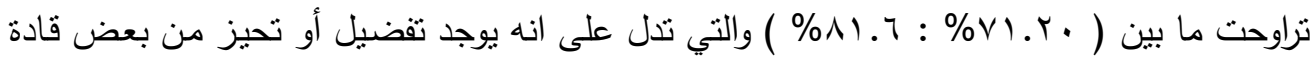

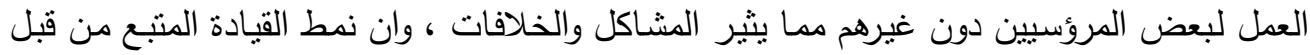

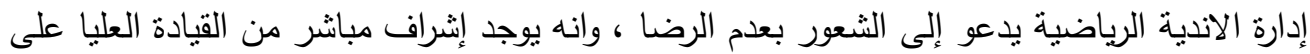

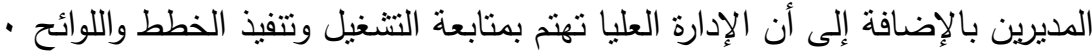

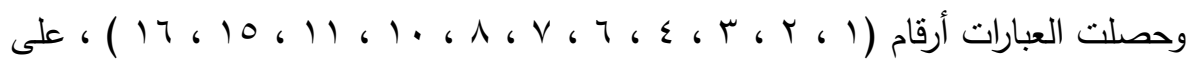

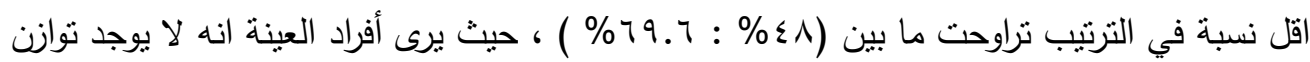
في مسئوليات قادة العمل بالاندية الرياضية مع سلطاتهم ، ولا يتوافر لمديري الاندية سلطات كافية لتتفيذ الإعمال المطلوبة ، وان اختيارهم يتم طبقا للاقدمية المطلقة ، وان الإدارة العليا تنظر لمديري

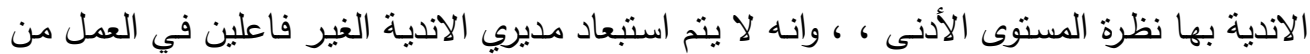

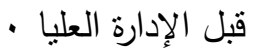


جدول (10)

الارجة المقدرة والنسبة المئوية لأراء عينة البحث في

المحور السادس : الرقابة

$$
0 .=\dot{0}
$$

\begin{tabular}{|c|c|c|c|c|c|c|}
\hline 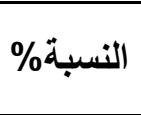 & المقدرة & $y$ & إلى حدا & نعم & العبارة & م \\
\hline 68 & 170 & 10 & 1. & ro & توجد رقابة من إدارة مديرية الثباب على أداء إدارة & 1 \\
\hline 49.6 & 124 & rA & V & 10 & يجرى سنويا تقويم أداء مؤسسي لإدارات وأقسام & 2 \\
\hline 44.8 & 112 & r. & 9 & 11 & للاقرجد مكتب فني متخص خطط تشغيل الاندية مدير الرياضبية & 3 \\
\hline 72.8 & 182 & r & $\wedge$ & $r q$ & 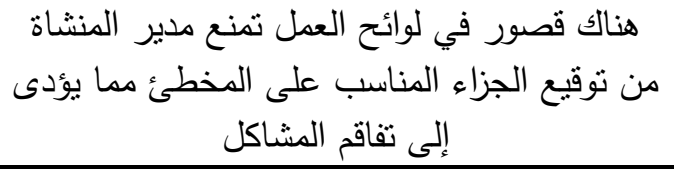 & 4 \\
\hline 44.8 & 112 & $r q$ & 11 & 1 & توجد رقابة من قبل وزارة الثباب والرياضة الاضدية الرياضية بصفة دورية & 5 \\
\hline 79.2 & 198 & 7 & $1 \varepsilon$ & $r$. & 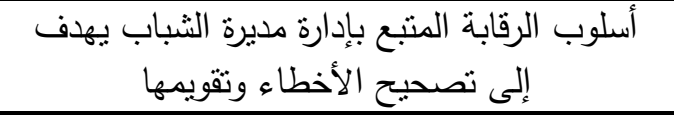 & 6 \\
\hline 83.2 & 208 & r & 18 & M & يوجد بإدارة المديرية أفراد مسئولين عن متابعة تتفيذ & 7 \\
\hline 43.2 & 108 & 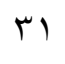 & 9 & $1 \cdot$ & يتم التقييم الفترى لأداء إدارة الاندية & 8 \\
\hline 72 & 180 & 1. & 10 & ro & 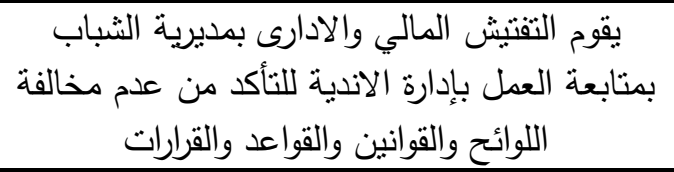 & 9 \\
\hline 54.4 & 136 & 17 & ro & 9 & تتابع مديرة الثباب تصرفات مديري الاندية تجاه & 10 \\
\hline 43.2 & 108 & rr & 0 & Ir & يغطى نظام الرقابة الحالي كافة الجوانب ( الإدارية - الفنية ) بمديرية الثباب & 11 \\
\hline 61.6 & 154 & $r$. & $\wedge$ & rr & 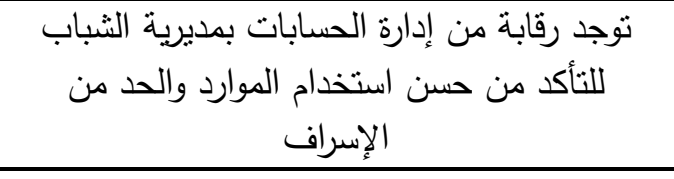 & 12 \\
\hline
\end{tabular}




\begin{tabular}{|c|c|c|c|c|c|c|}
\hline 57.6 & 144 & $1 \leq$ & ro & 11 & 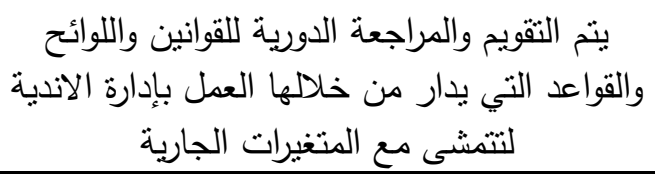 & 13 \\
\hline 62.4 & 156 & 11 & ro & $1 \leq$ & 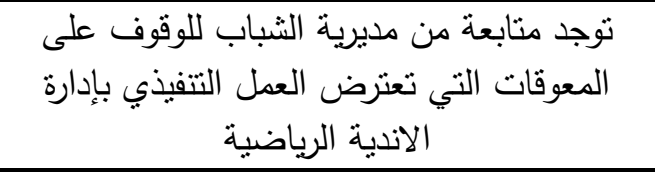 & 14 \\
\hline 67.2 & 168 & $\wedge$ & ro & IV & توجد وسائل قياس يمكن من خلالالها معرفة مدى المديق & \multirow[t]{2}{*}{10} \\
\hline$T . . Y V$ & 2260 & & & & & \\
\hline
\end{tabular}

$$
\text { يتضح من جدول ( } 101 \text { ) ما يلي : النبأ }
$$

أن النسبة المئوية لأراء عينة التعرف على على الوضع الراهن في أسلوب إدارة الاندية الرياضية

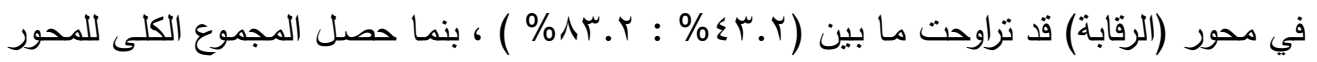

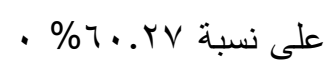

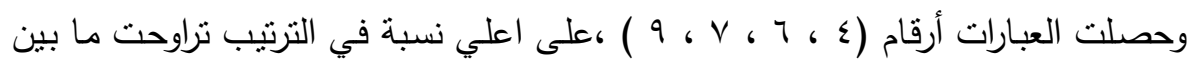

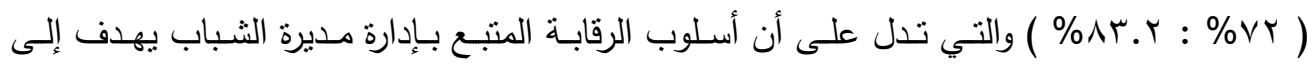

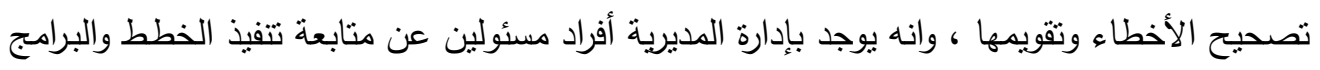

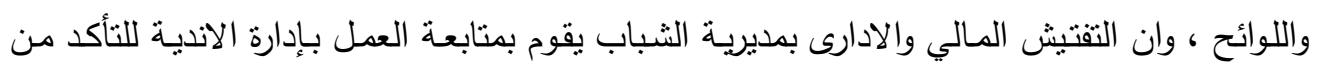

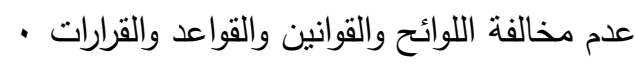

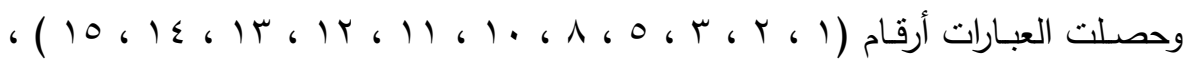

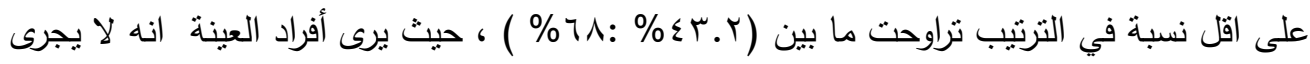

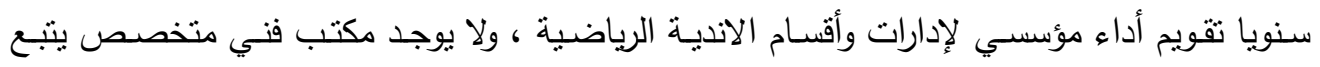

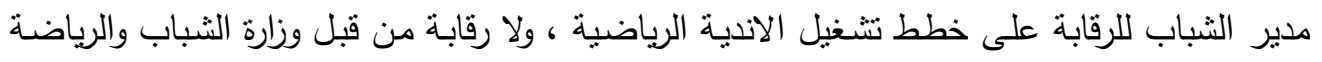

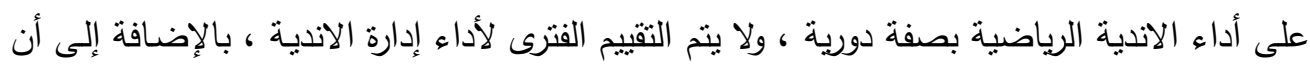

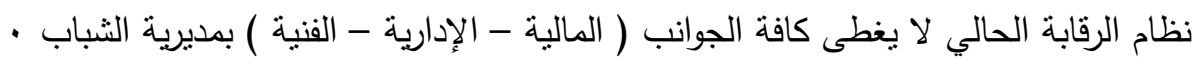

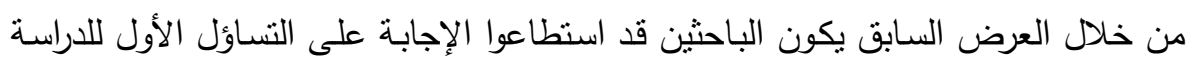

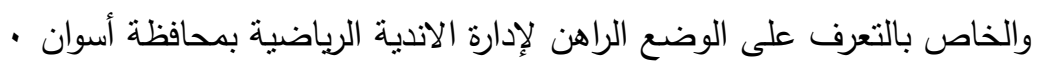
عرض ومناقثة نتائج إدارة الاندية الرياضية بنظام الخصخصة الجزئية بمحافظة أسوان 


$$
\text { جدول (بr) }
$$

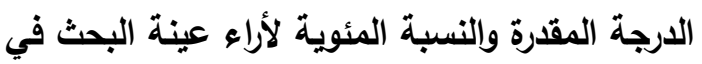

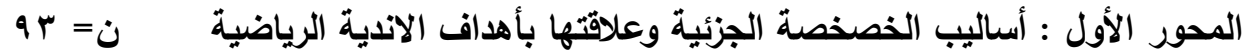

\begin{tabular}{|c|c|c|c|c|c|c|}
\hline النسبة\%\% & المقرجة & $y$ & الى حا & نعم & العبارة & م \\
\hline or.91 & 251 & rV & سז & r & تهدف الاندية الرياضية إلى نشر واستيعاب & 1 \\
\hline or.91 & 251 & TV & זr & $r r$ & 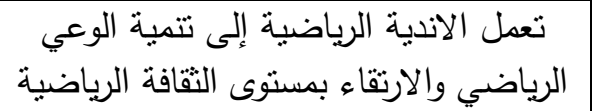 & 2 \\
\hline $79 . . r$ & 321 & $\overline{r r}$ & $r \wedge$ & $\varepsilon r$ & توجد أهداف اقتصادية للاندية الرياضية & 3 \\
\hline $01 . \wedge r$ & 241 & $\varepsilon r$ & rA & r & تتتاسب الأهداف الاقتصادية للاندية & 4 \\
\hline VT.rT & 341 & IV & rᄉ & $\varepsilon \wedge$ & 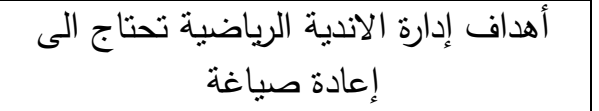 & 5 \\
\hline $0 \wedge . Y \wedge$ & 271 & rr & זr & rA & يقتنع مديري الاندية الرياضية والعاملين & 6 \\
\hline$\tau \leq . \Gamma$. & 299 & $\leq 0$ & 11 & $\varepsilon$. & تتناسب أهداف إدارة الاندية مع الإمكانيات & 7 \\
\hline $77 . \wedge 1$ & 311 & TV & r & $\varepsilon r$ & |تتاسب أهداف إدارة الاندية مع الإمكانيات & 8 \\
\hline $77 . \wedge 1$ & 311 & rY & זr & ऍ^ & ليتاسب نظام الخصخصة الجنية الجزئية للاندية & 9 \\
\hline $77 . \wedge 1$ & 311 & TV & זr & $\varepsilon r$ & 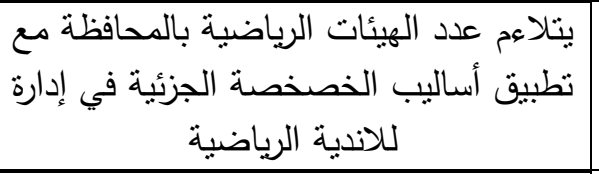 & 10 \\
\hline$T . . \Sigma \Gamma$ & 281 & TV & rᄉ & $r \wedge$ & 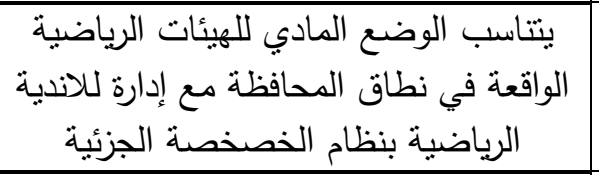 & 11 \\
\hline \multirow[t]{2}{*}{$01 . \wedge r$} & 241 & $\varepsilon r$ & rA & $r r$ & تتتلاءم أهداف الاندية الرياضية الحالية مع الجزئية & Ir \\
\hline & & & & & 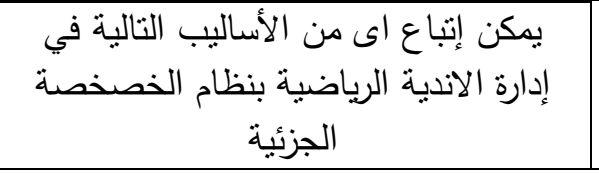 & \\
\hline
\end{tabular}




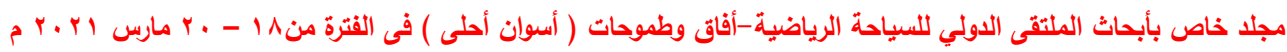

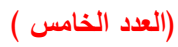

\begin{tabular}{|c|c|c|c|c|c|c|}
\hline $79 . . r$ & 341 & rt & $r_{\Lambda}$ & $\varepsilon r$ & مشروع الاستثمار المشترك & IT \\
\hline $79 . .4$ & 321 & TV & 11 & $\varepsilon \wedge$ & عقد الإدارة المشترك & $1 \leq$ \\
\hline מש & 321 & rr & 11 & or & التأجير & 10 \\
\hline$\wedge \wedge . r q$ & 411 & V & ir & $v \pi$ & أسلوب البناء والتملك والتتغيل ونقل الملكية & 17 \\
\hline 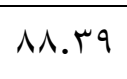 & 411 & r & rr & 71 & أسلوب البناء والتنملك والتتغيل B.O.T & IV \\
\hline 71.01 & VqVT & & & & & \\
\hline
\end{tabular}

أن النسبة المئويـة لأراء عينة إدارة الانديـة الرياضية بنظـام الخصخصـة الجزئيـة بمحافظـة

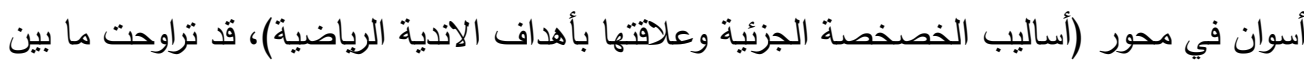

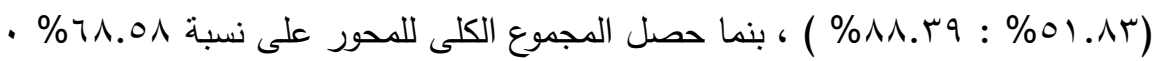

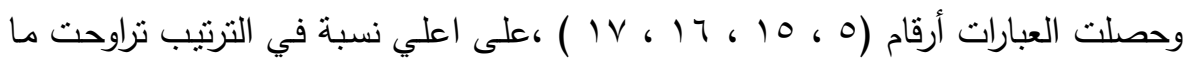

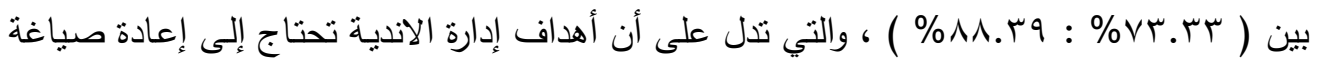

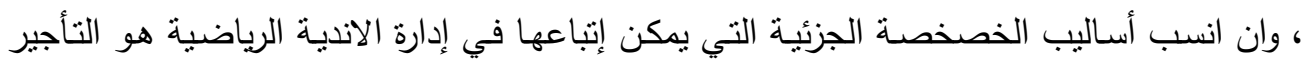

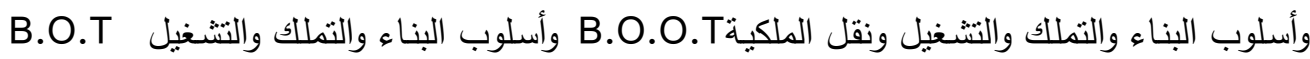

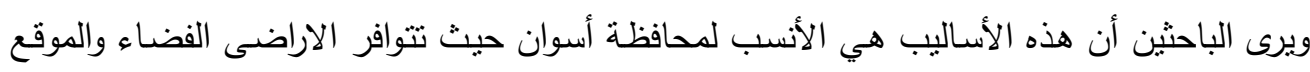

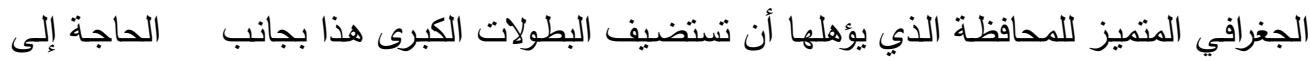

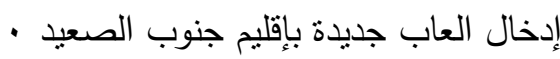

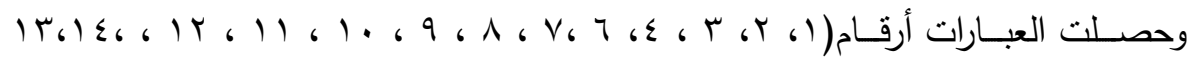

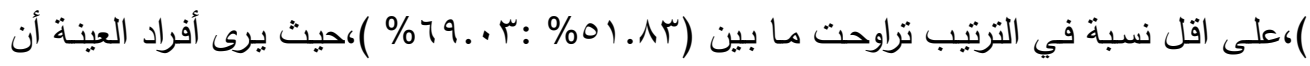
الاندية الرياضية لا تهدف إلى نشر واستيعاب مختلف الأنشطة الرياضية ، ولا تعمل إلى تتمية الوعي

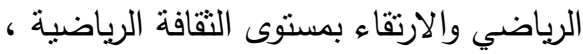

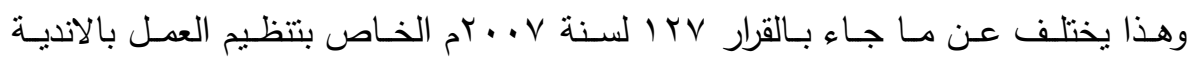

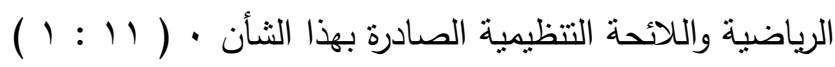

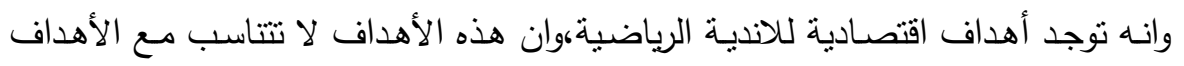

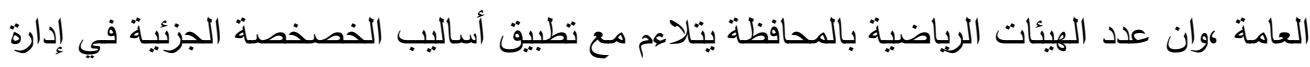

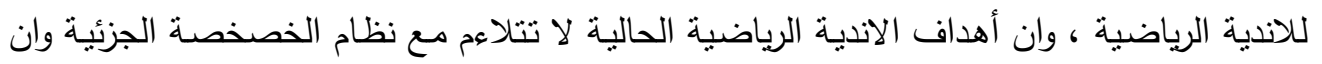


أساليب الاستثمار الششترك وعقد الإدارة هي اقل الأساليب التي يمكن أن تتماشى مع الاندية الرياضية

وهذا يتفق مع رأى الباحثين حسب خبرتهم في العمل بهذا المجال •

$$
\text { جدول (or) }
$$

\section{الارجة المقدرة والنسبة المئوية لأراء عينة البحث في}

المحور الثاني : الجوانب القانونية والإدارية عند تطبيق الخصخصة الجزئية

\begin{tabular}{|c|c|c|c|c|c|c|}
\hline النسبة\% & 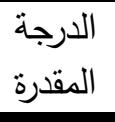 & V & الى حدا & نعم & 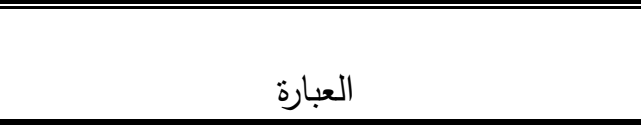 & r \\
\hline 75.48 & 351 & iv & r & or & 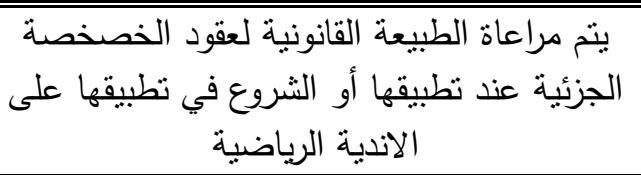 & 1 \\
\hline $1 \leqslant .90$ & 395 & • & ro & $0 \wedge$ & تكون الدولة هي المسئولة وصاحبة السيادة على العقود في نظم الخصئية & 2 \\
\hline 77.63 & 361 & Ir & rᄉ & or & تكون للحكومة سلطة عامة في ممارسة حق أبرام & 3 \\
\hline 74.19 & 345 & 1. & $\varepsilon$. & $\varepsilon r$ & يتم أبرام العقود بواسطة جهة الإدارة كطرف في & 4 \\
\hline 64.73 & 301 & Yr & rᄉ & سז & 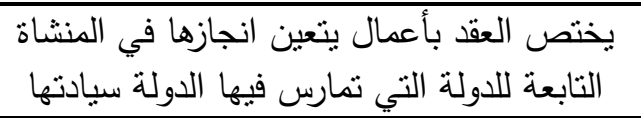 & 5 \\
\hline 75.48 & 351 & Ir & سז & $\leqslant \wedge$ & 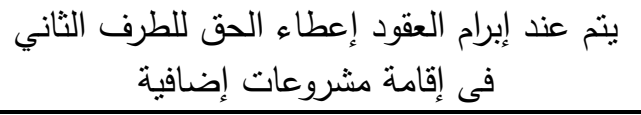 & 6 \\
\hline \multirow[t]{2}{*}{77.63} & 361 & iv & 11 & $0 \wedge$ & يعطى الحق للطرف الثاني فى إقامة أنشطة & 7 \\
\hline & & & & & تراعى المبادئ القانونية الأساسية الآتية عند إبرام & \\
\hline $11.9 \leq$ & 381 & V & rᄉ & $0 \wedge$ & مبدأ نتاسب ضمانات المخاطر & 8 \\
\hline $11.9 \leq$ & 381 & Ir & 11 & 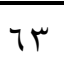 & ضمانات الإقراض & 9 \\
\hline 71.18 & 331 & iv & س & $\varepsilon r$ & فرض معايير للأذاء وكيفية الحفاظ عليها & 10 \\
\hline 64.73 & 301 & rr & rᄉ & 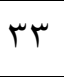 & سياسة التسعير & 11 \\
\hline 66.88 & 311 & $r V$ & r & $\varepsilon r$ & نظرية الظروف الطارئة & 12 \\
\hline
\end{tabular}




\begin{tabular}{|c|c|c|c|c|c|c|}
\hline & & & & & الإجراءات الإدارية التي يجب أن نقوم بها إدارة & \\
\hline 73.33 & 341 & ir & بر & $\leqslant r$ & دارسة ما قبل الجدوى من جانبها & 13 \\
\hline 1ᄉ.. $q$ & 391 & V & r & זיד & تعبين مؤسسة استثمارية فنية من اجل القيام & 14 \\
\hline 77.63 & 361 & Ir & rᄉ & or & 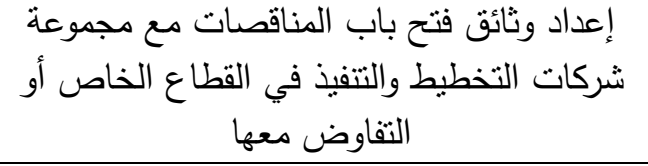 & 10 \\
\hline 79.78 & 371 & ir & 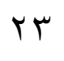 & $0 \wedge$ & إبرام المستثمرين الصفقة مع الإدارة & 17 \\
\hline 71.18 & 331 & IV & ז" & $\varepsilon r$ & 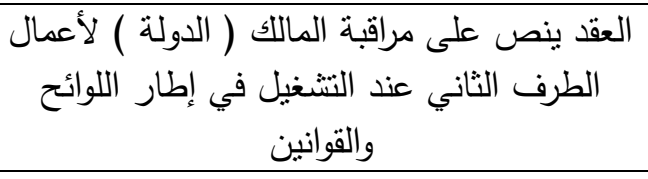 & IV \\
\hline Vo. $\leqslant 7$ & 5965 & & & & & \\
\hline
\end{tabular}

يتضح من جدول ( أم ) ما يلي :

أن النسبة المئويـة لأراء عينـة إدارة الانديـة الرياضية بنظـام الخصخصـة الجزئيـة بمحافظـة

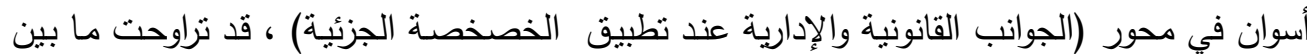

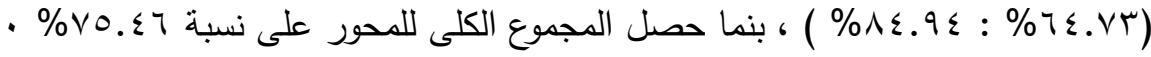

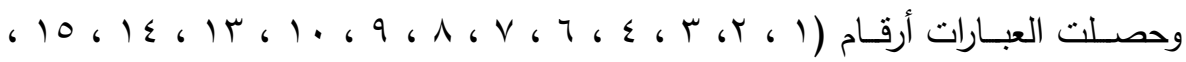

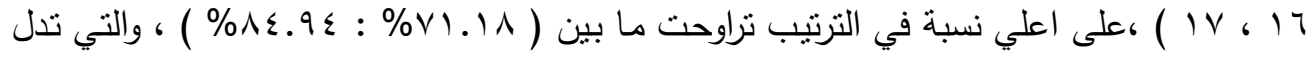

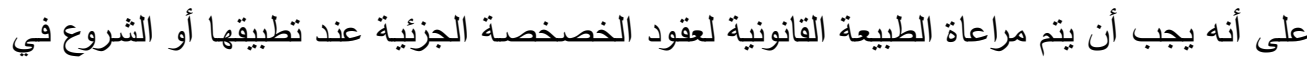

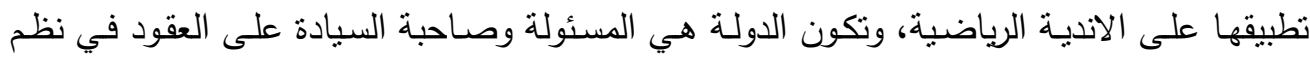

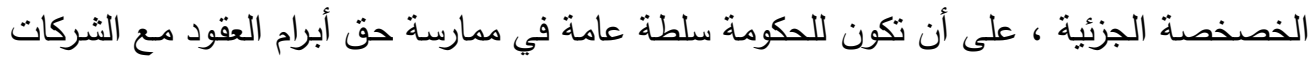

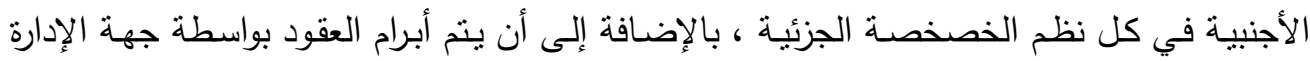

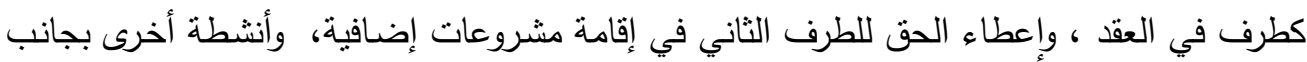
الأنشطة الرياضية ، وان يتضمن العقد مبدأ تتاسب ضمانات المخاطر وضمانات الإقراض، ومراقبة المالك ( الدولـة ) لأعمال الطرف الثاني عند التشغيل في إطـار اللوائح والقوانين وان تقوم الإدارة

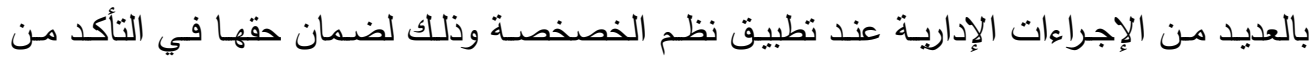

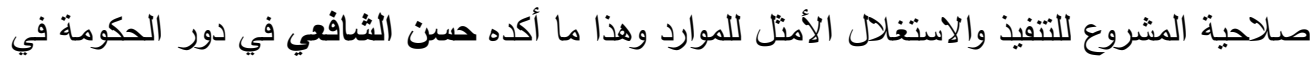

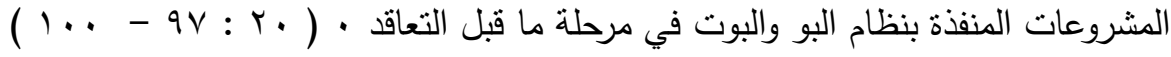


وأيضا يتفق هذا مع ما ذكره عوض شفيق عن ما يجب مراعاته عند صياغة التعاقدات

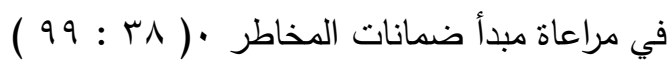

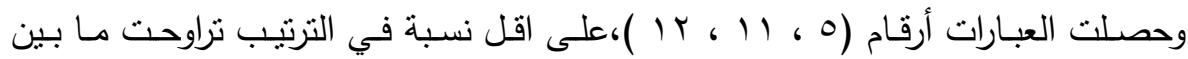

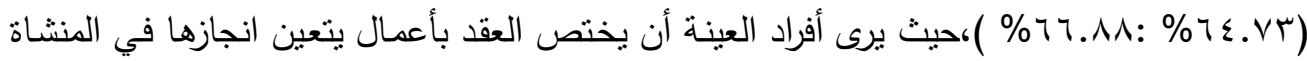

التابعة للاولة التي تمارس فيها الدولة سيادتها ومراعاة سياسة التسعير والظروف الطارئة

ويرى الباحثين أن هذا ضروري وحتمي حتى يضمن كل من المستثر والإدارة تتفيذ المشروع

على النحو المفروض وان يكون مطابق للمواصفات والثروط المتفق عليها -

ويذكر حسن الشافعي انه لابد أن تتصف عقود الخصخصة بالطبيعة القانونية وذلك من

خلال ولاية الدولة على عقود الخصخصة لأنها صاحبة الإقليم الذي يتم المشروع في نطاقه . (·r:

\section{جدول (ن)}

\section{الارجة المقدرة والنسبة المئوية لأراء عينة البحث في}

المحور الثالث : أساليب التسويق في نظام الخصخصة الجزئية

\begin{tabular}{|c|c|c|c|c|c|c|}
\hline 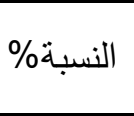 & 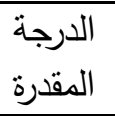 & ע & حدا ما & نعم & العبارة & r \\
\hline 75.48 & 351 & r & r & IV & يتم التعاقد مع إحدى شركات الدعاية والإعلان & 1 \\
\hline 79.78 & 371 & $0 \wedge$ & rt & ir & تستخدم مواقع الاندية في الدعاية والإعلان & 2 \\
\hline 66.88 & 311 & rr & 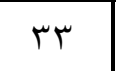 & rᄉ & توجد مميزات مالية تشجع على للقيام بالتسويق & 3 \\
\hline 69.03 & 321 & $\varepsilon r$ & $r \wedge$ & rr & يتم عمل المؤتمرات الصحفية عن أهم & 4 \\
\hline 73.33 & 341 & $\leqslant \Lambda$ & $r \wedge$ & IV & تستخدم الاعاية والإعلان لأهم الأحداث & 5 \\
\hline 66.88 & 311 & rᄉ & זr & rr & يتم استقطاب الشركات لتمويل الأنشطة & 6 \\
\hline 64.73 & 301 & Tr & rᄉ & rr & تعقد اتفاقيات مع مؤسسات إعلامية لرعاية & 7 \\
\hline 71.01 & 286 & Ts & سT & IV & تقام الحفلات الفنية بغرض جذب انتباه & 8 \\
\hline$\varepsilon 9.71$ & 231 & $\varepsilon V$ & r & 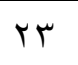 & تنتخدم الإدارة الحالية بعض أساليب التسويق & 9 \\
\hline
\end{tabular}




\begin{tabular}{|c|c|c|c|c|c|c|}
\hline & & & & & 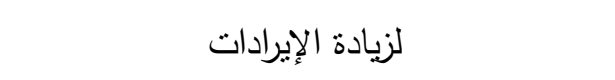 & \\
\hline 73.33 & 341 & $\varepsilon \wedge$ & ru & iv & توضع نتريعات تتجع الاستثمار في المجال & 10 \\
\hline 79.78 & 371 & or & r & $\mathrm{v}$ & توجد إدارة متخصصة للتسويق والاستثمار & 11 \\
\hline 69.03 & 321 & $\varepsilon r$ & ru & rt & يتم إجراء بحوث ودراسات خاصة بتسويق الرياضية مع المختصين & 12 \\
\hline 07.11 & 261 & $\varepsilon r$ & 11 & r & يوجد أفراد مسئولين عن التسويق & 13 \\
\hline$\varepsilon V .0 r$ & 221 & or & 11 & rr & تعقد دورات تدريية للعاملين بالاندية في مجال & 14 \\
\hline 77.63 & 361 & or & rA & ir & يتم تطوير اللشطاعم والكافيتريات وإسناد إدارتها & 10 \\
\hline$\wedge \varepsilon . .9$ & 391 & $0 \wedge$ & 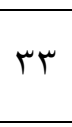 & r & تتشىء محلات تجارية وتأجيرها أو بيعها & 17 \\
\hline $7 \wedge . \varepsilon r$ & 5091 & & & & & \\
\hline
\end{tabular}

$$
\text { يتضح من جدول (عاه ) ما يلي : المئي }
$$

أن النسبة المئويـة لأراء عينـة إدارة الانديـة الرياضية بنظـام الخصخصـة الجزئيـة بمحافظـة

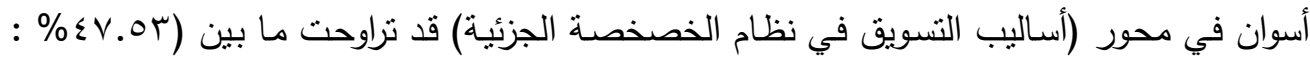

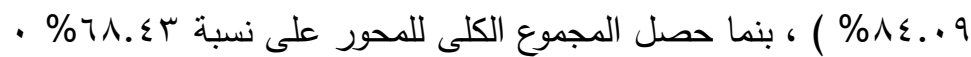

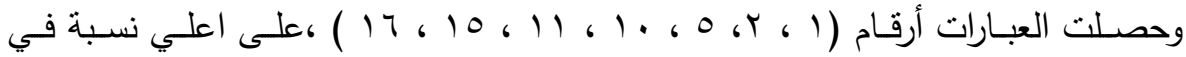

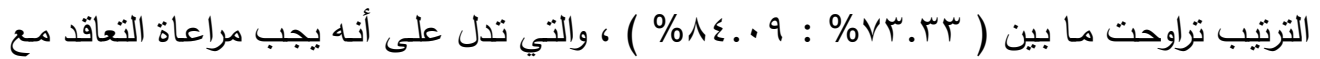
إحدى شركات الدعاية والإعلان والتخطيط للاحتياجات والاهتمام باستخدام مواقع الاندية في الدعاية

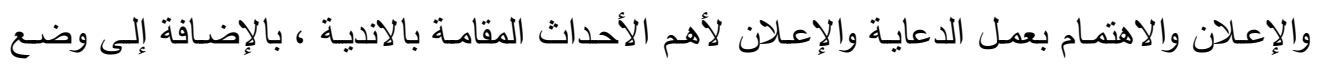

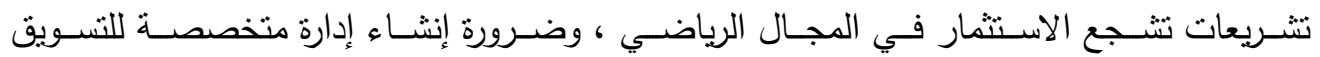

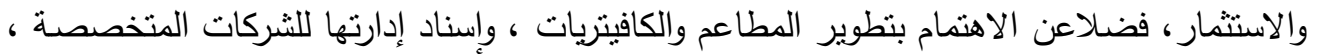

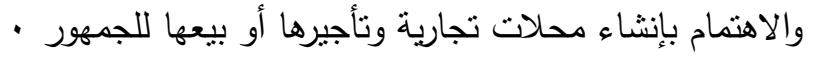

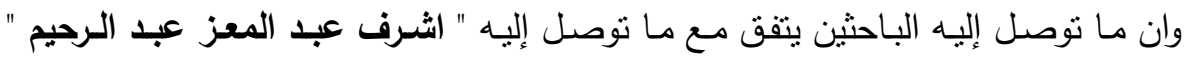

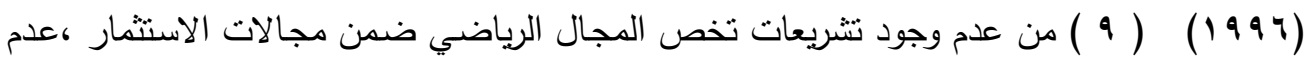

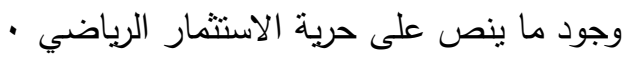


وأيضا مع ما توصل إليه " حسام رضوان كامل " ( . . F ) (9 1 ) من عدم وجود تشريعات

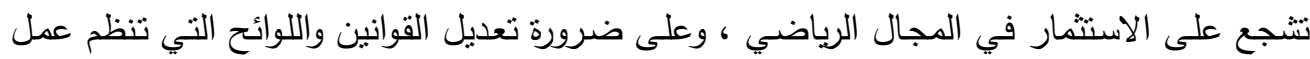

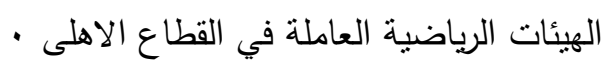

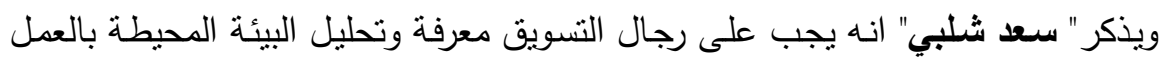

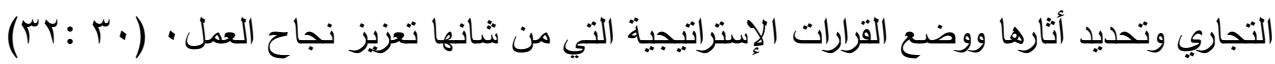

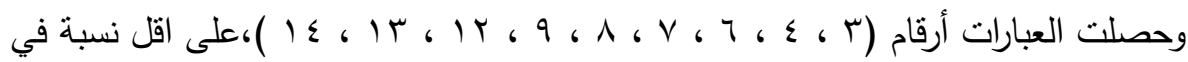

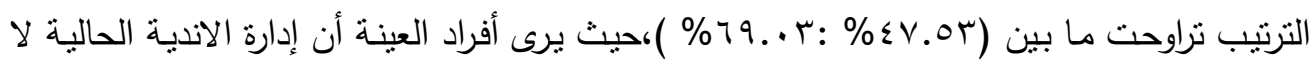

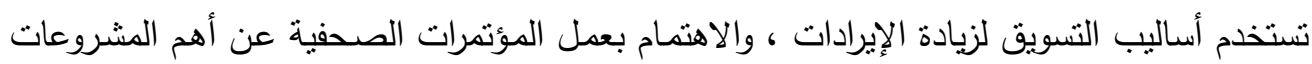

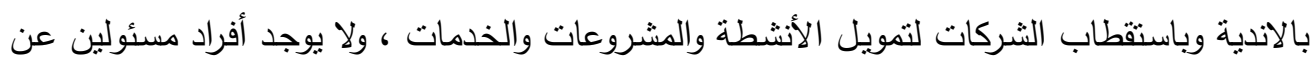

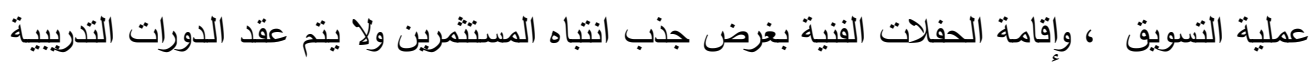

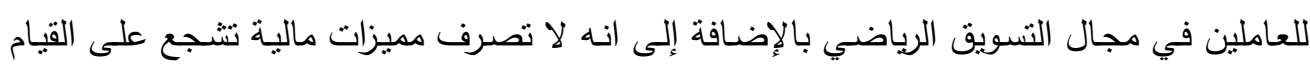
- بالتسويق

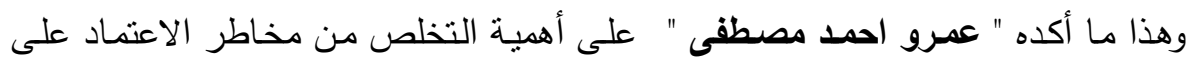

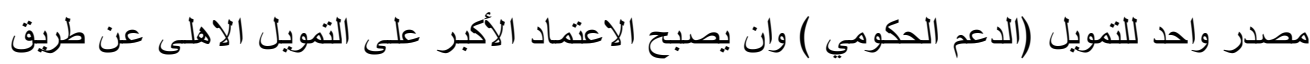

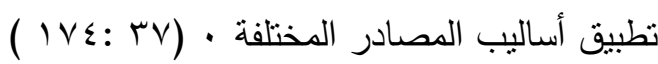

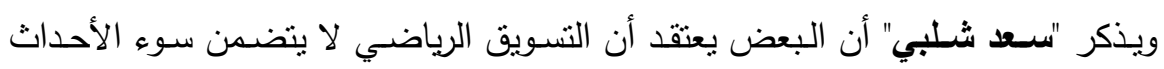

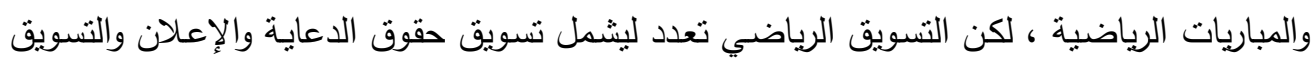

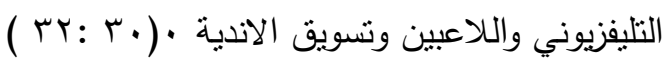

\section{جدول (00)}

الارجة المقدرة والنسبة المئوية لأراء عينة البحث في

المحور الرابع : التخطيط لإدارة الاندية الرياضية ل

\begin{tabular}{|c|c|c|c|c|c|c|}
\hline 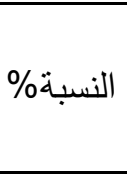 & الدقدرة & $\gamma$ & مدالى & نعم & 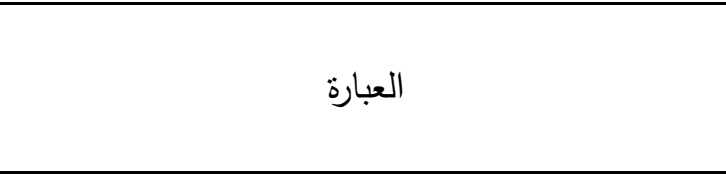 & م \\
\hline 71.18 & 331 & iv & 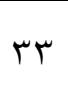 & $\varepsilon r$ & توضع خطط لإدارة الاندية الرياضية قبل التتفيذ بوقت & 1 \\
\hline Lr.r & 201 & $\leqslant V$ & rᄉ & $\wedge$ & تتتاسب الخطط الموضوعة مع أهداف الاندية الرياضية & 2 \\
\hline
\end{tabular}




\begin{tabular}{|c|c|c|c|c|c|c|}
\hline$\varepsilon r . r r$ & 201 & or & rᄉ & ir & تتسم الخطط بالمرونة لمواجهة اى ظروف طارئة & 3 \\
\hline 07.11 & 261 & m & rᄉ & r & تراعى الخطط الاستعانة بنظم الخصخصة الجزئية عند الإدارية & \\
\hline$\varepsilon r . r T$ & 201 & or & rᄉ & ir & يراعى عند التخطيط تطبيق اهداف الخصخصة الجزئية & \\
\hline 34.62 & 161 & $7 V$ & 11 & $\wedge$ & يتم وضع خطط لإدارة الاندية الرياضية طويلة المدى من من إلى & \\
\hline 64.73 & 301 & rr & rᄉ & r & الخطط الموضوعة يمكن تتفيذها فى حدود الإمكانيات & \\
\hline$\varepsilon r . r \mu$ & 201 & or & $r_{\Lambda}$ & $1 \pi$ & يوجد تتسيق بين خطط إدارة الاندية وبين خطط الهيئات & 8 \\
\hline 64.73 & 301 & rt & rᄉ & 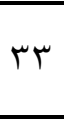 & بمكن ان يتم التتسيق بين خطط إدارة الاندية وبين خطط إلارية الإندية المركزية & 9 \\
\hline 49.67 & 231 & or & Ir & rA & تعمل خطط وبرامج إدارة الاندية الرياضية على زيادة عدد & 10 \\
\hline 45.37 & 211 & ov & M & r & يراعى عند التخطيط لإدارة الاندية الرياضية تحقيق رغبات & 11 \\
\hline $01 . \wedge r$ & 241 & or & $\wedge$ & 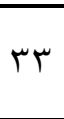 & يراعى عند التخطيط العمل على تسويق نظام الخصخصة & 12 \\
\hline 69.03 & 321 & rt & r^ & $\varepsilon r$ & التخطيط يعمل على زيادة عدد الاندية الرياضية فى نظام & 13 \\
\hline or.91 & 251 & $r v$ & ru & $r$ & يوجد تخطبط لرفع كافة الاندية الرياضية لجذب المستمرين & 14 \\
\hline$\varepsilon 9.71$ & 231 & $\varepsilon v$ & rr & $r$ & توضع خطط تدريبية كافية لتدريب العمالة بهذه الاندية & 10 \\
\hline 73.33 & 341 & ir & rᄉ & $\varepsilon r$ & تراعى الخطط الموجودة الظروف المالية لمستخدمي الاندية & 17 \\
\hline 04.01 & 3986 & & & & & \\
\hline
\end{tabular}

$$
\text { يتضح من جدول (00 ) ما يلي : }
$$

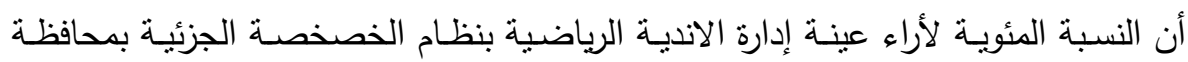

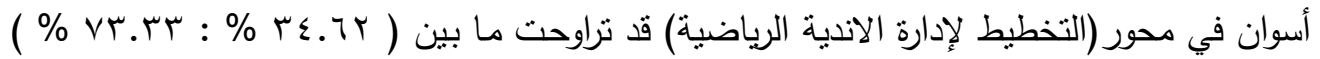

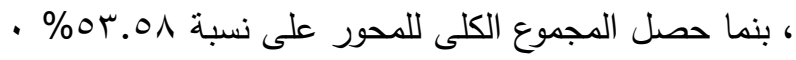




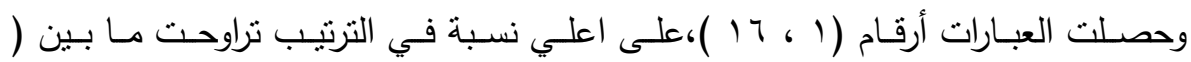

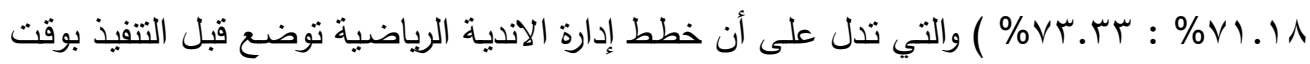

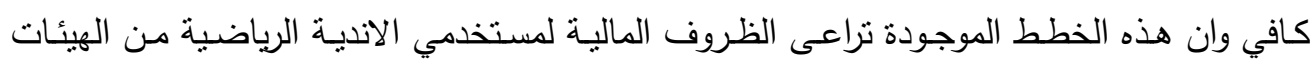
الرياضية .

وهذا مـا يؤكده " ميجنسـون Megginson " مـن أن الإستراتيجية هي عمليـة تحديد

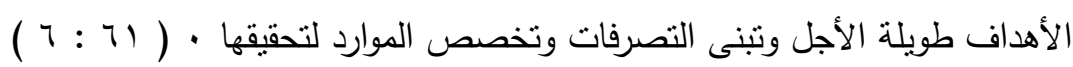

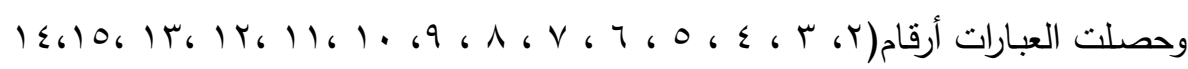

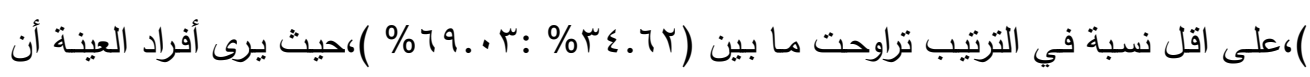

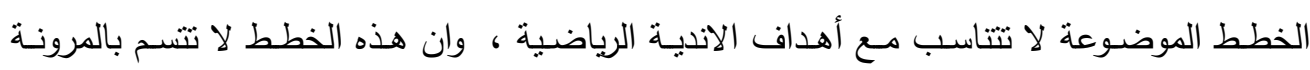

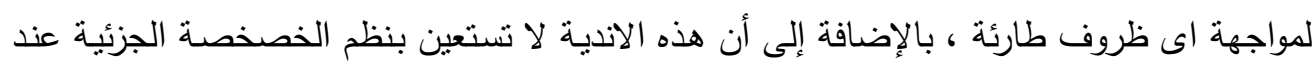

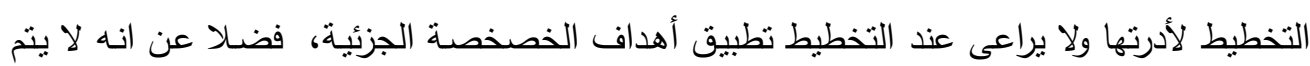

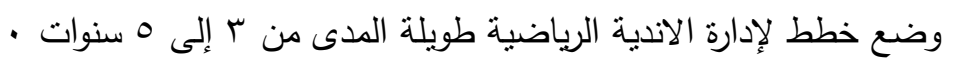

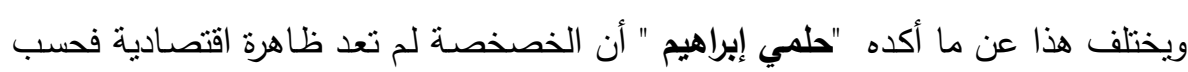

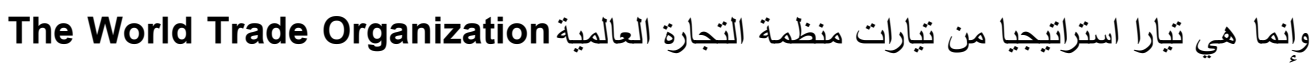

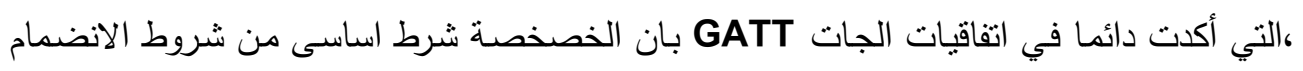
$(V: Y \varepsilon) \cdot(8)$

هذا ما أكده " طلعت اسعد عبد الحميد " أن الاندية والمؤسسات التي لا تضع الفكر

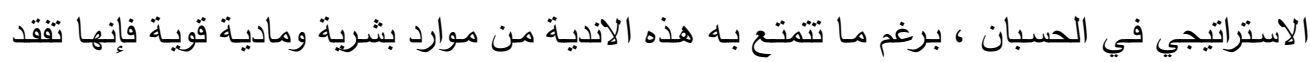

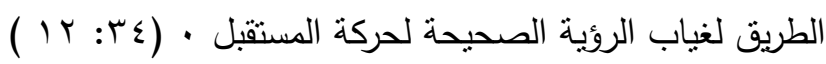
جدول (ه) الارجة المقدرة والنسبة المئوية لأراء عينة البحث في المحور الخامس : أساليب المتابعة والتقويم عند تطبيق الخصخصة الجزئية

\begin{tabular}{|c|c|c|c|c|c|c|}
\hline النسبة\% & 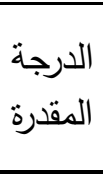 & $\gamma$ & مالى & نعم & العبارة & م \\
\hline 71.18 & 331 & IV & זr & $\varepsilon r$ & توجد رقابة من إدارة مديرية الثباب على أداء إدارة الاندية & 1 \\
\hline 75.48 & 351 & IT & זT & $\leqslant 1$ & يجرى سنويا تقويم أداء مؤسسي لإدارات وأقسام الاندية & 2 \\
\hline
\end{tabular}




\begin{tabular}{|c|c|c|c|c|c|c|}
\hline$\leq 0 . \mu \wedge$ & 211 & $\varepsilon V$ & זr & I & توجد رقابة من قبل وزارة الثباب والرياضةعلى أداء الاندية & 3 \\
\hline 04.91 & 251 & re & זr & r & أسلوب الرقابة المنبع بمديرية الثباب يهدف إلى تصحيح & 4 \\
\hline 79.78 & 371 & ir & rt & 01 & يوجد بإدارة المديرية أفراد مسئولين عن متابعة تتفيذ الخطط & 5 \\
\hline $11.9 \leq$ & 381 & $\bar{v}$ & $r \wedge$ & 01 & ينم التقييم الفترى لأداء إدارة الاندية & 6 \\
\hline 79.78 & 371 & v & זr & or & 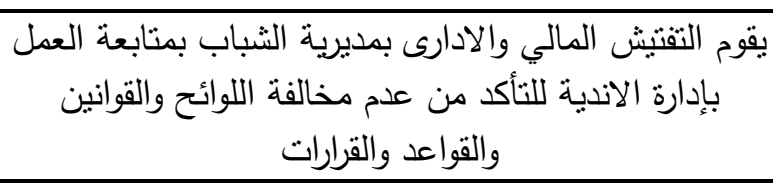 & 7 \\
\hline 71.18 & 331 & iv & זr & $\varepsilon r$ & تتابع مديرية الثباب تصرفات مديري الاندية تجاه العاملين & 8 \\
\hline$\varepsilon V .0 r$ & 221 & $\varepsilon \vee$ & rA & 11 & يغطى نظام الرقابة كافة الجوانب ( المالية - الإدارية - & 9 \\
\hline 75.48 & 351 & iv & rt & or & توجد رقابة من إدارة الحسابات بمديرية الثنباب للتأكد من المنداف & 10 \\
\hline 64.73 & 301 & rt & rᄉ & 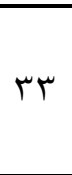 & 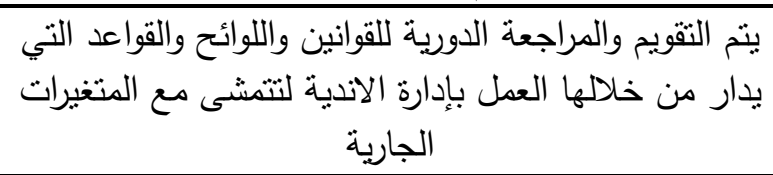 & 11 \\
\hline 62.58 & 291 & rr & $\varepsilon r$ & rA & 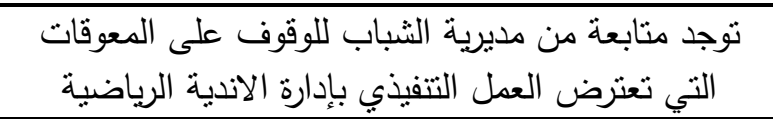 & 12 \\
\hline $01 . \wedge r$ & 241 & $\varepsilon \vee$ & 11 & $r_{\Lambda}$ & توجد وسائل قياس يمكن من خلالها معرفة مدى تحقيق & 13 \\
\hline 66.22 & 4003 & & & & & \\
\hline
\end{tabular}

$$
\text { بتضح من جدول ( }
$$

أن النسبة المئويـة لأراء عينة إدارة الانديـة الرياضية بنظـام الخصخصـة الجزئيـة بمحافظـة

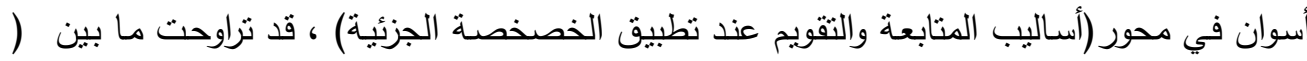

1

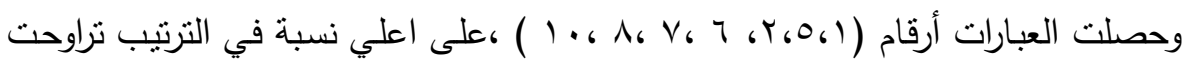

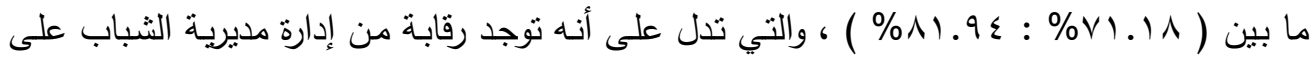

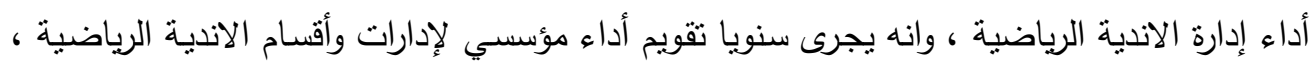

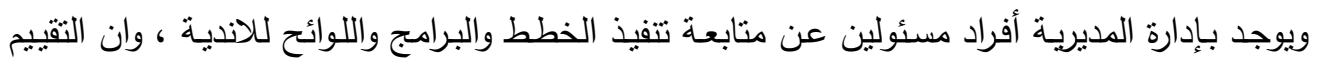


الفترى لأداء إدارة الاندية يتم بصورة جيدة ، وان مديرية الثباب تتابع تصرفات مديري الاندية تجاه العاملين بها - العزي

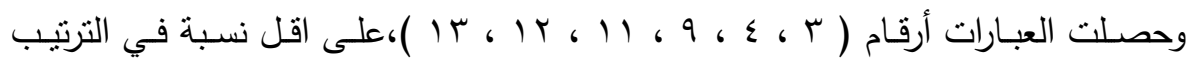

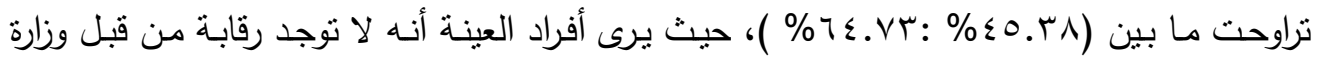

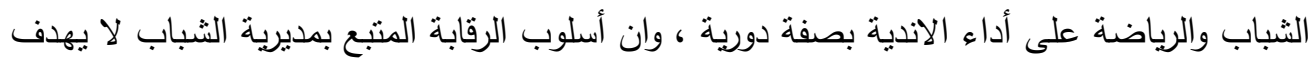
إلى تصحيح الأخطاء وتقويمها ، ولا يغطى نظام الرقابة كافة الجوانب ( المالية - الإدارية - الفنية )

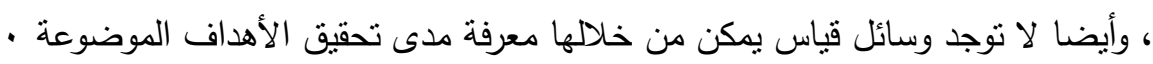

\section{جدول (ه)}

\section{الارجة المقدرة والنسبة المئوية لأراء عينة البحث في}

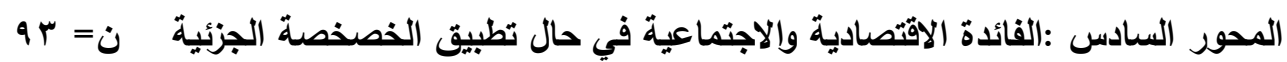

\begin{tabular}{|c|c|c|c|c|c|c|}
\hline النسبة\% & 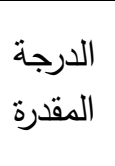 & $y$ & الى & نعم & العبارة & م \\
\hline Tr.tr & 290 & 11 & r人 & 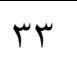 & تحسين ر الاقتصادي للاولة & 1 \\
\hline 75.48 & 351 & it & 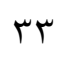 & $\varepsilon \wedge$ & استحداث أساليب جديدة للتمويل & 2 \\
\hline 69.03 & 321 & rr & rA & $\varepsilon$ & توفير الاستثمارات للارتقاء بمستوى الخدمات & 3 \\
\hline$O \wedge . Y \wedge$ & 271 & iv & "人 & rᄉ & مسايرة نظم خصخصة الأندية ودوري المحترفين & 4 \\
\hline 71.18 & 331 & rt & r & $\varepsilon \wedge$ & رفع مستوى أداء القيادات العاملة فى المجال & 5 \\
\hline 77.63 & 361 & ir & r^ & or & مسايرة المستويات العالمية والدولية في الاندية & 6 \\
\hline$\wedge 1.9 \leq$ & 381 & V & rA & $0 \wedge$ & استضافة البطولات والدورات العالمية & 7 \\
\hline ON.YA & 271 & iv & r人 & rA & مواجهة الأزمات المالية التي تمر بها الدولة فى الرياضة & 8 \\
\hline 77.63 & 361 & IT & rA & or & خفض تكاليف الاعم الحكومي والاستفادة في هذا الدعم في & 9 \\
\hline 66.88 & 311 & iv & س & 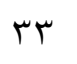 & رفع المستوى الاقتصادي للعاملين بهذه الاندية & 10 \\
\hline 07.11 & 261 & ret & rᄉ & rr & المساهمة في انتعاش أسواق المال المصرية & 11 \\
\hline 01.14 & 241 & $\varepsilon r$ & r^ & r & توفير فرص عمل جديدة & 12 \\
\hline 73.33 & 341 & iv & rA & $\varepsilon \wedge$ & فتح المجال أمام الصناعة الرياضية & 13 \\
\hline
\end{tabular}




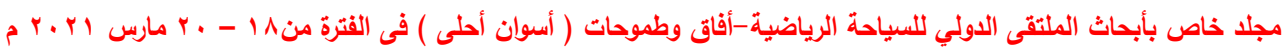

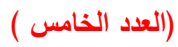

\begin{tabular}{|c|c|c|c|c|c|c|}
\hline 71.18 & 331 & iv & תب & $\varepsilon r$ & المساهمة في التتشيط للسياحة الرياضية & $1 \varepsilon$ \\
\hline 62.58 & 291 & re & r & rᄉ & التحول من مفهوم الخدمة الاجتماعية إلى مفهوم الربحية & 10 \\
\hline 77.63 & 361 & ir & ru & or & الاهتمام بالتسويق الرياضي للاندية & 17 \\
\hline 71.18 & 331 & ir & $\varepsilon r$ & rᄉ & التوسع في إنشاء الاندية الجديدة & iv \\
\hline 77.63 & 361 & $\mathrm{v}$ & rᄉ & $\varepsilon \wedge$ & تقليص دور الدولة على هذه الاندية & 11 \\
\hline 77.63 & 361 & IT & ru & or & ظهور الإدارة المحترفة & 19 \\
\hline 77.63 & 361 & 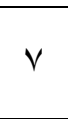 & r人 & $\varepsilon \wedge$ & 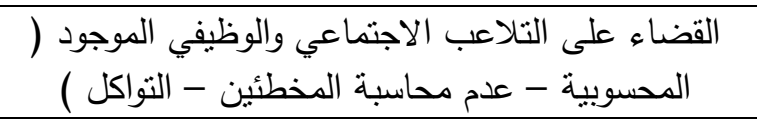 & r. \\
\hline 71.18 & 331 & ir & $\varepsilon r$ & rᄉ & ظهور العاب جديدة بالمواقع & r) \\
\hline 69.03 & 321 & rr & rA & $\varepsilon r$ & يمارس القطاع الخاص دور أكثر فاعلية في عملية التتمية & rr \\
\hline 69.80 & 7141 & & & & & \\
\hline
\end{tabular}

$$
\text { يتضح من جدول ( ov ) ما يلي : }
$$

- أن النسبة المئوية لأراء عينة إدارة الاندية الرياضية بنظام الخصخصة الجزئية بمحافظة

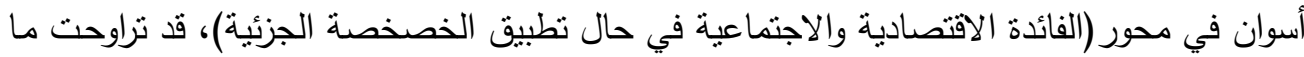

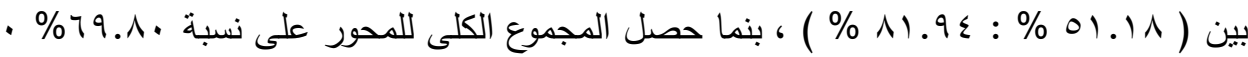

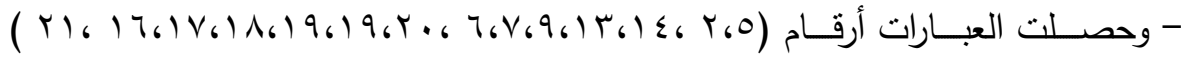

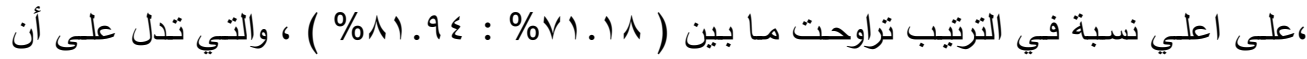

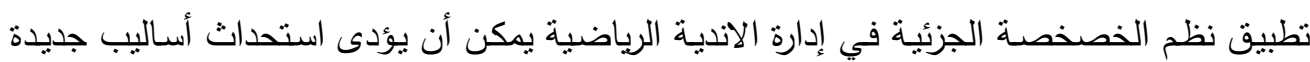

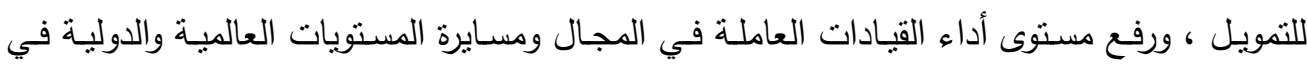
الانديـة ، بالإضـافة إلى إمكانيـة استضـافة البطولات والدورات العالميـة ، وخفض الدعم الحكومي الداتي

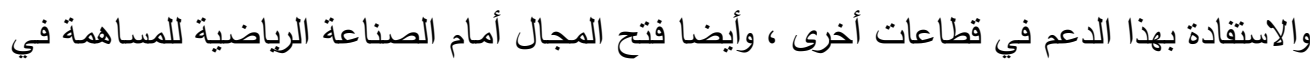

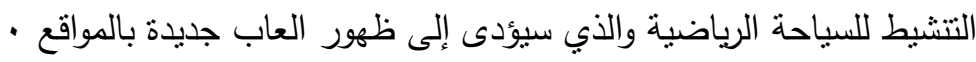

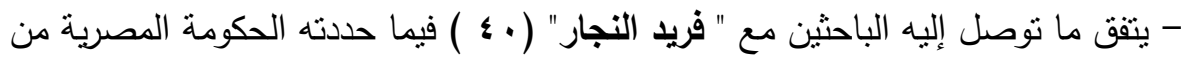

أهداف للخصخصة.

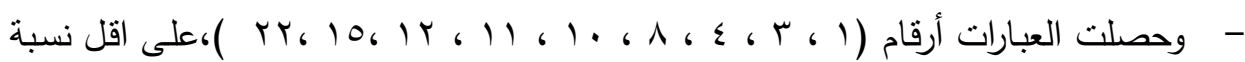

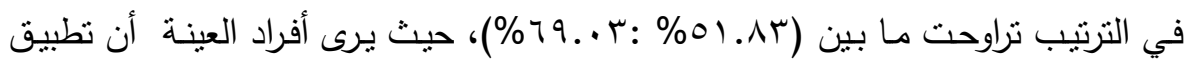
نظم الخصخصة الجزئية في إدارة الاندية الرياضية سيؤدى إلى حدا ما إلى تحسين الأداء 
الاقتصادي للاولة والمساهمة في انتعاش أسواق المال المصرية ، ولا يؤدى إلى توفير فرص عمل جديدة وسيؤدى إلى التحول من مفهوم الخدمة الاجتماعية إلى مفهوم الربحية التجارية

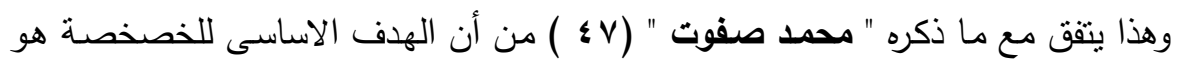

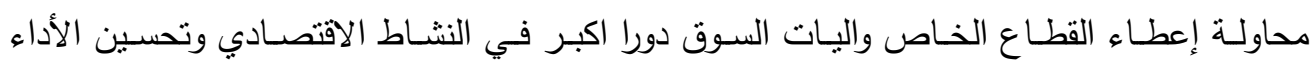

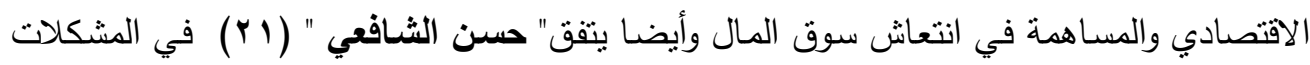

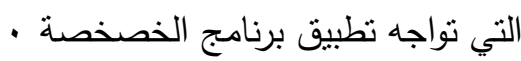

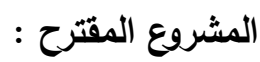
أن بنـاء المشروعات وتصميمها من الخصائص الهامـة لعمليـة التخطيط فهي تحتاج إلى الى

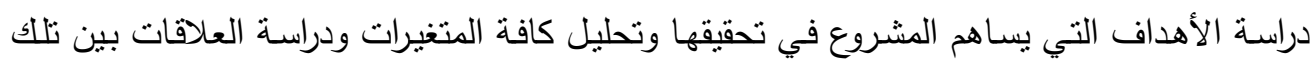
المتغيـرات واتبـع البـاحثين الخطوات الاتيـة لوضـع المشـروع المقترح لإدارة الانديـة الرياضـية بنظـام

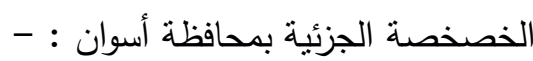
1- دراسة البيئة المستفيدة من المشروع المقترح لخصخصة الهوان الاندية الرياضية r- دراسة خصائص الجهات المستخدمة لهذه الاندية r- تحديد العناصر المؤثرة في المشروع المقترح ع- احتيار نوع المشروع المقترح 0- وضع تصور لموضوع المشروع وصياغة البرامج الزمنية 1- - إخراج المشروع المقترح في صورته النهائية

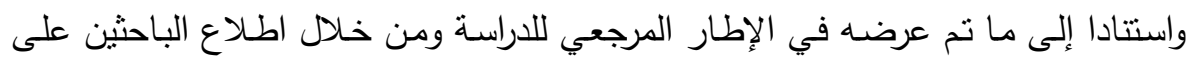

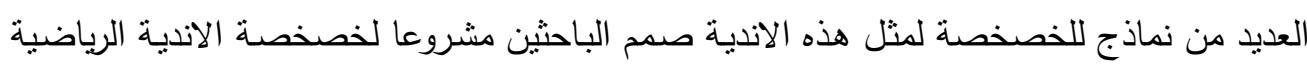

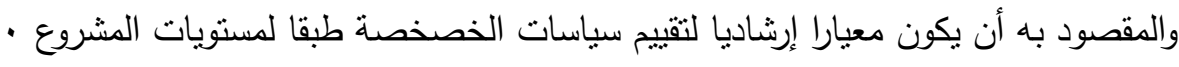

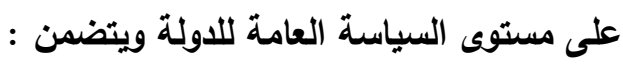
مدى الالتزام السياسي لتطبيق الخصخصة في مجال الاندية للاولة ولفئن ؛ الرياضية

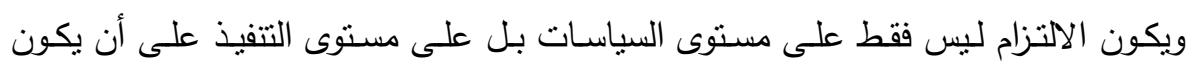

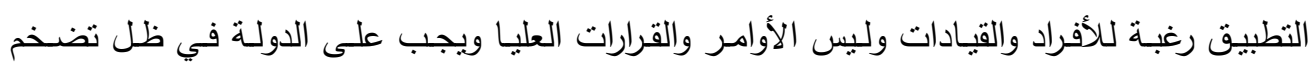


ميزانيات الصرف على النشـاط الرياضـي أن نسعى جاهدة لتوجيـه غالبيـة الصرف إلى القطاعـات

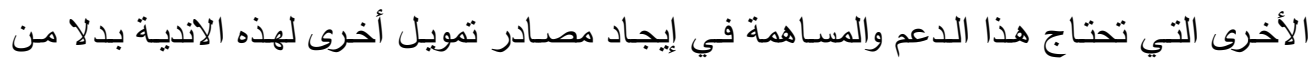

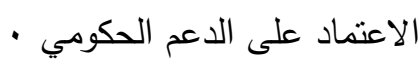
الإطار القانوني والتشريعي للأندية الرياضية :

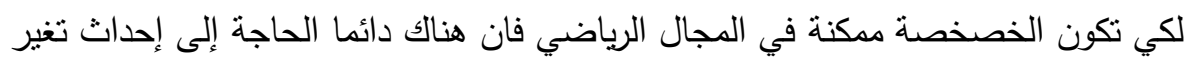

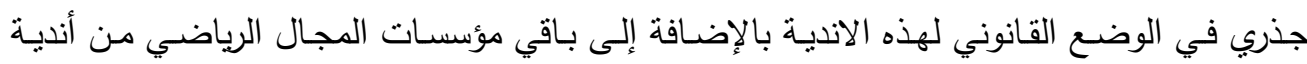

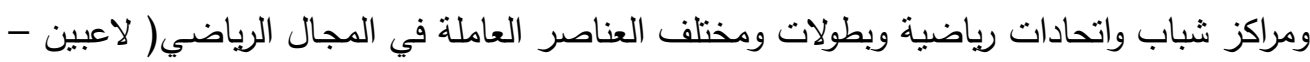

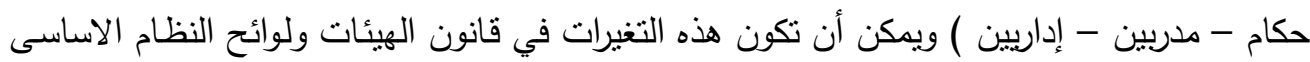

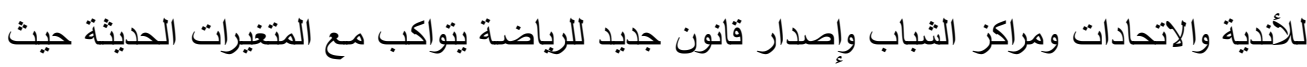

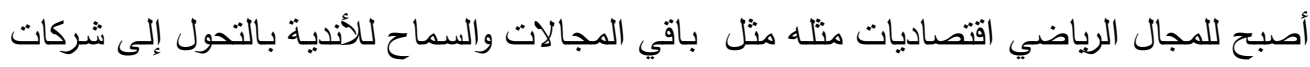

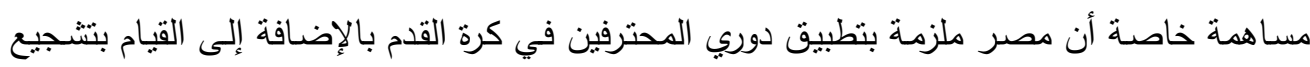

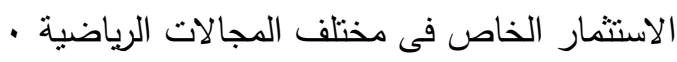
وضع خطة شاملة للخصخصة في الاندية الرياضية :

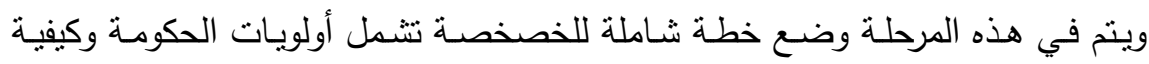

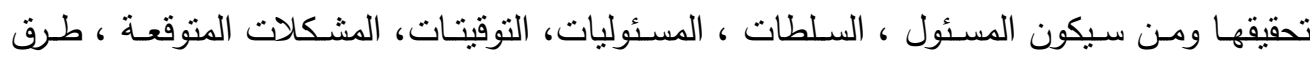

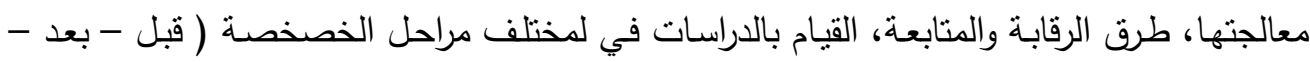

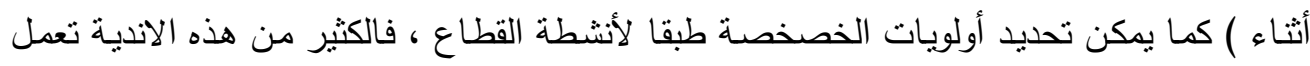

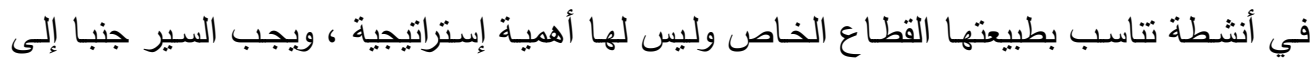

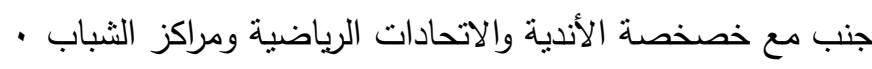
تحديد الهيكل التظيمي المسئول عن التنفيذ :

يجب تشكيل هيكلا تتظيما مسئولا عن تتفيذ البرنامج يتبع تكنون مسئوليته الرئيسية تتفيذ

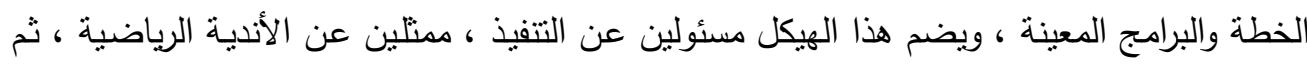

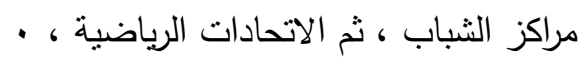
التصور المقترح لإدارة الأندية الرياضية بنظام الخصخصة الزياضة ، الجزئية بمحافظة أسوان وضع خطة تسويقية للاندية الرياضية :

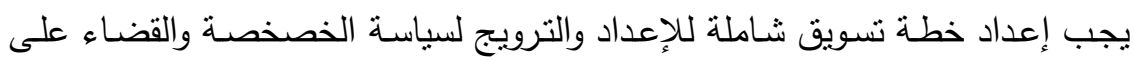
السلبيات التي ظهرت بعد تطبيق البرنامج في الثركات وبعض المشروعات بنات بنظام الخصخصة الكلية

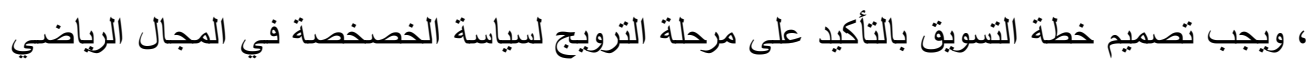


يليها تقديم برامج تسويقية معينة وخطط عمل تتضمن تقاصيل عن الانديـة المراد إداراتها بنظـام

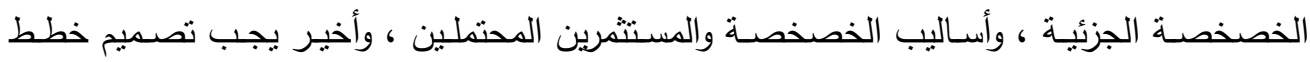

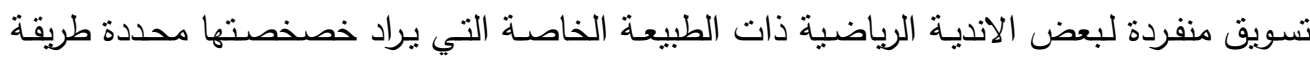

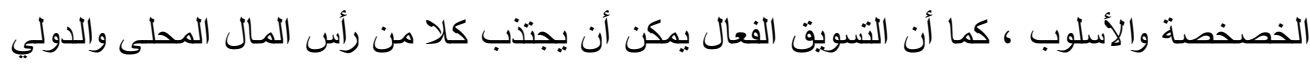

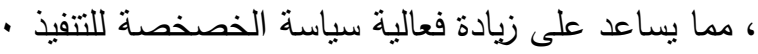
وضع خطة إعلامية لمساندة خصخصة الاندية الرياضة :

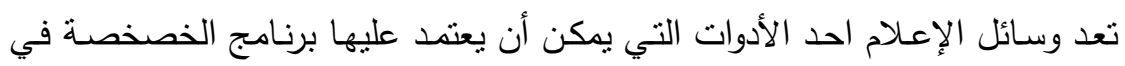

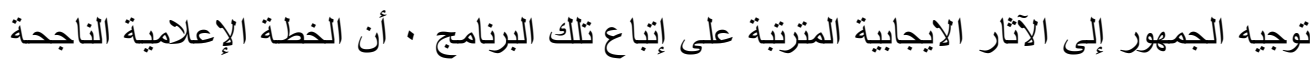

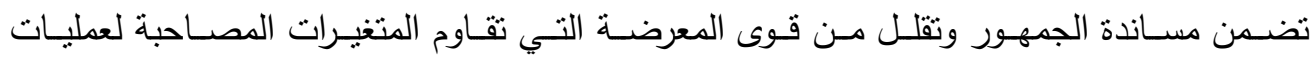

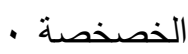

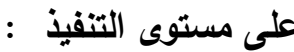

هنـاك بعض الجوانب التـي تقوم عليها سياسـة الخصخصـة في المجـال الرياضـي وهـى

كالاتى :

\section{توضيح برنامج الخصخصة للعاملين في الاندية الرياضية :}

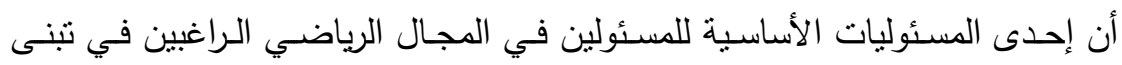

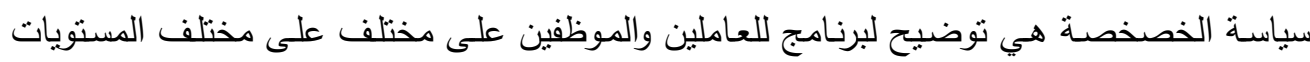

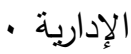

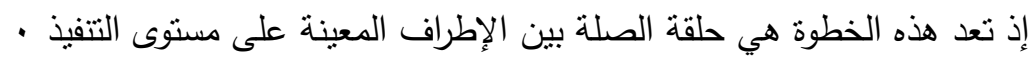

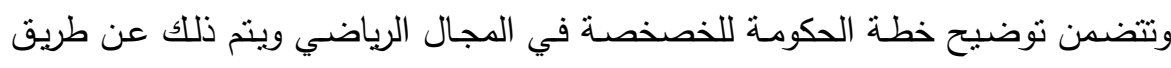

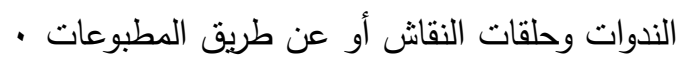
أن المواجهة والحوار الفعال والاتصال المباشر من شانهم زيادة الوضوح والحد من الأسئلة

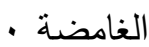
ومن ثم فهم يقللوا من فرص المقاومة ويزيدوا من فرص الرغبة في الخصخصة على مختلف • مسنويات التنفيذ إنشاء شبكة اتصالات فعالة :

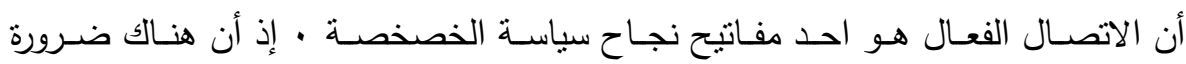

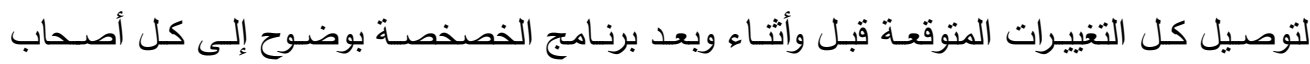


ومتخذي القرار فالاتصال الفعال أمر مطلوب على مختلف المستويات وهناك الحاجة إلى توصيل الاتى : -

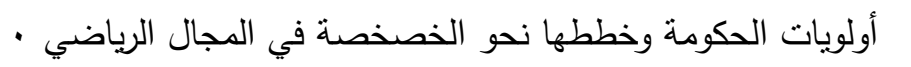

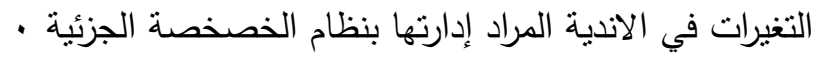

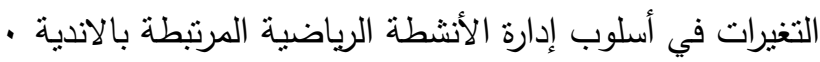

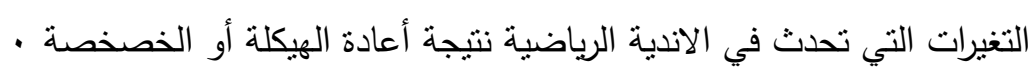

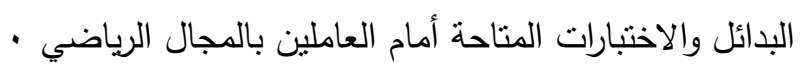

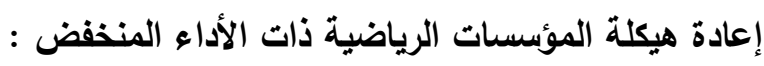

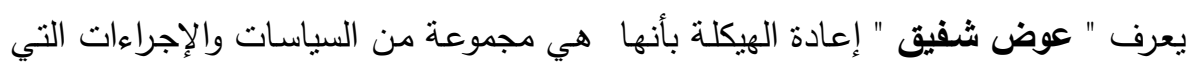

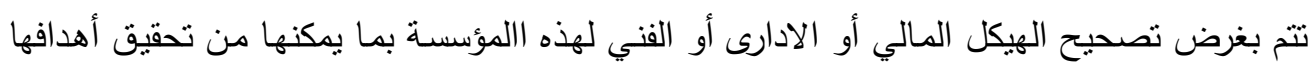

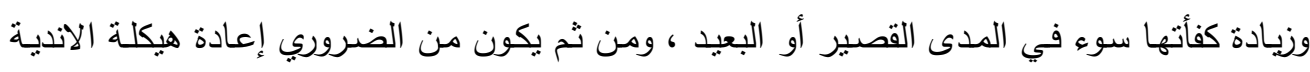

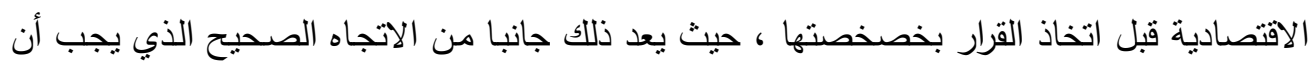

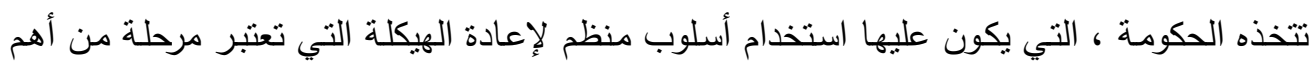

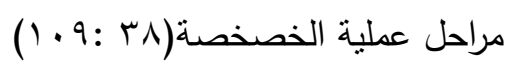
وهناك مدخلان رئيسيان لإصـلاح المؤسسـات الرياضية احدهما مركزي على مستوى

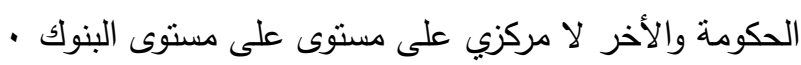

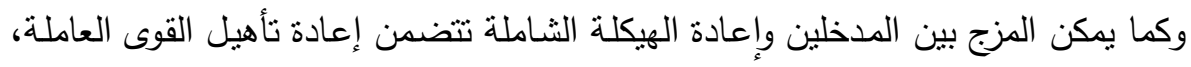

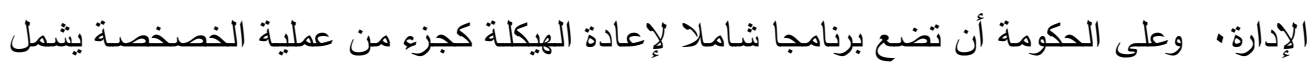

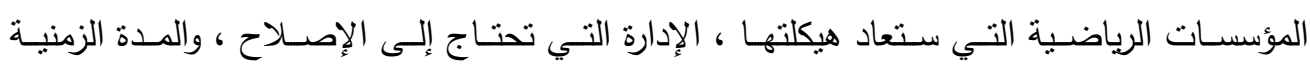

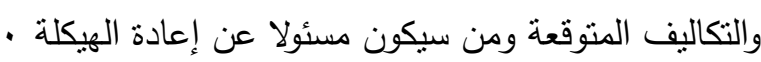
تحديد طرق وأساليب الخصخصة لكل مؤسسة رياضة :

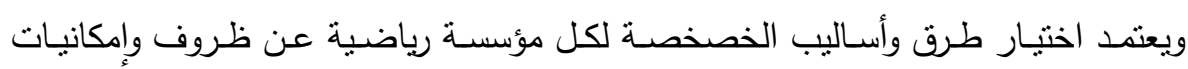

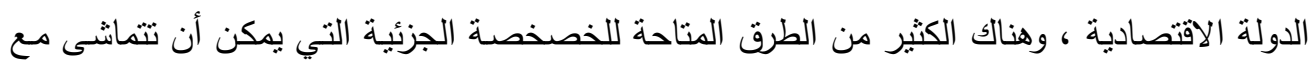

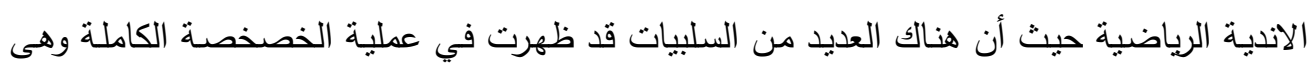

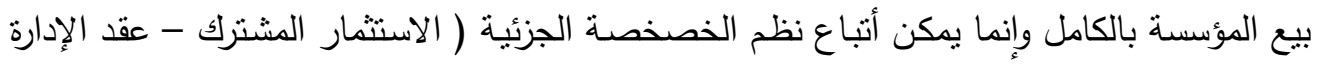

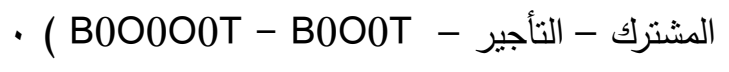
توفير المعلومات الرقابية : 
يعتبر توفير المعلومات الدورية احد أساليب الرقابة على برنامج الخصخصة فهي ضرورية

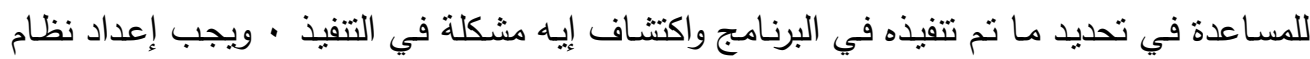

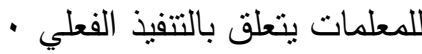

من خلال العرض السابق يكون الباحثين قد استطاعوا الإجابة على التساؤل الثاني للاراسة وهو ما المشروع المقترح لإدارة الاندية الرياضية بنظام الخصخصة الجنئينية بمحافظة أسوان . | الاستنتاجات

في ضوء أهداف البحث وتحقيقا للإجابة على تساؤلاته وفى حدود مجتمع وعينة البحث ومن

خلال عرض ومناقثة النتائج وتحليلها وتفسيرها توصل الباحث إلى الاستتناجات التالية : -

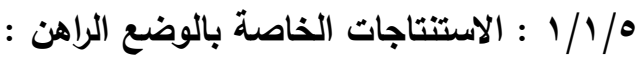
1/1/1/0

أهداف إدارة بالأندية الرياضية غير محددة وواضحة للعاملين ·

عدم تتاسب الأهداف الموجودة مع الإمكانيات المادية والبشرية المتاحة .

ل لا توجد معايير توضح مدى تحقيق الأهداف الخاصة بإدارة بالأندية

في التخطيط :

عدم وجود خطط لإدارة بالأندية الرياضية طويلة المدى من ؟ إلى ه سنوات.

لا نساعد الخطط والبرامج على زيادة عدد المترديين ولا على تحقيق رغبات غالبية الهيئات

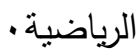

$$
\text { لا يوجد تخطيط لزيادة عدد هذه بالأندية . }
$$

خطط التدريب الموجودة غير كافية بالنسبة للعمالة بهذه بالأندية .

في التنظيم : ،وجد هيكل تتظيمي لإدارة بالأندية الرياضية ·

لا يوجد بالهيكل النتظيمي جميع الوظائف التي تحتاجها إدارة بالأندية . عدم تطبيق أساليب الإدارة الحديثة في الإدارة والتشغيل • 
لا توجد إدارة متخصصة في الاستثمار والتسويق •

في الإمكانيات :

توجد حوافز شهريا للعاملين بالأندية تعتمد على ما يتحقق من دخل.

الطرق والأساليب المالية المتبعة حالياً للمنشآت الرياضية لا تفي بالغرض التي وضعت من

- أجلها ألمان

لا يتم توزع أرباح في نهاية العام المالي على العاملين ·

عدم تتاسب اللائحة المالية الموجودة مع الهيئات التي تستخدم هذه بالأندية .

لا تهتم القيادة العليا بنوفير الإمكانيات اللازمة للاستخدام .

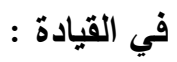

يتم اختبار مديري بالأندية طبقا للأقدمية المطلقة وليست الكفاءة • مستوى تأهيل مديري بالأندية لا يسمح لهم بقيادة الإفراد بنجاح · لا نتوازن مسئوليات قادة العمل بالأندية الرياضية مع سلطاتهم ·

عدم استبعاد مديري بالأندية الغير فاعلين في العمل من قبل الإدارة العليا .

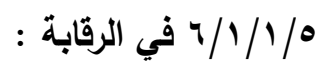

" توجد رقابة من إدارة مديرية الثباب على أداء إدارة بالأندية الرياضية . توجد رقابة من إدارة الحسابات بمديرية الثباب للتأكد من حسن استخدام الموارد والحد من

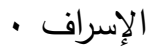

لا توجد رقابة من قبل المجلس القومي للرياضة على أداء بالأندية الرياضية بصفة دورية.

نظام الرقابة لا يغطى الحالي كافة الجوانب ( المالية - الإدارية - الفنية ) ·

r/l/0 الاستنتاجات الخاصة بالمشروع المقترح : 
1/\%/1/0 في أساليب الخصخصة الجزئية وعلاقتها بأهداف بالأندية الرياضية .

لا تعمل بالأندية الرياضية إلى تتمية الوعي الرياضي والارتقاء بمستوى الثقافة الرياضية .

يتتاسب نظام الخصخصة الجزئية للمنشات الرياضية مع المستوى الاقتصادي للسكان يتتاسب الوضـع المـادي للهيئات الرياضية الواقعة في نطاق المحافظة مـع إدارة للمنشـات الرياضية بنظام الخصخصة الجزئية .

تعد أسـاليب الخصخصـة الجزئيـة ( التأجير - البنـاء والتملكلك والتتــغيل ونقل الملكيـة B.O.O.T

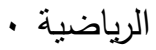

r/r/1/0

يتم مراعاة الطبيعة القانونية لعقود الخصخصة الجزئية عند نطبيقها أو الثروع في تطبيقها

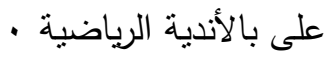
يتم أبرام العقود بواسطة جهة الإدارة كطرف في العقد تكون الدولة هي المسئولة وصاحبة السيادة على العقود في نظم الخصخصة الجزئية. تعيين مؤسسة استثمارية فنية من اجل القيام بدراسات الجدوى.

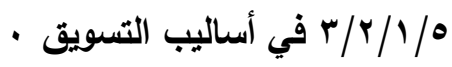
لا تستخدم الإدارة الحالية أساليب التسويق لزيادة الإيرادات . عدم وجود أفراد مسئولين عن التسويق • لا يتم عقد دورات تدريبية للعاملين بالأندية في مجال التسويق الرياضي · لا توجد مميزات مالية تتجع على القيام بالتسويق •

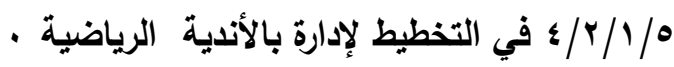


توضع خطط لإدارة بالأندية الرياضية قبل التنفيذ بوقت كافي •

لا يوجد تخطيط لرفع كافة بالأندية الرياضية لجذب المستمرين •

عند التخطيط لا يراعى العمل على تسويق نظام الخصخصة الجزئية .

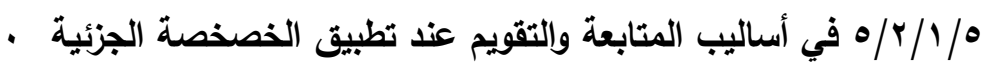

توجد رقابة من إدارة مديرية الثباب على أداء إدارة بالأندية الرياضية.

أسلوب الرقابة المنبع بمديرية الثباب لا يهذف إلى تصحيح الأخطاء وتقويمها .

لا نوجد وسائل قياس يمكن من خلالها معرفة مدى تحقيق الأهداف الموضوعة.

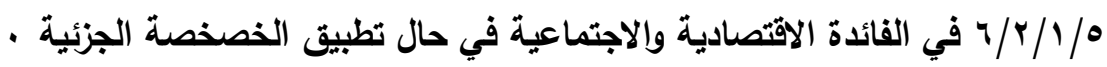

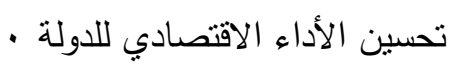

استحداث أساليب جديدة للتمويل . - أل

فتح المجال أمام الصناعة الرياضية.

خفض الدعم الحكومي والاستفادة في هذا الدعم في قطاعات أخرى.

r/0 r التوصيات

في ضوء ما أظهرته نتائج هذه الدراسة من سلبيات وايجابيات في الوضع الراهن في إدارة الأندية الرياضية بتقدم الباحث بالتوصبات التالية :

تطبيق المشروع المقترح لإدارة الأندية الرياضية بنظام الخصخصة الجئة الجزئية بمحافظة أسوان

العمل على وضـع إستراتيجية طويلـة الأجل تمثنل الإطـار الذي ينولى رسم معالم الحركة

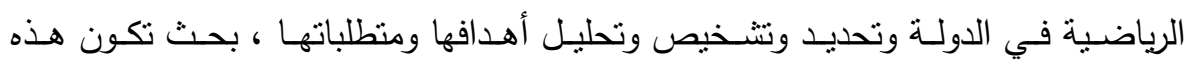

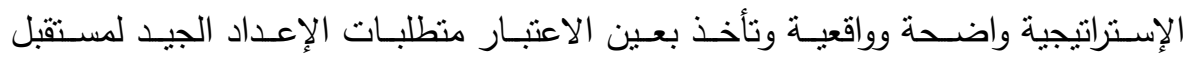

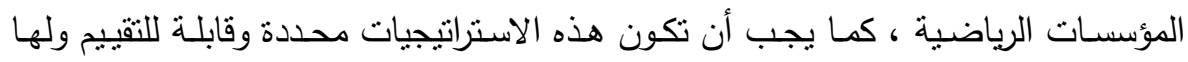
خطط ومراحل ثانوية وذلك لتامين تتسيق البعد الزمني في التنفيذ . 
التأكد عل ضرورة أن ترسخ المؤسسات الرياضية الفكر الاقتصادي المطروح الواعي بأهمية

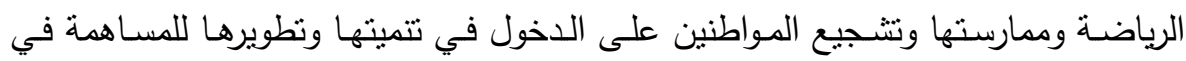
تحقيق الأهداف التنموية للدولة.

إعادة هيكلة المنظومة الرياضية على أساس مفهوم التحديث والتطوير وإمكانية النمو والتقدم الغير متتاهي لتحسين استغلال مواردها الاقتصادية والاجتماعية في الحفاظ على درجاتها لهابها نحو الأفضل.

التأكد على أن خصخصـة بالأنديـة الرياضية لا تعنى تحويلها إلى مؤسسـا ت استتمارية

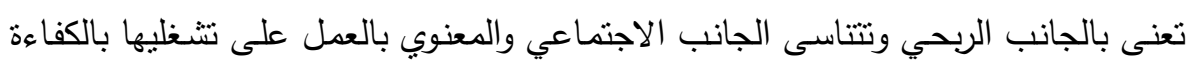

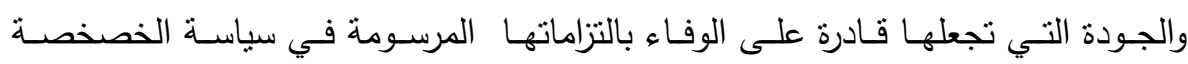
للمؤسسات الرياضية .

دعم وتعزيز التوجه نحو الخصخصة لأهداف إستراتيجية في علاج الأوضـاع الاقتصادية

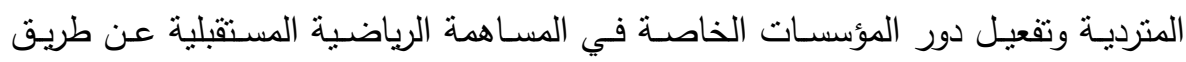

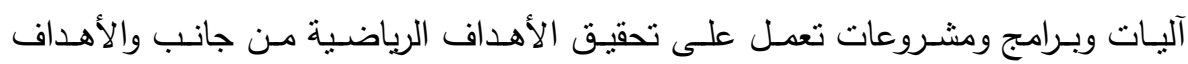
التتموية والاقتصادية من جانب أخر · اقتراح الباحثين أن يتم تكوين لجنة من :

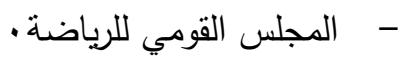
- - ل - لجنة الثباب بمجلسي الثعب والثورى. - - - الخبراء في المجال الرياضي والاقتصادي.

وذلك لدراسة مشروع الخصخصة الجزئية للمنشآت الرياضية وفقا لجدول الأعمال الاتى : التشريعات التي تحتاج إلى إعادة صياغة . الأساليب التي يمكن استخدامها في الخصخصة بالأندية الرياضية. كيفية التعامل مع بعض القضايا المرتبطة بالخصخصة. 
كيفية تشجيع الاستثمار الخاص على الدخول مجال إدارة بالأندية الرياضية. وضع الضوابط القانونية الني تكفل خصخصة بالأندية الرياضية بصورة سليمة والتي تكفل

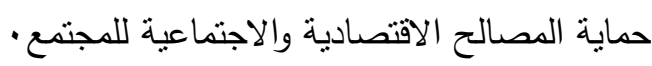
التشريعات القانونية والضريبية.

إناحسة الفرصـة للاستثمار في المجال الرياضي وذلك من خـلال تشجيع الدولة للمستثمرين

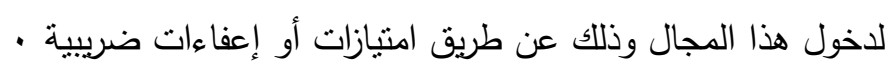
الاعتماد على الإدارة المحترفة في إدارة الأندية الرياضية.

التوسع في استخدام عقود الإيجار في الأندية الرياضية كمقدة للخصخصة الجزئية . صباغة بنود العقود مع الثركات المسئولة وان وتوضع شروط محددة بمكن معها إمكانية

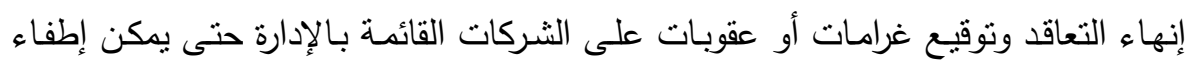

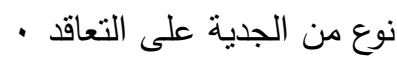




\section{أولا : المراجع العربية}

التحـول إلـى القطــاع الخـاص ، تجـارب عربيـة فـي خصخصـة احمد صقر عاشور :

المشـروعات العامـة ، المنظمـة العربيـة للتنميـة الإداريـة ، القـاهرة - م 199V。

الآثار الاقتصادية والاجتماعية لخصخصة الأندية الرياضية ،دراسـة : أحمد عبد الفتاح احمد :

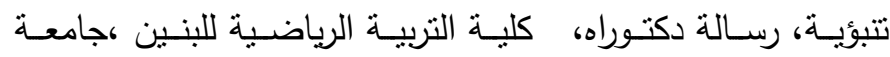

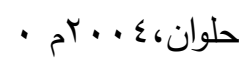

اقتصـاديات الإدارة ، الإسـكندرية ، مركـز التتميـة الإداريـة ، كليـة

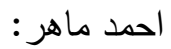
التجارة ، جامعة الإسكندرية ، 1990 م م

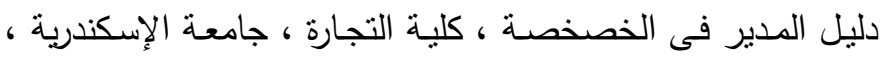

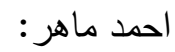

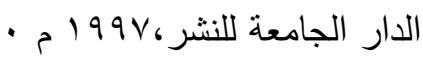
الخصخصة بين النظرية والتطبيق ، الدار الجامعة للطباعة والنشر

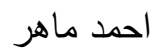
الإبراهيمية ، الإسكندرية ، 1990 م

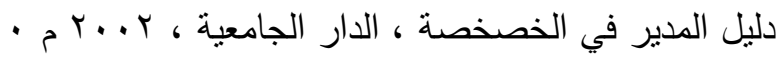
ومحمد صالح الحناوى:

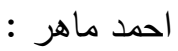

الأعـلام الرباضـي، دراسـة علميـة للتحربـر الرياضـي في الصـحافة أديب خضور : n

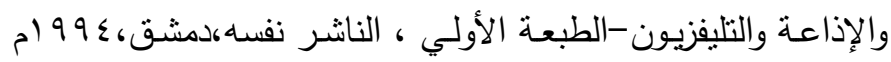

نموذج مقترح لإدارة العلاقات العامـة في المجال الرياضي ، رسـالة

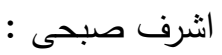

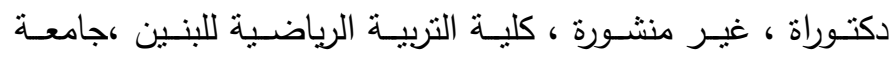

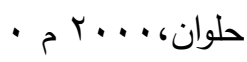
تقويم اقتصـاديات الأنديـة الرياضية المصرية، رسـالة دكتوراة، ،كلية اشرف عبد المعز عبد الرحيم : التربية الرياضية الرياضية للبنين ،جامعة حلوان، 999 ام التهبة لائحة القواعد المنظمة لإدارة وتتغيل المنشات الرياضية وملحقاتهاالمجلس القومي للرياضة :

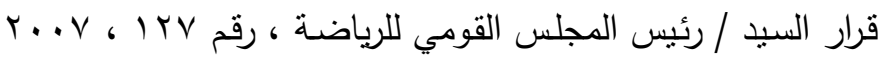
تخصيص المؤسسات العمومية ( تونس ) ص (آ- بحث من كتاب المنجى بودرارة 
: جهود معوقات التخصص في الدول العربية ، 1999 م م

الرياضــة مظاهرهـا السياسـية والاجتماعيـة والتربوبـة ، الـدار العربيـة اليونسكو :

أسـاليب الخصخصة الجزئية بنظامي البو والبوت بالأندية الرياضية تأمر شعبان عبد الباقي : في جمهورية مصر العربية،رسالة ماجستير ،كلية التربية الرباضية

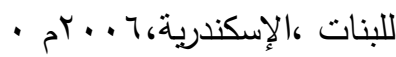
التفوق الإداري وكيفيـة اكتسـاب المهارات الأساسـية،الطبعة الأولي

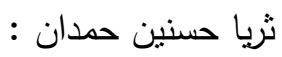

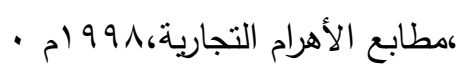

السياسـة العربيـة للثباب والرياضـة، مجلس وزراء الثباب ، القاهرة

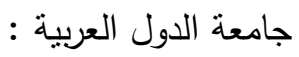
- م 199\%، التفكيـر الاسـتراتيجي والإدارة الإسـتراتيجية مـنهج تطبيقي ، الـدار

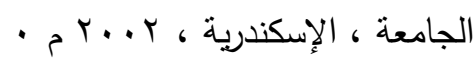
جمسال الدين محمـ المرسـي ومصـفى -

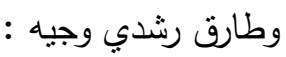

دور الدولـة في الاقتصـاد، مكتبـة الأسرة، الأعمـال الفكريـة، الهيئة

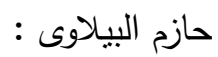

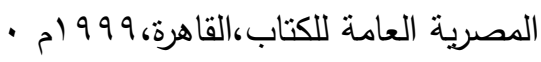

اقتصاديات الاتحادات الرياضية الاولمبية المصرية، دراسـة تحليلية ،

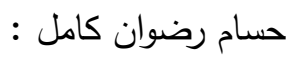
رسالة دكتوراه ، كلية التربية الرياضية للبنين ، جامعة حلوان

نظـام مشـروعات - البنـاء - الملكيـة - التشـغيل ونقل الملكيـة في

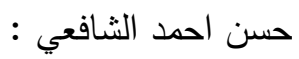

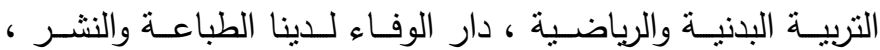

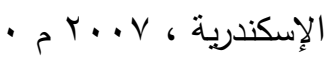

الخصخصـة الإدارية والقانونية في التربية البدنيـة والرياضية، مكتبـة

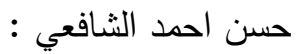

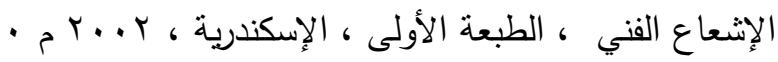
خصخصـة التعليم العربي في القرن الحادي والعشرين ( التحديات

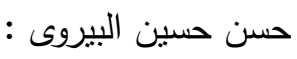
والاستجابات ) ، ورقة مقدمة إلى مؤتمر خصخصة التعليم العالي والجامعي ، كلية التربية ، جامعة السلطان قابوس ، . . بام . الجات - الخصخصة ،الكيانات الاقتصادية الكبرى ، التكاثز البشرى ، 
والرفاهية مشكلات اقتصادية معاصرة ،دار الكتاب الحديث ، ... بم

عرض عام لمشاكل تحويل الرياضة وتسويق الرياضة في الولايات

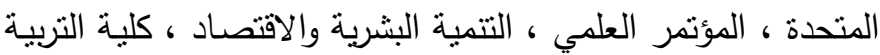

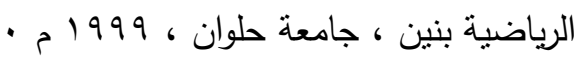

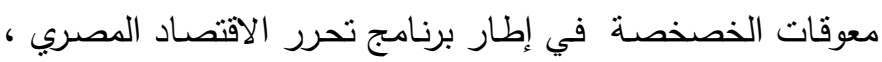

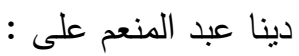

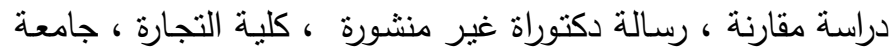

التجربة البريطانية فى الخصخصـة الدروس المستفادة ، مجلة كلية رزي على سلامة : - مزي

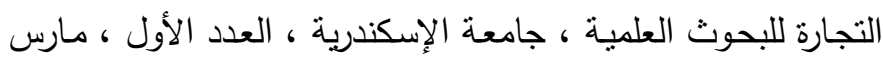
. 1994

الخصخصــة والتحـولات الاقتصــادية ،مركـز المحروســة للبحـوث

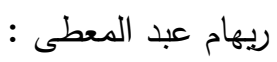

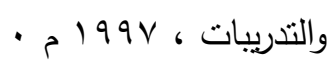

الآثار الاقتصادية لخصخصة بنوك القطاع العام فى مصر ، دراسة

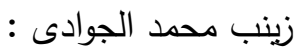
مقارنة للبنك الأهلي المصري والبنك التجاري الدولي ، رسالة دكتورة $-V$

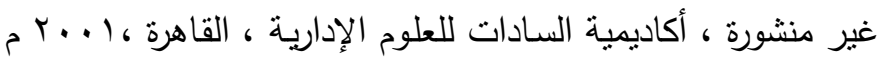

الخبرة الدولية في الخصخصة ، دار العلم للطباعة، ؟99 199 م .

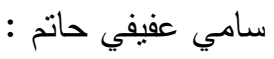

أسس إدارة التسويق الرياضي ،المكتبة العصرية،المنصورة، م. r م

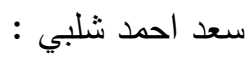

التخصية والتصحيحات الهيكلية في البلاد العربية ، صندوق النقد

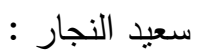

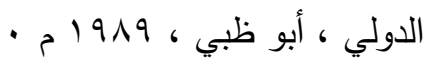
إدارة العيئـات الرياضـية - النظريـات الحديثـة وتطبيقاتها ، منثـاة

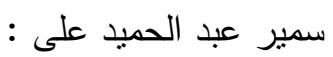

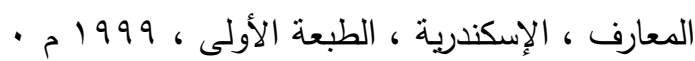

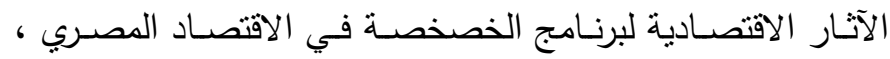

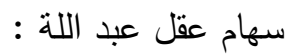

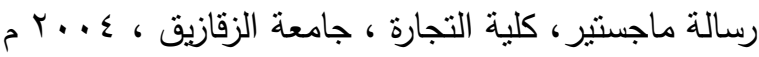
$-r$

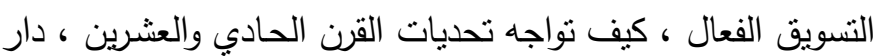
طلعت اسعد عبد الحمبد 


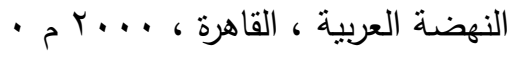

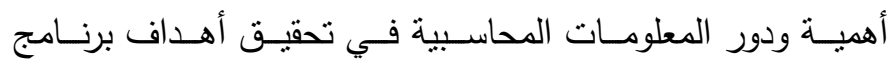
الخصخصــة في المملكـة العربيـة السـودية ، مجلـة كليـة التجـارة للبحوث العلمية ، المجلد الخامس والثلاثون ، العدد الثاني ، 1991

روية القطاع الخاص في الخصخصة ، مركز ابن خلدون للاراسات الاقتصادية والإنسانية ، دار سعاد الصباح ، الكويت ، 991 19 م. نموذج مقترح للتمويل الذاتي ، للهيئات الرباضية الاولمبية في مصر ، رسـالة ماجسـتير غيـر منشـورة ، كليـة التربيـة الرياضـية للبنـات

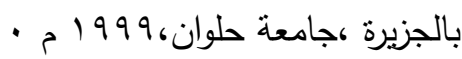

الخصخصة ، طباعة أبناء رياض سلامة ، إسكندرية ، . . . ب م. م.

إسـتراتيجية الخصخصـة في العـالم وتوجهاتهـا في دولـة الإمـارات العربية المتحدة ، الطبعة الأولى ، أكتوبر 991 م م الخصخصـة المقارنـة ، التجـارب والنجـاح ، إطلالــة على التجربـة المصرية ، مؤتمر دور المحاسبة والمراجعة في مرحلة الخصخصة ، - 1997 خصخصة مشروعات البنية الأساسية ، المتطلبات والبدائل والخبرات

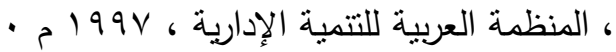

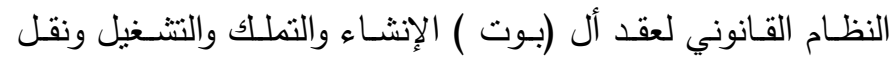
الملكية ، رسالة دكتوراة ، كلية الحقوق ، جامعة الزقازيق ، ع . . F م التقريـر النهائي للجنـة الثـئون الماليـة والاقتصـادية عـن الإصـالاح الاقتصـادي والاجتمـاعي في مصر لتقييم المرحلتين الأولى والثانية

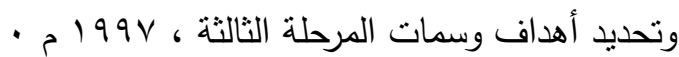
دور الإفصاح المحاسبي في عملية الخصخصة ، عدد خاص عن مـؤتمر الخصخصـة نقل التكنولوجيـة في مصـر مجلـة كليـة التجـارة للبحوث العلمية ، جامعة الإسكندرية ، مايو س99 19 م م الخصخصـة روبـة شخصية ، كليـة التجـارة ، جامعـة الإسكندرية ،$$
\text { عبد العال بن هاشم : n - n }
$$

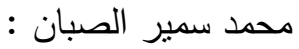

عبد الهادي تربحيب الثهرانى : : عمرو احمد مصطفى عوض شفيق عوض غرفة تجارة وصناعة أبو ظبي :

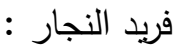

كريستين كسيندر ، تعريب : منير إبراهيم

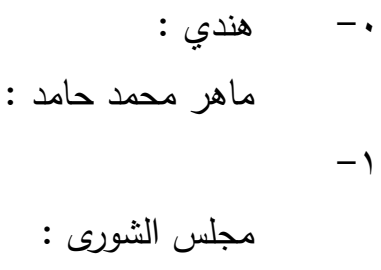
محمد صالح الحناوى : (2) 


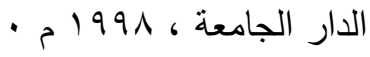

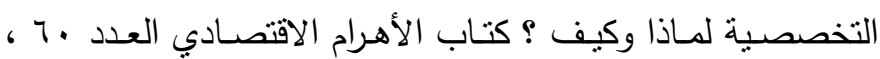

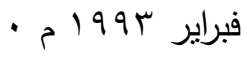

مشاكل التحول من القطاع العام إلى القطاع الخاص ، مؤتمر العلوم الإدارية ، نحو أفاق في العلوم الإدارية ، جامعة الملك فهد، 1991

الخصخصة ، ماذا ؟ منتى ؟ لماذا ؟ كيف ؟ المشكلات والحلول ؟

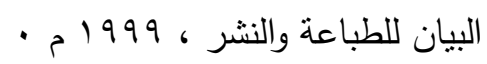

لائحسة القواعد الماليـة لإدارة وتشـغيل المنشـات الرياضـية وملحقاتها

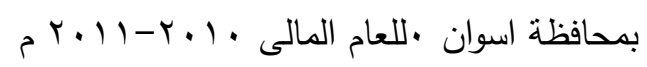

التقرير السنوي لإيرادات ومصروفات المنشـات الرياضية وملحقاتها

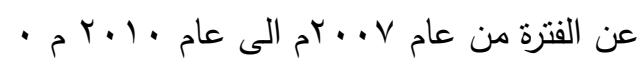

تحديث الرياضة المصرية ، ملحق مجلة الرياضة المصرية ، القاهرة

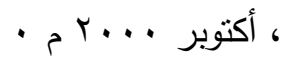

سيكولوجية الأداء الرياضي ، مركز الكتاب للنشر ، الطبعة الثانية ،

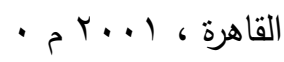

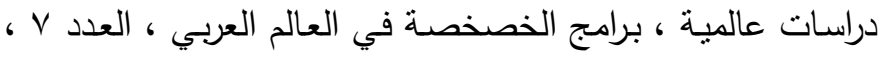
- 1991

تطـور الاسـتثمار الخـاص في مصـر في ثلاتـة فتـرات تاريخيـة ، المؤتثر السـنوي الثالث عشـر للاقتصـاديين المصـربين ، القـاهرة ، - 1911

تقرير بخصوص تجربة الكهرباء فئ المشروعات المنفذة بنظام (B مقدم إلى الندوة العلميبة الأولى ، أكاديميـة

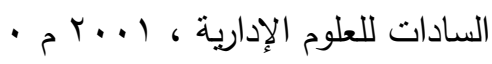

الجوانب القانونيـة للخصخصـة ، مجلـة الحقوق ، جامعـة الكويت ، العـدد ، العـدد الرابـع ، السـنة التاسـعة عثـر، الكوبــ ، ديسـمبر معتز كامل المرسى : - معى

: محمد صديق عفيفي

: محمد صفوت قابل :

: محمود صبح

مديرية الثباب والرياضة :

مديرية الثباب والرياضة :

مسعد سيد عويس :

مصطفى حسين باهى

1- ومحمد منولي عفيفي :

مركــز الإمــارات للاراســات وللبحــوث

: الإستراتيجية

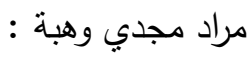

r

مهدي إسماعيل الجزاف :

$-0$ 
أسـاليب وطرق خصخصـة المشـروعات العامـة ، خلاصـة الخبرات

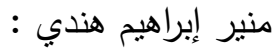

العالميــة ، المنظمــة العالميـة للتتميـة الإداريــة ، إدارة البحـــوث

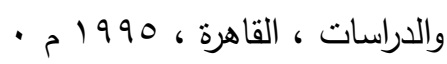

الآثـار الاجتماعيـة للخصخصــة علـى العـاملين فـي المنشـات

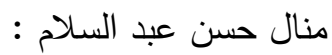
الاقتصادية ، دراسة تطبيقية ، رسالة دكتوراه ، كلية الآداب ، جامعة الآل

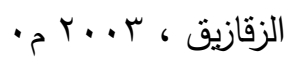

خصخصة مراكز الثباب بمحافظة الإسكندرية إستراتيجية مقترحة ،

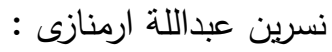

رسالة ماجستير ، كلية التربية الرياضية للبنات ، جامعة الإسكندرية

John D0donahue :

Kazimierz Perechuda

Megginson Leon :

$-1$

$$
\text { Tesng - ji - Shou : }
$$$$
-r
$$

Thomas F Custafson
The Privatization Decision Public Ends, A Division Of Harper Collins Publisher U.S.A 1989 . Restructuring and privatization of sports organizations, 2002

Donalp Mosley and paul pietri Management corcepts And Applications ( New York ), Harper Collins,1992 Economic reformin chia ,A Privatization model for tate , owned enterprises golden gate university ,1998 . Privatization and Its effect on Public Golf, Employee Daniel D Mclean , Ph . D October , 2002

$$
\text { ثالثا : شبكة المعلومات الدولية }
$$

www.ahram.org.eg/Archive/2006/9/20 


\section{ملخص البحث}

تصور مقترح لإدارة الأندية الرياضية بنظام الخصخصة الجزئية بمحافظة أسوان

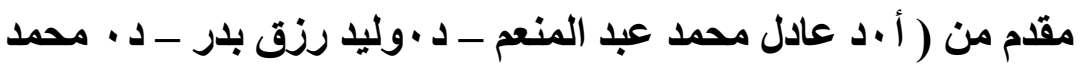

عنوان البحث:

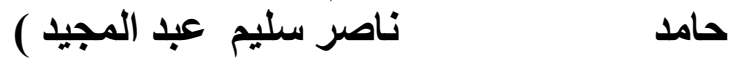

يهدف البحث إلى وضع تصور مقترح لإدارة الأندية الرياضية بنظام

الخصخصة الجزئية بمحافظة أسوان وذلك من خلال :-

هدف البحث : - التعرف على الوضع الحالي لإدارة الاندية الرياضية بمحافظة

أسوان

r- وضع تصور مقترح لإدارة الاندية الرياضية بنظام الخصخصة الجزئية

بمحافظة أسوان

1-ما الوضع الحالي لإدارة الاندية الرياضية بمحافظة أسوان ؟

تساؤلات البحث

r- ما التصور المقترح لإدارة الاندية الرياضية بنظام الخصخصة الجزئية

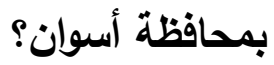

قام الباحث باستخدام المنهج الوصفي " الاراسات المسحية وذلك لمناسبته لطبيعة البحث

منهج البحث :

اختار الباحث مجتمع البحث من مديري الاندية الرياضية ومديري النشاط الرياضي ورئيس وامين صندوق الاندية الرياضية ، بلغ عدد عينة

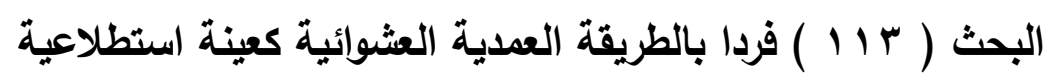
مجتمع وعينة البحث وعينة أساسية إلى ثلاثة مجموعات عينة الوضع الراهن

بلغ عدد عينة الوضع الراهن ( . ) فردا بالطريقة العشوائية كعينة

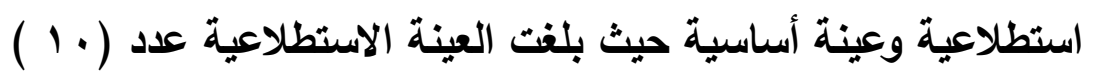


أفراد من مديري الاندية الرياضية ومديري النشاط الرياضي ورئيس وامين صندوق الاندية الرياضية بأسوان

وقسمت العينة الأساسية والتي بلغت عدد ( •. ) فردا إلى ثلاثة

مجموعات : - ماتهي

• تطبيق المشروع المقترح لإدارة الاندية الرياضية بنظام الخصخصة

• الجزئية بمحافظة أسوان

• العمل على وضع إستراتيجية طويلة الأجل تمثل الإطار الأي يتولى رسم

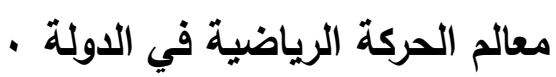

• التأكد عل ضرورة أن ترسخ المؤسسات الرياضية الفكر الاقتصادي التوصيات المطروح الواعي بأهمية الرياضة وممارستها وتثنيع المواطنين على الاخول في تنميتها وتطويرها - الدي

• إعادة هيكلة المنظومة الرياضية على أساس مفهوم التحديث والتطوير • التأكد على أن خصخصة الاندية الرياضية . • دعم وتعزيز التوجه نحو الخصخصة لأهداف إستراتيجية . 